\title{
A direção espiritual católica e a sua influência no desenvolvimento da espiritualidade feminina
}

\section{Catholic spiritual direction and its influence on the development of women's spirituality}

DOI: $10.46814 / \operatorname{lajdv} 3 n 6-030$

Recebimento dos originais: 01/11/2021

Aceitação para publicação: 20/12/2021

\section{Rosa Maria Guimarães Bastos Ferreira de Souza}

Master en Matrimonio y Família - Universidade de Navarra - Espanha (2004)

Mestrado em Teologia - PUC-PR (2011)

Instituição de atuação atual: Aposentada com trabalhos voluntários.

Endereço completo: Rua Mauá 719, apto 802-B, Curitiba-PR-Brasil

E-mail: rosa@pinho.com.br

\section{RESUMO}

O estudo do processo que constitui a direção espiritual como uma das mediações favoráveis para o amadurecimento na fé e o crescimento humano-cristão constitui o objeto da presente pesquisa. A direção espiritual foi definida - na história da espiritualidade - como a ciência e a arte com a qual um adulto ajuda outro no caminho do discernimento pessoal e na resposta ao Espírito Santo rumo à santificação. Assim, nas diversas etapas da vida, a direção espiritual aparece como um dos instrumentos para o crescimento espiritual do cristão que está chamado à plenitude da vida cristã (LG, V). O objetivo desta pesquisa, portanto, consiste em evidenciar a rica tradição católica da direção espiritual e investigar a influência destana atualidade e, em particular, na vida de um grupo de mulheres católicas que vivem na cidade de Curitiba, Paraná/BR. Desse modo, na primeira parte do trabalho, apresentamos os dados da história: desde a função propedêutica de guia eacompanhante exercido pelas grandes figuras bíblicas, passando pelo período monástico, até chegar às reflexões contemporâneas. Indicam-se, por sua vez, as relações e as diferenças da direção espiritual com a psicoterapia. Já a segunda parte do trabalho traz os resultados da pesquisa de campo, realizada por meio de entrevistas com nove mulheres que foram e estão sendo acompanhadas por um diretor/a espiritual por mais de cinco anos. Para essa pesquisa optamos pela metodologia qualitativa do tipo exploratória analítica, por meio da análise dos discursos, envolvendo cinco procedimentos básicos fundamentais: identificação do fenômeno, estruturação do estudo, organização dos dados, análise dos dados e apresentação dos resultados. As atividades de pesquisa dessa abordagem refletem as crenças a respeito da importância do contexto, explorando todas as dimensõesda singularidade humana e ajudando a entender o sentido da experiência vivida por cada uma das mulheres investigadas à medida que essas pessoas interagem no cenário social em resposta às circunstâncias da vida. Os resultados da análise dos discursos dos sujeitos revelam que tais mulheres, de um modo geral, desde que iniciaram a sua direção espiritual, afirmam terem se tornado pessoas mais maduras e equilibradas emocionalmente, sentindo-se mais seguras, confiantes e próximas deDeus. Evidencia-se, contudo, que a direção espiritual regular traz alguns benefícios práticos que ajudam a incrementar a qualidade de vida das pessoas que recebem essa orientação e, ao mesmo tempo, conforme testemunham os depoimentos, há também uma repercussão positiva na convivência com outras pessoas, sobretudono ambiente familiar.

Palavras-chave: Direção Espiritual, Desenvolvimento, Espiritualidade feminina. 


\begin{abstract}
The study of spiritual guidance as a favorable mediation process for the human- Christian development and maturation of faith is the subject of this research. Spiritualguidance has been defined - throughout the history of spirituality - as the science and art with which one adult aids another on his path of personal judgment and onhis course to sanctification. Spiritual guidance is an instrument for the spiritualdevelopment on course to the plenitude of the Christian Life throughout the many stages in life (LG, V). This research highlights the rich Catholic tradition and investigates the influence of spiritual guidance on the modern days, through the observation of a group of women living in the city of Curitiba, Paraná, BR. The first part of this study presents historic events from the leadership of great biblical figures,through the monastic period and all the way up to the modern days, analyzing the similarities and differences between spiritual guidance and psychotherapy. The second part of this study describes the results of the field study with interviews among nine adult women who have been guided by a spiritual director for periods over five years. An exploratory qualitative research method was employed for this research through a speech analysis composed of five fundamental principles: phenomenon identification, study structuring, data organization, data analysis and presentation of the results. The activities of this research explore all the dimensions of the human singularity attempting to understand the meaning of the life experiences as these women interact within the social context in response to the circumstances of their lives. The results of the speech analysis reveal that these women, after undergoing spiritual guidance, admit to having become more mature and emotionally balanced, more confident and secure, and living a more intimate relationship with God. The study makes evident that regular spiritual guidance brings practical benefits that support the life quality development of those subject to such orientation, as well as substantially positive effects on social relationships, especially within their homes and families.
\end{abstract}

Key words: Spiritual Guidance, Development, Female Spirituality.

\title{
1 INTRODUÇÃO
}

A direção espiritual foi definida na história da espiritualidade, como a ciência e a artecom a qual uma pessoa adulta ajuda outra no caminho rumo à santificação. Sendo assim, o objeto desta pesquisa consiste no estudo do processo que constitui a direção espiritual como uma das mediações favoráveis para o amadurecimento nafé e o crescimento humano-cristão. O objetivo deste trabalho consiste, portanto, em examinar os benefícios desta prática milenar da Igreja, e analisar a sua influência nos dias atuais, especialmente, na vida de um grupo de mulheres católicas que vivem na cidade de Curitiba, Paraná/BR.

A princípio, talvez possa parecer estranho uma pessoa com formação em psicologia se interessar por assuntos religiosos. Isto porque, de um modo geral, o psicólogo, e a grande maioria das escolas de psicologia, principalmente no Brasil, sofrem a influência - de uma maneira ou de outra - das ideias tradicionais da psicanálise e suas ramificações. Freud costumava descrever a religião como uma ilusão, sustentada apenas para satisfazer algumas necessidades psicológicas naturais. A crença religiosa, segundo ele, vinha associada, desde os primeiros momentos, aos estudos da neurose histérica. 
Nela, a dissociação ${ }^{2}$ da consciência manifesta o processo que os psicanalistas denominam perversão da vontade (FRANKL, 1964).

Viktor Emil Frankl, psiquiatra austríaco e contemporâneo de Freud, tinha uma outra perspectiva a esse respeito. Com uma concepção diferente da de Freud $^{3}$ ou a de Adler $^{4}$ - os dois grandes expoentes em voga na Viena abalada pela Guerra naquela época -, o sistema e o pensamento de Viktor Frankl se articula em torno de três noções básicas fundamentais: logoterapia ${ }^{5}$, análise existencial e cura médica de $a \operatorname{lmas}^{6}$. Aqui, de uma medicina exclusivamente científica, surge uma abordagem com uma perspectiva profundamente humana.

Apoiado em uma vasta experiência clínica e os sofrimentos que viveu como prisioneiro no campo de concentração Dachau em Auschwitz, durante a Segunda Grande Guerra, o doutor Frankl (2003), oferece uma perspectiva nova, enfatizandoo espiritual como a dimensão genuinamente humana, da qual, segundo ele, não se pode prescindir na prática psicoterapêutica.

A análise existencial de Frankl explica a existência do homem desde a sua tridimensionalidade ontológica, transcendendo o meramente temporal ou psicofísico e atingindo à dimensão noológica do ser humano. Benigno Freire (2002a, p. 58), considerando a esse respeito, explica que "só se pode compreender a unidade antropológica do homem a partir da diversidade ontológica do corporal, do psíquicoe do espiritual". O mesmo Freire (2002a, p. 59) continua, afirmando que "o homem éuma unidade-totalidade que se manifesta na conduta como a conjunção das três dimensões - espiritual, psíquica e biológica -, indivisivelmente entrelaçadas”.

Foi a partir da percepção dessa concepção antropológica, que nasceu a motivação para realização deste trabalho. Com a proposta de ajudar nacompreensão da multiplicidade de aspectos envolvidos no desenvolvimento da espiritualidade feminina, colocando em evidência o papel da direção espiritual no cenário dos dias atuais.

Com esse objetivo, e partindo-se de algumas observações ${ }^{7}$ preliminares, pôde-se perceber que um grupo de mulheres orientadas por um diretor espiritual com uma certa regularidade, apresentavam determinadas característicasespecificas em comum que as destacavam, de uma maneira geral, como pessoas maduras $^{8}$ e equilibradas emocionalmente. Amatuzzi (2008, p. 15) explica que isso acontece com frequência quando algumas pessoas são capazes de vivenciar uma espiritualidade amadurecida, "fomentando a integração do humano que a experiência religiosa promove, como pólo integrador e dinamizador de uma auto- transcendência”.

A partir dessas constatações, a pesquisa aconteceu em três etapas. A primeira baseada em um estudo documental e bibliográfico apresentando uma visão geral da história do acompanhamento espiritual ao longo dos séculos. Iniciando coma revelação bíblica e os primórdios do Cristianismo, passando pelo período do início da vida monástica oriental e ocidental, seguindo com a Idade Média 
(Séc. VI-XV) e Moderna (Séc. XVI-XIX), continuando no "século de ouro" da espiritualidade na Espanha e concluindo com os desafios da direção espiritual no mundo moderno. Na segunda parte, apresentamos a interação entre psicologia e espiritualidade, procurando-se estabelecer a correlação e, principalmente, a diferenciação entre psicoterapia e direção espiritual.

Finalmente, na última etapa, apresentamos o desenvolvimento da pesquisa propriamente dita. Optamos pela metodologia de pesquisa qualitativa do tipo exploratória analítica, baseada em autores como Fiorin, Minayo, Lane, Caregnato Savioli e Car; Bertolozzi, envolvendo cinco procedimentos básicos fundamentais: identificação do fenômeno; estruturação do estudo; organização dos dados; análise dos dados e apresentação dos resultados.

Os resultados da análise dos discursos dos sujeitos investigados, evidenciaram que tais mulheres, desde que iniciaram a sua direção espiritual, afirmam terem se tornado pessoas mais maduras, com a aquisição de algumas virtudes fundamentais, ajudando-as a se tornarem mais equilibradas emocionalmente, sentindo-se, de uma maneira geral, mais tranquilas, seguras, e principalmente, mais confiantes e próximas de Deus. Verificou-se, contudo, que a direção espiritual regular traz alguns benefícios práticos que ajudam a incrementar aqualidade de vida das pessoas que recebem essa orientação e, ao mesmo tempo, tem um reflexo positivo também na convivência com outras pessoas, especialmente,com o marido, filhos e parentes mais próximos.

Essa pesquisa foi submetida e autorizada pelo Comitê de Ética em Pesquisa

- CEP/PUC-PR - conforme protocolo n. 5722, de 14 de Setembro de 2010. Seguindo-se as diretrizes e normas regulamentadoras de pesquisas envolvendo seres humanos, da Resolução 196/96 do Conselho Nacional de Saúde9.

\section{REFERÊNCIAS HISTÓRICAS DA PRÁTICA DA DIREÇAO ESPIRITUAL}

Antes de abordarmos o estudo sistemático da direção espiritual através dos séculos,parece oportuno examinarmos, brevemente, os princípios fundamentais da espiritualidade cristã transmitida, no início, diretamente por Jesus Cristo e, mais tarde, difundida pelos seus apóstolos.

A espiritualidade cristã está integralmente fundamenta na doutrina de Jesus. Não existe outra espiritualidade legitima e autenticamente cristã. São Paulo declara expressamente: "ninguém pode pôr outro fundamento diferente daquele que está assente: Jesus Cristo" (1 Cor 3, 11). Da mesma forma São Pedro afirma que Ele (Cristo), é a pedra angular: "Em nenhum outro está a salvação; pois não há, debaixodo céu, outro nome dado aos homens pelo qual devamos ser salvos" (At 4,12).

A história da espiritualidade cristã é uma história de amor: a história do Amor de Deus pelos homens e dos homens por Deus. Esta é a primeira ideia que deveser compreendida por aqueles que pretendem se aprofundar nos temas relacionados à direção espiritual. 
Sistematicamente, procura-se neste capítulo, apresentar algumas fontes históricas que foram deixadas por pessoas, instituições, acontecimentos, escritos, etc., que parecem ser relevantes quando se trata de assuntos envolvendo a direção espiritual. Este caminho nos conduziu, principalmente, às vidas, experiências e preclaros ensinamentos de alguns homens e mulheres, grandes mestres espirituais, pessoas iluminadas, que pela sua importância histórica e modelo de vida, merecem ser considerados quando pretende-se examinar as formas e modelos que a direção espiritual tem adotado ao longo dos séculos.

\subsection{NA REVELAÇÃO BÍBLICA}

Com reiterada insistência, através dos textos da Sagrada Escritura, encontramos Deus que se revela ao homem, conduzindo e guiando a todos pelos caminhos que levam à salvação.

Podemos encontrar um fundamento bíblico da prática da direção espiritualem todos os convites dirigidos por meio da Palavra às várias categorias de pessoas, sobretudo nos livros sapienciais e proféticos. Deus dirige-se aos inexperientes (jovens), aos fracos, aos simples e néscios (a quem falta sabedoria), e a todos os que necessitam ser orientados e encaminhados pelas indicações e inspirações do Espírito Santo: "O que será de alguém que cai sem ter um companheiro para levantálo?” (Ecl 4, 10); “O homem sensato não despreza os conselhos [...]. Não faças nada sem conselho: não te arrependeras de teu atos" (Eclo 32, 18-19); "Buscai o conselho de toda pessoa sensata, e não desprezes nenhum conselho salutar" (Tb 4, 18). No livro do Eclesiástico, inclusive, encontramos uma recomendação definitiva para se buscar um conselheiro confiável: "Dirige-te sempre a um homem piedoso, que tu conheces por observar os mandamentos, que tem a alma conforme a tua e que se tropeçares, sofrerá contigo" (Eclo 37, 12).

Essas passagens nos servem como exemplos de algumas valiosas indicações que dão sentindo e fundamentação à prática da direção espiritual adotada desde sempre na vida da Igreja.

\subsection{NOS PRIMÓRDIOS DO CRISTIANISMO}

A vida dos primeiros cristãos tem uma especial importância na história da espiritualidade, justamente pela proximidade e a experiência real que estas pessoasviveram junto a Jesus Cristo, a Virgem Maria e os Apóstolos. Havia entre eles, uma clara consciência da realidade e das exigências para a santidade. Não era concebida a ideia de se viver o Cristianismo pela metade. Aquelas pessoas viviam manifestando a sua fé integralmente, em todos os ambientes e situações da vida: nafamília, no trabalho, no descanso, etc.

A moral e a espiritualidade cristã incluía a valorização de algumas virtudespara muitos desconhecidas até então. A forma de viver a castidade (tantomatrimonial como virginal), a 
temperança, a fortaleza (chegando, algumas vezes, ao heroísmo do martírio), a justiça, e principalmente, a caridade, ou o amor, como aprimeira virtude cristã, era uma característica marcante dos cristãos daquela época.Além de viverem plenamente as exigências de integridade moral, aquelas pessoasviviam exemplarmente, amado-se uns aos outros e ajudando-se mutuamente, o queimplicava a prática da direção espiritual dos mais velhos orientando os mais novos.Em várias passagens do Evangelho encontramos o Senhor, o Bom Pastor,

que conhece individualmente as suas ovelhas, e as ovelhas o conhecem, o escutame o seguem (Jo 10, 14). Podemos observar Jesus dialogando constantemente com seus discípulos e os dirigindo com carinho durante a sua vida pública, até depois da sua Ressurreição. Além disso, encontramos Jesus conversando pessoalmente com Nicodemos e dissipando as suas dúvidas (Jo 3, 1-21); com a mulher samaritana, a qual Ele se manifesta como Messias (Jo 4, 7-25); e também com o publicano Zaqueu, que se converte após o encontro com o Mestre (Lc 19, 2-10). Outroexemplo de Jesus orientando a seus discípulos é o que acontece no caminho de Emaús, enquanto os discípulos conversavam, "Disseram um ao outro: Não ardia o nosso coração quando ele nos falava pelo caminho, quando nos explicava asEscrituras?” (Lc 24, 32). Nessas passagens evangélicas pode-se perceberclaramente como o Mestre acolhe, escuta atentamente, orienta e instrui pacientemente a seus discípulos. Essas são as atitudes que devem ser observadas e que fazem parte das características de todo bom diretor espiritual.

Nos Atos do Apóstolos encontramos alguns episódios nos quais tradicionalmente se apóiam a prática da direção espiritual. Por exemplo, com São Paulo recém-convertido, quando se dirigia a Damasco, depois de cair do cavalo, o Senhor lhe ordena que se apresente a Ananias para saber o que devia fazer (At 9, 6-19). E para São Pedro, foi o centurião Cornélio quem Deus lhe enviou para o auxiliar no início da sua evangelização na Cesaréia (At 10).

Com o mesmo objetivo, recordando o intenso ministério que havia realizado em Tessalônica, São Paulo enfatiza a atenção especial que dedicou a cada um dos cristãos: "Bem sabeis que exortamos a cada um de vós como um pai a seus filhos; nós vos exortamos, vos encorajávamos e vos conjurávamos a viver de maneira digna de Deus, que vos chama ao seu Reino e à sua glória” (1Ts 11-12). E também, aos anciãos de Éfeso, ele orientava com carinho: "Vigiais, portanto, lembrados de que, durante três anos, dia e noite, não cessei de exortar com lágrimas a cada umde vós em especial" (At 20, 31).

O diretor espiritual é, portanto, esse guia cauteloso e paciente, aquele que conhece melhor o caminho. Alguém que com a sua experiência e exemplo de vida écapaz de encaminhar, iluminado pelo Espírito Santo, orientando e conduzindo pelos caminhos que levam a Deus. Essa é exatamente a tarefa do guia espiritual: 
Aconselhar com base na realidade; orientando às pessoas que a ele se confiam, com a sua ciência e a sua experiência pelos autênticos caminhos que levam a Deus; promovendo o amadurecimento na fé, uma fé segura, explicita e atuante; favorecendo esse desenvolvimento com os meios humanos naturais, e também os sobrenaturais. O importante é utilizá-los para os dinamismos próprios da pessoa e das situações particulares em que ela se encontra (MERCATAZI. In.: FIORES; GOFFI, 1989, p. 872).

\subsection{NO COMEÇO DA VIDA MONÁSTICA ORIENTAL}

Apesar da direção espiritual aparecer sempre presente, desde o inícioda era cristã, são nos documentos relacionados com o monacato primitivo onde encontraremos as primeiras evidências históricas de alguns modelos estáveis de uma ajuda espiritual sistemática.

Segundo os primeiros monges, a principal qualidade ou característica básica de um diretor espiritual é, precisamente, o fato de ser espiritual, ou seja, de possuiro Espírito Santo e agir de acordo com o impulso e as inspirações do Paráclito.

Naquele tempo, independentemente do sacramento da Confissão, os monges costumavam buscar os conselhos de um diretor espiritual, que naquela época era designado com o termo $a b b a$ (pai), que normalmente não eram sacerdotes, porque nem os anacoretas, nem mais tarde os abades dos cenóbios, eram geralmente presbíteros. No caso da vida cenobítica, de acordo com Sesé (2005), o pai (diretor) espiritual habitualmente era o próprio abade ou hêgoúmenos (o que guia), ou algum de seus assistentes que o mesmo abade designava para esta missão. Por sua vez, os anacoretas escolhiam o seu pai espiritual entre os monges que fossem de sua inteira confiança, considerando-se que a vida anacorética consistiafundamentalmente em submeter-se a um guia, um mestre experiente que era escolhido livremente pelo próprio discípulo.

O objeto da direção espiritual no monacato primitivo era a exagóreusis tôn logismôn, a revelação ou declaração dos pensamentos. O que era indispensável manifestar na direção espiritual não eram os pecados, mas sim os logismoi, os pensamentos que perturbam a paz da alma.

Ainda de acordo com Sesé (2005), na psicologia dos monges do deserto se distinguiam três fases na tentação. A primeira é a prosbolê, ou ataque da tentação, na qual não há responsabilidade por parte do indivíduo tentado. Depois acontece o syndasmós ou colóquio interior. Em seguida se dá a pálê ou luta contra a tentação, que pode acabar com a vitoria ou com a sygkatáthesis e a aprovação ou o consentimento do pecado. A direção espiritual se encarregava de tratar a primeira fase da tentação.

A pessoa que se dirigia ao pai ou diretor espiritual deveria ter anteriormente feito a chamada nepsis (atenção), que é um exame de consciência para discernir a bondade ou a maldade dos próprios pensamentos. Royo-Marín (1990) ressalta que,além de ser espiritual, o guia das almas deve possuir o 
dom da diakrisis, que significa, ao mesmo tempo, discrição, ponderação e discernimento. De acordo com este mesmo autor, também as monjas podiam ser mães (ammas) espirituais de outras monjas.

\subsection{NO INÍCIO DA VIDA MONÁSTICA OCIDENTAL}

A obra de João Cassiano, desempenhou um papel decisivo no desenvolvimento da espiritualidade ocidental. Esse grande teólogo cristão apresentaem duas grandes obras - Instituições e Conferências -, a experiência monástica oriental, adaptando-a à mentalidade da vida ocidental. Essas obras tratam abundantemente da direção espiritual, insistindo na necessidade de sua prática para alcançar-se a plenitude e a santidade:

Aquele que segue a sua inspiração pessoal e se fia demasiadamente no seu próprio juízo, nunca poderá alcançar os cumes da perfeição. É impossível que não sucumba às perigosas ilusões pelas quais conspira o demônio [...] Ninguém esta autorizado, por mais sábio que seja, a acreditar que poderá prescindir dos conselhos de um irmão. As ilusões de Satanás o levaram ao engano e ele não escapará dos laços que estará atado pela presunção da soberba (Conferências II, 16. In.: CASSIANO, 2003).

Foi principalmente através da doutrina espiritual desse grande mestre, que aspráticas e os ensinamentos a respeito da vida ascética - e em seguida, sobre o monaquismo cristão -, nos quatro primeiros séculos, foram transmitidos do Oriente para o Ocidente. Através da leitura dessas grandes obras de Cassiano - nos mosteiros e posteriormente nos ensinamentos dos abades e dos escritos de muitos mestres e doutores da Igreja -, que progressivamente foi desenvolvida uma verdadeira Teologia da vida espiritual, não apenas nos aspectos práticos, ascéticos, mas também em sua dimensão mais profunda, que mais tarde se denominaria de experiência mística.

Foram muitos e sábios os ensinamentos desse grande mestre a respeito da necessidade e importância da direção espiritual. Na Primeira Conferência do Abade Moisés, Cassiano (Conferências I, 20. In.: CASSIANO, 2003), insiste que “em primeiro lugar, com o máximo cuidado, devemos examinar tudo quanto se insinue sorrateiramente em nosso coração [...] É o que nos compete fazer, se obedecemosa palavra Apóstolo: Não acrediteis em qualquer espírito, mas examinai os espíritos para saber se são de Deus (1 Jo 4, 1)".

Continuando, Cassiano sublinha a importância da sinceridade do dirigidodurante a direção espiritual:

Rasgando o véu com que a falsa vergonha queira cobri-los, manifestemos aos mais experientes, todos os segredos de nossa alma, e caminhemos com confiança, buscando com esses mestres, o remédio para nossas feridas e o exemplo de uma vida santa (Conferências II, 16. In.: CASSIANO, 2003). 
Assim também São Basílio, no século IV, recomendava intensamente e explicava sobre necessidade do acompanhamento espiritual:

Ponde sempre a maior diligência e a maior atenção em encontraruma pessoa que vos possa servir de guia seguro na tarefa quequiserdes empreender para alcançar uma vida santa; escolhei alguém que saiba indicar às almas de boa vontade pelos verdadeiros caminho que conduzem a Deus (SPINELLI, 2002, p. 89).

Para dar à vida monástica comunitária na Igreja Bizantina sua configuração final, o mérito maior cabe a Basílio Magno (330-379). Seus escritos ascéticos, que originariamente foram destinados aos monges da Capadócia, continuam as motivações pedagógicas e teológicas da vida comum dos monges, o cenobitismo. Foi ele quem criou a regra monástica que em sempre novas variações e modalidades veio a tornar-se a base do monaquismo ortodoxo.

\subsection{NA IDADE MÉDIA}

Os primeiros séculos da Idade Média assinalam uma severa decadência na vida da Igreja, assim como nos costumes cristãos. Foram tempos difíceis e confusos. Entretanto, neste período, acontecia uma notável reviravolta na vida religiosa e no desenvolvimento moral e intelectual das pessoas dentro dos monastérios. Nessa época, começam a surgir as diversas escolas de espiritualidadeem torno das grandes ordens religiosas. E com isso, o aparecimento de algumas figuras importantes, padres e madres espirituais, que se destacaram como mestres,naquela época de turbulência, compreendida entre os séculos VI e XV da era cristã.

\subsubsection{A escola de espiritualidade beneditina}

A ordem de São Bento, segundo Royo-Marín (1990), inspirada principalmentena liturgia e nas observâncias monásticas através da Regra, indicava naquela época (observada até hoje), alguns caminhos úteis para a orientação e o desenvolvimentoespiritual dentro dos mosteiros: a) A solidão e o silêncio; b) A obediência e a humildade; c) O Opus Dei, ou ofício divino, com o qual exerce-se o apostolado católico; d) A lição divina, pela qual o espírito se alimenta, se instrui e se prepara para a contemplação, que nasce da reflexão contínua da palavra de Deus; e finalmente, e) O trabalho manual, como um exercício físico e mental que enriquecea quem o pratica, ocupa a pessoa e a defende contra a ociosidade, mãe de todos osvícios. Esses preceitos eram largamente difundidos em todos os mosteiros beneditinos, passando dos mais experientes aos mais jovens por meio do acompanhamento espiritual.

Outras importantes figuras que se destacaram como grandes mestres espirituais entre os beneditinos, foram Santo Anselmo de Cantorbery e São Bernardo de Claraval, juntamente como um grupo de monjas escritoras beneditinas: Santa Hidelgarda (1098-1179), Santa Matilde de Magdeburgo 
(1212-1283), Santa Matilde de Hackeborn (1241-1299), Santa Gertrudis a Grande (1256-1301), e Santa Brígida da Suécia (1302-1373).

Santo Anselmo (1033-1109) foi um grande diretor espiritual, que deixou a suacontribuição em muitas monografias, opúsculos, homilias, meditações, orações e cartas, porém não chegou a redigir uma Suma sobre o conjunto da teologia. Ele ensinava com particular maestria a arte da oração e da meditação, deixando alguns modelos e considerações espirituais preciosas, precedidas de sábios conselhospara se tirar delas o máximo proveito. Suas meditações e cartas evidenciam seus dotes e a peculiar habilidade de um grande mestre e diretor espiritual, especialmente de monges.

São Bernardo de Claraval (1090-1153), é a figura mais destacada nesse período, exercendo uma enorme influência tanto na vida dos beneditinos como de toda Igreja. Ele deixou um legado riquíssimo desde o ponto de vista doutrinal, especialmente em suas obras oratórias conservadas em 330 sermões e 14 tratados sobre espiritualidade e orientação espiritual. Sua influência pode ser explicada pela variedade de temas que ele aborda e pela eloquiência e acerto como que os trata. Seus livros refletem claramente a profunda vida interior e a sua incansável atividade produtiva como mestre espiritual. Em seu opúsculo De consideratione ad Eugenium Papam, ele oferece valiosos conselhos a Eugenio III - que havia sido seu discípulo em Claraval e eleito Papa em 1145 -, tanto para sua vida espiritual como para o governo da Igreja no Séc. XII. Aqui São Bernardo enfatiza muito o dom do discernimento, qualidade que segundo ele, não pode faltar ao diretor espiritual.

Sobre a necessidade da direção espiritual, em sua carta a Ogerio, SãoBernardo faz a seguinte advertência:

Aquele que se constitui seu próprio mestre, escolhe para seu diretoro pior louco [...] Não sei o que pensam os outros de si mesmos sobreesse assunto; eu falo por experiência própria e, pelo que me diz respeito, digo que é mais fácil governar a muitas pessoas e dirigi-las do que governar e dirigir a mim mesmo (Carta 87, 7. In.: DÍEZ- RAMOS, 1953).

\subsubsection{A escola dominicana}

Quando se trata de apresentar as características fundamentais de uma determinada escola de espiritualidade, tem-se que tomar o cuidado de não pretender apresentá-la como uma concepção original, distinta ou separada das demais. Isto levaria a uma desorientação inicial e a um desconhecimento básico do que constitui a raiz e o fundamento de toda espiritualidade cristã.

De acordo com Royo-Marín (1990), por maiores que sejam as diferenças de enfoque com relação aos distintos meios de santificação, é evidente que todas as escolas de espiritualidade buscam o mesmo fim e aspiram ao mesmo ideal: a perfeição na caridade. Portanto, no que se refere ao básico e fundamental, as escolas de espiritualidade cristãs coincidem, obviamente, em absolutamente tudo. 
Entretanto, ao lado dessas coincidências fundamentais, é evidente que existem uma infinidade de matizes no enfoque e aplicação dos meios particulares de santificação.

A espiritualidade dominicana recebeu, desde o início, a forte e profunda influência de São Tomás de Aquino, orientada nitidamente à contemplação e ao apostolado: contemplata aliis tradere (Contemplar e dar aos demais o contemplado), é o lema da ordem. Essa é a comunicação, segundo Royo-Marín (1990, p. 220), quedeve acontecer por meio do apostolado e da direção espiritual: “O Dominicano deve ser um monge contemplativo que comunica aos demais, pelo apostolado da palavra e da pena, a verdade saboreada previamente no silêncio da contemplação”.

Santo Domingo de Guzmán (1170-1221) foi o fundador da ordem dominicana.De seus escritos se conservam apenas o Livro dos costumes - uma espécie de constituição da ordem -, as Constituições das monjas dominicanas de São Sixto de Roma, e uma Carta às monjas de Madrid. Entretanto, a sua vida que está relatada pelos seus primeiros discípulos proporcionaram informações suficientes para conhecer-se bastante sobre sua personalidade, seu espírito e o estilo que imprimiuà sua fundação.

A escola dominicana vincula a ascética e a mística aos dons do Espírito Santo. Seus teólogos, inclusive São Tomás de Aquino, expõem a doutrina espiritual quando tratam das virtudes infusas e dos dons do Espírito Santo, principalmente o dom da sabedoria, o que produz, segundo suas explicações, os estados sobrenaturais (êxtase místico).

\subsubsection{A «cura animarum» das ordens mendicantes}

No início do século XIII, a vida religiosa - e com ela, toda a espiritualidade cristã -, adquire uma nova dimensão, com o surgimento das ordens mendicantes, que constituem uma grande novidade na vida religiosa e na prática pastoral. Os religiosos mendicantes gozam de uma grande liberdade de movimento, podendo chegar a muito mais pessoas que os monges fechados em seus mosteiros. Dessa maneira, o interesse pela direção espiritual vai se estendendo aos fiéis leigos, que começam a receber muito mais orientação que antes. A cura animarum $^{10}$ dasordens mendicantes consistia essencialmente na formação dos fiéis mediante o officium praedicationis et confessionis, que em definitiva perseguiam o mesmo objetivo, ou seja, a formação cristã e a direção das almas dos fiéis em direção à santidade.

Nessa época, além das iniciativas das ordens mendicantes, aparecia tambémo esforço dos concílios gerais e provinciais para estimular a cura animarum. Em 1215 o Concílio Lateranense IV insistia para que nas Igrejas, catedrais e paróquias houvesse sacerdotes capazes não só de atender às confissões, mas também estivessem preparados para "as demais coisas relativas à saúde das almas" (Canon10), insistindo que o confessor não deveria ser apenas um distribuidor de absolvições, mas também um pastor e um diretor de almas. 
A vitalidade dessas novas ordens que estavam surgindo, e o prestígio e popularidade de muitos de seus religiosos, começaram a influenciar profundamente toda a vida espiritual da Igreja.

Duas particularidades básicas caracterizam as ordens mendicantes e as distinguem das monásticas, que compunham o núcleo da vida religiosa e da espiritualidade naquela época. Em primeiro lugar, o desprendimento e a pobreza; seguida de uma intensa dedicação apostólica, centrada fora dos conventos ${ }^{11}$, atividade que acontecia, no passado, muito raramente.

Uma figura importante que se destaca neste cenário, é São Francisco de Assis (1182-1226), um dos santos mais populares da história da Igreja, tendo sua vida sido muito divulgada ${ }^{12}$. Seu legado de ensinamentos e modelo de vida vem servindo de exemplo e orientação para muitas pessoas, dentro e fora dos conventos. Seus escritos foram poucos e breves, no entanto, de grande valorapostólico, especialmente as sucessivas versões da Regra. São Francisco deixou escritos que, apesar de curtos e sucintos, são uma fonte de grande importância parao conhecimento de suas ideias e inspirações. Todavia, não foi ele quem escreveu a sua própria história, por ser sempre muito avesso ao revelar a sua vida particular.Tal tarefa foi desempenhada por tantos biógrafos ao longo da rica história da ordem franciscana.

Sua pregação se caracterizava por ser direta e simples. Segundo Royo-Marín(1990), ele costumava utilizar imagens ilustrativas em pequenas parábolas ou histórias tiradas de suas experiências do cotidiano entre o povo. Apresentava a doutrina cristã de forma acessível e agradável, o que fazia com que seu discurso tivesse um profundo efeito persuasivo. Também costumava fazer uso do humor e deuma atuação com estilo teatral, a fim de tornar a sua mensagem mais compreensível e atraente.

Juntamente com São Francisco, amparada e orientada pelo mestre, Santa Clara de Assis (11931253) fundou o ramo feminino da Ordem Franciscana. Sua obra logo se tornou conhecida fazendo com que muitas mulheres e jovens viessem se juntar a ela. Em pouco tempo, foram criados mosteiros em diversas localidades da Itália, França e Alemanha. Essas religiosas eram conhecidas como Damas Pobres ou Clarissas. Dotada de uma grande capacidade de comunicação e carisma,Santa Clara foi a principal responsável pela continuidade do ideal franciscano,principalmente após a morte de São Francisco em 1226.

\subsubsection{O período da Alta Escolástica}

Um dos primeiros frutos das recém-nascidas ordens mendicantes, e um dos mais duradouros e influentes na Igreja, foi o impressionante florescimento teológico denominado a Alta Escolástica. Grandes doutores da Igreja, especialmente São Tomás de Aquino e São Boaventura, aparecem nessa época, respondendo no conjunto de seu pensamento, às principais questões espirituais de uma maneira 
sistematizada e lógica, estabelecendo um fundamento teológico sólido e definitivo, ancorado na fé e nos princípios morais fundamentais, constituindo o que viria a sera base de uma posterior reflexão teológica sobre a vida religiosa.

Com São Tomás de Aquino (1225-1274), a teologia ascética e mística alcança o seu ponto culminante, dado o alcance excepcional que a sua obra atingiu desde a sua elaboração. Na realidade, a produção literária desse Santo, impressiona pela qualidade e quantidade de sua doutrina. A lista de suas obras comconfirmação de autenticidade, supera 130 títulos. Impressiona como esse ilustre Doutor da Igreja tenha escrito tanto e tão profundos ensinamentos em uma vida tão curta (49 anos).

Na Suma Teológica de São Tomás - sua principal obra -, encontramos os princípios fundamentais da espiritualidade cristã, distribuídos em 2.652 artigos, com a solução de mais de 10.000 questões.

A Suma está dividida em três grandes partes: A primeira, subdividida em duas: Deus em si mesmo, um em essência e trino em pessoas; e Deus como criador, conservador e governador de todas as coisas. A segunda parte, também está subdividida em duas: Deus como fim último e supremo das criaturas racionais,e Meios idôneos e adequados para conseguir este fim. Nesta parte, São Tomás esclarece sobre os atos próprios e específicos do homem: os hábitos em geral e em particular, as virtudes ou hábitos bons, os vícios ou hábitos maus, os dons do Espírito Santo, etc. Nessa segunda parte, podemos encontrar alguns ensinamentos importantes e úteis para a prática da direção espiritual. São Tomás explica que a teologia não deve tratar somente dos pecados que se devem evitar, mas também das virtudes que se deve praticar e da docilidade em seguir as inspirações do Espírito Santo. Sob este aspecto, de acordo com Garrigou-Lagrange (1999, p.1229):

A teologia ascética e mística é a aplicação dos ensinamentos da teologia dogmática e moral à direção das almas em busca de uma união cada dia mais íntima com Deus. Supõem tudo o que a doutrinasagrada ensina sobre a natureza e as propriedades das virtudes cristãs e os dons do Espírito Santo, e estuda as leis e condições de seu progresso na conquista da perfeição cristã.

A ascese, segundo o mesmo Garrigou-Lagrange (1999, p. 1230), trata sobretudo, da mortificação dos vícios ou defeitos e da prática das virtudes, já a "mística se ocupa dos mistérios da fé, da íntima união com Deus, da docilidade ao Espírito Santo, da contemplação e, também, das graças extraordinárias, como as visões e revelações que acompanham a contemplação infusa"13.

A terceira parte da Suma de São Tomás está subdividida em três tópicos: O caminho para alcançar o fim último: Cristo Redentor; os sacramentos; e os novíssimos do homem. Aqui São Tomás apresenta algumas questões com argumentos importantes e úteis, em forma de orientações, para o desenvolvimentoe aprofundamento espiritual. Nessa última parte ele dedica seis interessantes questões relativas aos chamados estados de perfeição (ST II-II, q.184-189). 
Outro grande teólogo escolástico do Séc. XIII foi São Boaventura de Bagnoregio (1217-1274). A obra escrita de São Boaventura é bastante extensa, compreendendo vários tratados com conteúdo especificamente espiritual, entre o tratado teológico e o livro de orientação espiritual. A antropologia sobrenaturalapresentada por São Boaventura, é o ponto de partida de toda sua reflexão sobre a vida espiritual. Trata-se de um autor mais místico do que São Tomás, no sentido de se preocupar mais com as experiências espirituais, próprias e alheias. Parecendo também ser mais preocupado com a direção das almas do que o ilustre colega dominicano, São Tomás.

São Boaventura foi nomeado doutor da Igreja pouco depois de São Tomás deAquino: os dois primeiros a alcançarem esse titulo sem serem Padres da Igreja. SãoTomás, desde então, ficou conhecido como doutor angélico e São Boaventura comodoutor seráfico.

\subsection{NA IDADE MODERNA}

O Séc. XVI pode ser classificado como um dos mais importantes da história da espiritualidade, considerando-se o número e a qualidade dos santos e mestres espirituais, a profundidade e alcance de suas doutrinas e influência nos costumes cristãos com tão larga repercussão; e também pela grande contribuição das novas fundações e iniciativas surgidas durante o início da reforma protestante ${ }^{14}$.

Estas novas fundações se caracterizavam por uma especial preocupação com as atividades pastoral e apostólica, dirigidas à formação do clero, às obras de caridade, à pregação, ao ensino, às missões e, sobretudo, com bastante obstinação, à reconversão dos protestantes.

Nesse período, essas iniciativas adquiriram matizes diferentes segundo o caráter pessoal, a escola, o ambiente e a nacionalidade dos diversos autores. O quedesencadeia uma organização mais ágil e flexível, como uma postura mais livre e individual. Desenvolvem-se também, nessa época, as escolas mais antigas, como ados beneditinos, dominicanos e franciscanos. $\mathrm{E}$ algumas outras, que em períodos anteriores não aparecem bem delimitadas, ressurgindo mais estruturadas e exuberantes, como é o caso dos carmelitas e dos agostinianos. Da mesma forma, surgem algumas iniciativas totalmente novas, como a Companhia de Jesus fundada por Santo Inácio de Loyola, e a escola francesa do Séc. XVII.

Contemporaneamente a essas escolas encontramos também novas figuras e iniciativas de grande influência na Itália em torno do Concílio de Trento.

O santo mais popular da Itália nessa época, segundo Royo-Marín (1990), foi São Felipe Neri (1515-1595). Aos 35 anos, sua fama como confessor, diretor espiritual, mestre e pregador cresceu com grande rapidez e sua influência e popularidade atingem as mais diversas esferas da sociedade.

A doutrina de São Felipe está reunida, especialmente, nos Dichos memorables e em suas Cartas. Este grande mestre não escreveu nenhum tratadode espiritualidade, no entanto, o estilo 
sacerdotal próprio do oratório filipino e a sua influência foi sendo amplamente difundida, ganhando força especial a partir do Séc. XIX, através de figuras importantes como São João Bosco e o Cardeal Newman.

\subsection{NO “SÉCULO DE OURO” DA ESPIRITUALIDADE NA ESPANHA}

Poucas vezes na história, a vida espiritual cristã desempenhou um papel tão destacado no cotidiano das pessoas, na arte, na cultura, até mesmo, na política ena economia. Na realidade, segundo Royo-Marín (1990), na Espanha do Séc. XVI e XVII, as fundações religiosas, as pregações e os livros espirituais eram temas frequentes, das altas cortes nas cidades às tabernas nos povoados; rara era a família que não tinha um membro sacerdote, religioso ou religiosa; era difícil encontrar um nobre ou algum trabalhador naquela época que não tivesse contribuído com seu dinheiro ou trabalho na fundação de um convento; eram muitos os artistas que se inspiravam na vida ou ensinamentos de algum santo; e rara a decisão política que não tinha repercussões ou motivações religiosas de algum tipo.

A partir dessa época, este estilo de vida profundamente cristão, se estende rapidamente por toda a América Latina e grande parte da Europa, com o reforço e impulso das iniciativas em andamento na Itália.

Diante de todo esse conjunto de santos, escritos, reformas e novas fundações, destacamos em especial, quatro figuras importantes: Santo Inácio de Loyola, São João de Ávila, Santa Teresa de Jesus e São João da Cruz, que por suasantidade e prestígio - como guias/diretores e diretoras espirituais -, influenciaram de maneira decisiva tanto a vida religiosa prática das pessoas, quanto a reflexão teológico-espiritual-cristã, a partir do Séc. XVI. 


\subsubsection{Influência da Companhia de Jesus na direção espiritual}

No século XVI aparece na Espanha uma nova escola de espiritualidade cristã: a Companhia de Jesus, fundada por Santo Inácio de Loyola (1491-1556). A Ordem dos jesuítas é reconhecida principalmente por seu trabalho missionário e educacional, exercendo grande influência nos períodos iniciais da Idade Moderna.

Com os jesuítas, se inicia um novo tipo de vida religiosa que servirá de modelo às demais instituições e influenciará diretamente na reorganização e na legislação da Igreja. À meditação se incrementa uma prática organizada para o exame de consciência e direção espiritual. Assim a piedade se torna mais profunda, com um caráter mais individual. Adota-se um tipo de ascese que convém tanto à religiosos quanto à leigos através de um conjunto de exercícios praticados tendo em vista o aperfeiçoamento espiritual propostos por Santo Inácio, e difundidas até hoje pelos jesuítas, mediante seus ensinamentos e a prática da direção espiritual. O livro com os Exercícios espirituais de Santo Inácio de Loyola, é considerado um dos maisinfluentes da história da espiritualidade, uma obra, seguida de uma prática cristãque deu e continua dando inúmeros frutos de conversão e de santidade na Igreja.

A princípio, se trata de alguns procedimentos individuais para a meditação e para ajudar na reflexão e discernimento da própria vocação, que se fazia individualmente - com o diretor e o exercitado -, em uma intensa e profunda atividade de direção espiritual. Em pouco tempo, essa iniciativa de Santo Inácio mostrava a sua eficácia e percebeu-se a conveniência de uma repetição anual, que foi se estendendo entre os religiosos, sacerdotes e todo tipo de pessoas. Esses exercícios espirituais representam, sem dúvida, o legado mais importante de Santo Inácio. Refletem o genuíno espírito dos jesuítas, com um profundo sentido eclesial euma indiscutível tendência apostólica.

\subsubsection{A contribuição de São João de Ávila (1499-1569)}

Outra figura importante como grande diretor espiritual, destacado entre os principais autores do clero secular, mas que não está enquadrado propriamente em nenhuma escola de espiritualidade, é São João de Ávila. O apóstolo de Andalucía e mestre dos espirituais espanhóis do Séc. XVI, foi declarado patrono principal do clero secular espanhol em 1946. Ele tinha como objetivos de trabalho, segundo Royo-Marín (1990, p. 412-413), "Instruir os ignorantes, converter os pecadores, exortar a prática da perfeição, preservar as almas do erro e santificar o clero".

São João de Ávila foi acima de tudo um pregador e profícuo escritor ascético. Ele escreveu em 1578, o Epistolário espiritual para todos os estados, uma diversidade de cartas ascéticas dirigidas a toda classe de pessoas, desde os mais altos dignitários da Igreja até os mais humildes fiéis. 
Entre as suas obras mais divulgadas está o célebre comentário ao Salmo XLIV: Audi filia, et vide, para uma de suas convertidas em Écija, Sancha Carrillo,que foi publicado furtivamente em Alcalá em 1556 e, com maior divulgação autorizada, em Madrid em 1557. Segundo Royo-Marín (1990), pode-se considerar essa obra um verdadeiro compêndio de ascética, que tem como finalidade principal, conduzir as almas através das dificuldades inerentes à natureza humana, até os mais elevados cumes da perfeição cristã.

Com sua doutrina, São João criou uma escola sacerdotal espanhola, quemais tarde influenciaria a famosa escola sacerdotal francesa do Séc. XVII. Sua autoridade era considerada por grande parte dos santos e santas do Séc. XVI, queo reconheciam como dotado de um talento especial como diretor espiritual e com um elevado grau de discernimento. Segundo São Pedro de Alcântara, ninguém o superava no conhecimento dos caminhos do espírito (ROYO-MARÍN, 1990). E também, Santa Teresa de Jesus, o considerava com grande prestígio e um reconhecimento especial ${ }^{15}$.

\subsubsection{A decisiva contribuição feminina de Santa Teresa de Jesus (1515-1582)}

Santa Teresa possuía muitos dons, mas como escritora, tinha um talento especial e raro para analisar e descrever os acontecimentos sobrenaturais com muita simplicidade e uma impressionante clareza. Ela mesma considera isto como um dom especial de Deus: "Eu via que aquilo que os outros procuram adquirir com muito esforço, o Senhor instava comigo para que eu o recebesse, visto que, $\operatorname{nos}^{15}$ É sabido que Santa Teresa colocou muito empenho para que São João de Ávila examinasse edesse sua opinião sobre o manuscrito escrito por ela do Livro da Vida (ROYO-MARÍN, 1990, p.413). últimos anos, já me concedia gostos e regalos"16 (Livro da Vida, 9, n. 9. In.:ALVAREZ, 1995).

Na realidade, Santa Teresa foi, e continua sendo, uma figura importante na história da espiritualidade cristã. Ela tinha uma personalidade alegre e extrovertida que atraia a todos, com seu estilo característico, sua profundidade, seus talentos e habilidades de se comunicar, se tornou a primeira mulher Doutora da Igreja e a santa espanhola mais popular. Definitivamente, de acordo com Sesé (2005), seus escritos são uma fonte inesgotável e riquíssima da mística cristã.

Uma das particularidades mais características da mística teresiana é o seu caráter marcadamente psicológico, desprovido de teorias filosóficas. Santa Teresa relata o que experimenta, e descreve o que lhe passa na alma não se preocupando em explicar filosoficamente em que consiste a união mística. Seus escritos não têm nenhuma pretensão filosófica, sistemática ou metódica, entretanto, têm claros os seus objetivos. Ela sabia como organizá-los e relatá-los, conseguindo alcançar, ao tratar de questões complexas, uma profundidade e uma clareza dificilmente encontradas em outros autores. 
Santa Teresa tinha uma especial consideração e dava grande importância à direção espiritual. De acordo com Frei Alvarez (1995), ela contava sempre com o acompanhamento de um diretor e, ao mesmo tempo, tratava também de dirigir e conduzir espiritualmente as suas irmãs religiosas. $\mathrm{Na}$ realidade, uma grande partede suas obras respondem à essa sua intenção particular de direção espiritual das almas. Em vários de seus escritos, ela costuma recomendar com insistência que com o acompanhamento de um bom diretor espiritual se avança com mais segurança e rapidez na união com Deus.

Caminho de Perfeição é um livro de formação espiritual escrito por Santa Teresa para suas monjas no convento. Segundo Frei Alvarez, (1995, p. 295), foi composto pela filial insistência de suas destinatárias. Privadas da leitura do primeiro livro da Madre, o Livro da Vida - que circulava de mão em mão somente entre os confessores -, solicitaram também para elas algumas páginas espirituais, com orientações e conselhos práticos para a iniciação na vida de oração e o encaminhamento em direção a uma vida de santidade. A insistência foi tanta que, segundo Frei Alvarez (1995, p. 295), Santa Teresa se rendeu aos pedidos das monjas, e desabafou no prólogo primitivo daquele livro: "Era tamanho o desejo em que as vi, e a importunação, que me determinei a fazê-lo".

Neste mesmo livro podemos encontrar um exemplo da direção espiritual de Santa Teresa destinada às suas monjas: "A quem deseja alcançar a contemplação, precisa, para ir com segurança, sujeitar sua vontade, com toda a determinação, aum confessor experiente. Porque é sabido que se aproveita mais com isso em um ano, do que em muitos sem isso" (Caminho de Perfeição 18, 8. In.: ALVAREZ, 1995).

Esta santa de Ávila foi canonizada em 12 de Março de 1622, quarenta anos após à sua morte, e proclamada Doutora da Igreja em 27 de Setembro de 1970,pelo Papa Paulo VI, que na ocasião se referiu a ela como "escritora genialíssima e fecunda, mestra de vida espiritual, contemplativa incomparável e incansavelmente ativa" ${ }^{17}$.

\subsubsection{O aporte de São João da Cruz (1542-1591)}

São João da $\mathrm{Cruz}^{18}$, frade carmelita espanhol, famoso por suas poesias místicas e admirável mestre espiritual, de acordo com Stinissen, costumava lembrar que muitas almas não conseguem alcançar à perfeição, porque não encontram quem as orientem adequadamente:

Deste modo, alguns diretores espirituais prejudicam grandemente muitas almas; como não entendem as vias e peculiaridade do espírito, ordinariamente, induzem as almas à perda das unções e inspirações com que o Espírito Santo vai ungindo e as dispondo para si (STINISSEN, 2010, p. 44). 
Segundo Garrido (2010), São João da Cruz, assim como Santa Teresa, frequentemente recomendava a todos que buscassem um diretor espiritual quefosse uma pessoa sábia, discreta e experiente no trato com Deus. Por isso, a alma que pretende avançar em direção à perfeição, segundo o conselho desse santo mestre: "Deve considerar bem em que mãos se coloca porque tal seja o mestre, tal será o discípulo; e tal seja o pai, tal será o filho". Garrido continua a explicação citando novamente as palavras de São João: "Não só o diretor deve ser sábio e prudente, como também experimentado. Se o guia espiritual não tem experiência de vida espiritual, é incapaz de conduzir as almas que Deus chama, e inclusive não as compreenderá" (Chama 3, n. 30. In.: GARRIDO, 2010). Em várias de suas obras, São João adverte sobre a importância e necessidade da direção espiritual. Especialmente, em Ditos de Luz e Amor, ele se dirigia às suas irmãs carmelitas:

Quem quiser estar sem assistência e sem guia, será como uma árvore que está só e sem dono no campo, que por mais frutos que dê, os viandante os colherão e eles não chegaram a amadurecer. A árvore cultivada e conservada com os bons cuidados do dono, dará os frutos no tempo certo. A alma só, sem mestre que tenha virtude, écomo o carvão acesso que está só; antes se irá apagando ao invés de acendendo (Ditos de Luz e Amor, n. 5, 6 e 7. In.: GARRIDO, 2010).

A história da espiritualidade cristã foi certamente bastante influenciada pelos ensinamentos de Santa Teresa e São João da Cruz. Não só por terem realizados juntos a grande reforma carmelita, mas também porque as suas doutrinas se explicam e se complementam mutuamente de uma maneira admirável. Santa Teresa se encarregando em descrever os fenômenos místicos sobrenaturais que experimenta, desde sua perspectiva feminina, e São João os aprofundando filosoficamente. Essa complementaridade acontece em suas vidas já desde o primeiro e decisivo encontro, como explica Sesé (2005), e se reflete em ambos magistérios, multiplicando notavelmente sua eficácia, tanto no campo da mística experiencial, como no estudo teológico.

\subsubsection{Algumas santas mulheres na europa}

A fim de completar-se o pensamento e as contribuições com relação ao tema da direção espiritual ao longo dos séculos, parece pertinente mencionar-se o nome de algumas mulheres na Europa, que por sua obra, modelo de vida e santidade, deixaram uma marca significativa, exercendo a sua maternidade espiritual.

\subsubsection{As beneditinas na Alemanha}

A primeira de uma série de mulheres influentes tanto na religião como na política, e uma representante típica da aristocracia cultural beneditina, foi a Beata Hildegarda de Bingen (1098-1179). Rompendo todas as barreiras e preconceitos contra as mulheres que existiam na época, era respeitada 
como uma grandeautoridade em assuntos teológicos por seus contemporâneos. E ainda hoje, é considerada uma figura singular na história da espiritualidade do século XII europeu. A Beata Hidelgarda ${ }^{19}$ era médica - curava corpos -, e ao mesmo tempo, através de sua direção espiritual, curava também muitas almas. Seus vários escritosmostram que ela possuía uma concepção mística e integrada do universo, aindaque essa concepção não excluísse o realismo e encontrasse no mundo muitosproblemas. A solução para eles, de acordo com suas ideias, devia advir de uma união cooperativa e harmoniosa entre corpo e espírito, entre natureza, vontade humana e graça divina.

Sua obra mais importante Sci vias Domini (Conhece os caminhos do Senhor),foi escrito entre os anos 1141 e 1151. Com as mesmas características de apostolado, encontramos As obras do Senhor e A vida meritória. Encontram-sealém disso, umas 300 cartas compondo uma literatura mística marcadamente descritiva e experimental, incluindo revelações privadas e outras graças extraordinárias. A obra de Santa Hidelgarda trás uma rica doutrina sobre a purificação da alma, a contemplação, a importância das virtudes e especialmente a docilidade às inspirações do Espírito Santo, ensinamentos que constituem os princípios e o fundamento da direção espiritual.

Na Alemanha, aparecem destacadas também as beneditinas: Santa Matilde de Magdeburgo (1212-1283), Santa Matilde de Hackeborn (1241-1299) e Santa Gertrudis a Grande (1256-1301), que por seu prestígio e influência de suas obras, fizeram grande número de discípulos, deixando valiosas lições para o encaminhamento das almas e a prática da direção espiritual.

\subsubsection{Santa Catarina de Sena (1347-1380)}

Entre todos os santos, escritores e fundadores já mencionados, Santa Catarina de Siena, foi uma das mais preocupadas e ocupadas - de uma maneira objetiva e prática -, em orientar e conduzir a seus irmãos cristãos pelos caminhos que levam a Deus. Entre seus ensinamentos, Santa Catarina costumava pregar com determinação, a prática das virtudes e a necessidade do acompanhamento de umdiretor espiritual que fosse digno e confiável:

Uma coisa vos peço: não andeis a procura de muitos conselheiros. Escolhei um, que vos oriente santamente, e obedecei-lhe [...] Portanto, o melhor e mais necessário é que a pessoa escolha um conselheiro e procure ser perfeita naquilo que ele disser" (SENA, 2005, p. 279).

Entre suas obras escritas (ou melhor, ditadas, pois era analfabeta), se destaca o Diálogo sobre a Divina Providência, um livro ainda hoje considerado um dos maiores testemunhos do misticismo cristão, com uma exposição clara das ideias teológicas e a espiritualidade desta importante mística dominicana italiana.Em 1970, o Papa Paulo VI proclamou-a Doutora da Igreja, sendo a primeira leiga 
a obter esta distinção. O Papa João Paulo II a declarou copadroeira da Europa, juntamente com Santa Brígida da Suécia e Santa Teresa Benedita da Cruz (Edith Stein).

\subsubsection{Santa Teresa do Menino Jesus (1873-1897)}

Poucas pessoas na história da espiritualidade cristã, contribuíram tão intensamente e com tanta profundidade quanto Santa Teresinha, apesar de ter vivido uma vida tão curta. Em 1888, com apenas quatorze anos, insistiu determinadamente com o Bispo para conseguir a dispensa e entrar para o Carmelo. Neste mesmo ano, ela começou a escrever o relato de sua vida. Em 1896, Santa Teresinha começa a padecer uma dolorosa enfermidade. Apesar disso, continua a escrever, obedecendo à solicitação da Madre superiora. Alguns meses depois, essa jovem santa de apenas 24 anos, morre serenamente na enfermaria do mesmo convento em Lisieux.

Como ela mesma já havia intuído, a verdadeira história de Teresinha estava apenas começando. No ano seguinte aparece a primeira edição da História de uma alma, que foi difundida com grande rapidez, seguida de várias reedições e traduzidas em diversos idiomas. Seus processos de beatificação e canonização bateram todos os recordes de velocidade da época, e as cerimônias correspondentes, recordes de assistência. A influência de seus escritos se estendeuem todos os níveis, desde as pessoas mais simples até os mais eruditos teólogos. Esua nomeação como Doutora da Igreja veio a confirmar a importância de sua doutrina. Junto aos três Manuscritos autobiográficos que deram lugar ao livro História de uma alma, Santa Teresinha deixa muitos ensinamentos distribuídos em suas 266 cartas, 54 poesias, 21 orações e suas Últimas Conversas (frases recolhidas por algumas monjas, em seus últimos meses de vida), e também, em suas Obras de teatro (8), que compôs para as festas do Carmelo.

De acordo com os manuscritos autobiográficos da História de uma alma, Santa Teresinha (JESUS, 2008, p. 258), de 1893 a 1896, se encarregava de olhar pelas suas companheiras de noviciado, como "decana" ou como "anjo", termo que designava a religiosa encarregada de ajudar uma postulante em sua adaptação à vida conventual. A partir de março de 1896, ela tornou-se mestra das noviças.

Com relação à direção espiritual ela falava frequentemente: "O Bom Deus dignou-se encherme a mãozinha tantas vezes quantas eram necessárias para nutrir a alma de minhas irmãs” (JESUS, 2008, p. 258); e continuava, explicando o que é necessário a um bom guia espiritual: "Saber discriminar o que o Bom Deus exige das almas, e coadjuvar a ação de sua graça, sem que a ultrapasse ou retarde" (JESUS, 2008, p.130). "Da mesma forma que os filhotes de passarinhos aprendema cantar, ouvindo a seus pais, assim também as crianças aprendem a ciência das virtudes, o sublime canto do Amor Divino, no trato com as almas encarregadas de formá-las para a vida”(JESUS, 2008, p. 131). 
Grande parte do êxito e influência de Santa Teresinha, segundo Royo-Marín (1990), vêm da sua forma simples de escrever e se expressar, encadeando harmonicamente o que ensinava com o que vivia.

\subsection{A DIREÇÃO ESPIRITUAL DIANTE DOS DESAFIOS DO MUNDO MODERNO}

Os anos seguintes ao Concílio Vaticano II, de acordo com Sesé (2005), foi um período de contrastes na história da espiritualidade cristã. Com alguns avanços positivos em bastantes aspectos e fortes crises em outros, junto aos novos e decisivos desafios que aparecem com a rápida evolução da sociedade no final do Séc. XX. O liberalismo, o crescente laicismo na sociedade, as diversas formas de ateísmo, o socialismo e o marxismo surgem criando sérios problemas para o progresso espiritual do Cristianismo, levando a uma progressiva descristianização em diversos âmbitos da sociedade. Contudo, a partir da visão Conciliar, a Igreja sente-se convocada a estabelecer um diálogo profundo com o mundo contemporâneo e assume uma atitude positiva frente aos desafios lançados e tenta encontrar os pontos positivos de todo o progresso vivido pela sociedade.

O magistério eclesiástico, tratou muitas vezes, aprovando e animando aprática da direção espiritual e, com o mesmo cuidado, condenando algumas doutrinas contrárias ou não favoráveis à essa prática (Testem benevolentiae, 22 de janeiro de 1899). E a partir da doutrina do Concílio Vaticano II (OT 8, PO 18, PC 18, GE 10), a direção espiritual tem sido objeto de sérias considerações, principalmente nas disposições para a ação pastoral e na forma de falar do acompanhamento espiritual das vocações. Para os seminários e os institutos religiosos, os documentos oficiais determinam sempre a direção espiritual como prática que deve ser difundida e estimulada. E no Decreto Presbyterorum ordinis (18), recomenda-se especificamente aos sacerdotes que "estimulem muito a direção espiritual".

A contribuição do Concílio Vaticano II, nesse sentido, foi extremamente importante, sobretudo, pela solene proclamação da chamada universal à santidade. No capítulo V da Constituição Dogmática Lumen gentium, encontra-se clara a universalidade da chamada divina e a vocação de todos, sem exceção, para a santidade na Igreja:

Todos na Igreja, quer pertençam à hierarquia quer por ela sejam pastoreados, são chamados à santidade, segundo a palavra do Apóstolo: "esta é a vontade de Deus, a vossa santificação" (1 Tess. 4,3; Ef. 1,4). Esta santidade da Igreja incessantemente se manifesta,e deve manifestar-se, nos frutos da graça que o Espírito Santoproduz nos fiéis; exprime-se de muitas maneiras em cada um daqueles que, no seu estado de vida, tendem à perfeição da caridade, com edificação do próximo; aparece dum modo especial na prática dos conselhos chamados evangélicos. A prática destes conselhos, abraçada sob a moção do Espírito Santo por muitoscristãos, quer privadamente quer nas condições ou estados aprovados pela Igreja, leva e deve levar ao mundo um admirável 
testemunho e exemplo desta santidade [...] Todos os fiéis se santificarão cada dia mais nas condições, tarefas e circunstâncias daprópria vida e através de todas elas, se receberem tudo com fé da mão do Pai celeste e cooperarem com a divina vontade, manifestando a todos, na própria atividade temporal, a caridade com que Deus amou o mundo (LG, 39-41).

Evidentemente, a maior novidade desse Concílio está no que se refere à vida dos fiéis leigos: consolidando as contribuições práticas e doutrinais dos mestres antigos e abrindo definitivamente um caminho para todos os cristãos no sentido de viverem a santidade no meio do mundo.

Propomos, a seguir, duas personalidades que, no âmbito da espiritualidade cristã, dão uma contribuição significativa à forma como a Igreja busca exercer sua maternidade e paternidade espiritual com relação aos seus filhos e filhas diante dos desafios do mundo contemporâneo. São experiências suscitadas pelo Espírito Santo em resposta a sede de sentido vivido pelo ser humano diante dos desastres daqueles anos de terror, medo e guerra na Europa dos finais do século XX. Neste contexto e, segundo as exigências do Evangelho, Josemaría Escrivá e Chiara Lubic apresentam-se com o desejo de oferecer ao homem e mulher feridos e destruídos, a possibilidade da vivência e acompanhamento na vida de encontro com Cristo no Espírito.

\subsubsection{São Josemaría Escrivá e o Opus Dei}

$\mathrm{O}$ chamado universal à santidade ${ }^{20} \mathrm{e}$ o caminho para a santificação notrabalho do dia-a-dia $\mathrm{e}$ no cumprimento dos deveres cotidianos dos cristãos, são os pontos focais de todo o ensinamento espiritual de São Josemaría Escrivá. Como afirma a seguir, a preocupação de Escrivá, será a de promover o desenvolvimento de pessoas que se sintam protagonistas na história:

O exercício da direção espiritual não deve orientar-se no sentido de fabricar criaturas carentes de juízo próprio, que se limitem a executarmaterialmente o que outrem lhes disse; pelo contrario, a direção espiritual deve tender a formar pessoas de critério. E o critério implica maturidade, firmeza de convicções, conhecimento suficiente da doutrina, delicadeza de espírito e educação da vontade (ESCRIVÁ, 1986, n. 93).

Na realidade, Deus chama todos os homens à santidade, sem distinção de estado, condição, idade, sexo, raça, cultura ou qualquer outra situação. É um convite que existe desde os primórdios do Cristianismo, onde a Igreja propõe a todo cristão, como uma manifestação do amor de Deus a cada um de seus filhos, único eirrepetível, e que se realiza através das circunstâncias individuais e específicas de cada um. Esta é uma perspectiva nova que abre a possibilidade também aos leigos de viverem uma vida santa. Todos, leigos ou religiosos, são chamados, segundo os ensinamentos de São Josemaría, não apesar do mundo, mas através do mundo e das circunstâncias da sua vida: no trabalho, na família, nas relações sociais, etc.Não vos digo: abandonai a cidade e afastai-vos dos negócios. Não. 
Permanecei onde estais, e praticai as virtudes ${ }^{21}$. Isso dizia um santo do Séc. IV e repetia o fundador do Opus $D e i^{22}$, ao anunciar o que Deus espera de cada um na sua vida cotidiana e no trabalho feito com amor.

No ponto n. 34 de seu livro, É Cristo que passa, este grande mestre espiritual lembra aos fiéis que "Cristo deu à sua Igreja a segurança da doutrina, a corrente de graça dos sacramentos; e cuidou para que houvesse pessoas que pudessem orientar, para nos conduzir e para lembrar constantemente o nosso caminho" (ESCRIVÁ, 1975). Com relação à direção espiritual, São Josemaría sempre foi enfático ao recomendar:

Convém que conheças esta doutrina segura: o espírito próprioé mau conselheiro, mau piloto para dirigir as almas nas borrascas e tempestades, por entre os escolhos da vida interior. Por isso, é Vontade de Deus que a direção da nau esteja entregue a um mestre, para que, com a luz e o conhecimento, nos conduza ao porto seguro (ESCRIVÁ, 1999,n. 59).

São Josemaría costumava falar da antiga novidade da mensagem que recebeu de Deus: antiga como o Evangelho e, como o Evangelho, nova. Antiga, porque o espírito do Opus $D e i^{23}$ é aquele que viveram os primeiros cristãos, que tinham consciência de ser chamados à santidade e ao apostolado sem saírem do mundo, nas suas ocupações e tarefas diárias. Por isso, "uma maneira simples para entender-se o espírito do Opus Dei é pensar na vida dos primeiros cristãos: viviam profundamente a sua vocação cristã, procurando seriamente a perfeição a que estavam chamados pelo fato, simples e sublime, do Batismo" (ESCRIVÁ, 1986, n. 24).

O mesmo São Josemaría, costumava dizer, segundo Bernal (1980), que Deus pode escrever ainda que seja com "la pata de una mesa" (a perna de uma mesa); com a condição, obviamente, de que esse instrumento tosco e desproporcionado que somos, deixe-se usar, servindo no misterioso entrecruzar-se da liberdade e da graça.

Este santo moderno costumava ter como o centro de suas pregações a ideia de que qualquer trabalho honesto pode ser santificado. "Tornar-te santo, converter- te em obra de Deus. E o trabalho assim santificado, nos identifica com Cristo - perfeito Deus e perfeito Homem -, nos santifica e aperfeiçoa, transformando-nos na sua imagem"24. Para São Josemaría "ser santo supõe santificar o próprio trabalho, santificar-se em seu trabalho, santificar os outros com o trabalho"25, e assim, encontrar a Deus.

Durante o período imediato do pós-guerra na Espanha, se intensificaram muito as incompreensões por parte daqueles que não entendiam o "chamamento universal à santidade", incessantemente pregado por São Josemaría. Por essa razão, o Opus Dei e o seu fundador foram várias vezes vítimas de calúnias por partedessas pessoas que não aceitavam o espírito da organização, 
considerado como extremamente radical e progressista para aquele tempo. Entretanto, apesar das perseguições e dificuldades de toda ordem, a Obra continua se desenvolvendo e sendo difundida com muita rapidez. A partir de 14 de fevereiro de 1930, o apostolado foi estendido também às mulheres. Em 1933 é aberto o primeiro centro do Opus Dei, a Academia DYA, destinada principalmente a estudantes de Direito e Arquitetura. A Academia transforma-se numa residência universitária onde São Josemaría e os primeiros membros vão difundir a mensagem do Opus Dei entre os jovens; simultaneamente realizam catequese e atendimento aos pobres e doentes dos bairros periféricos de Madrid.

Profundamente influenciado pelos ensinamentos de Santa Teresa de Jesus ${ }^{26}$,em 1934 São Josemaría publica com o título provisório de Considerações espirituais, a primeira edição de Caminho, a sua obra mais difundida, da qual já foram editados mais de quatro milhões de exemplares. Vê-se, portanto, a partirdeste dado, que o estudo da história da espiritualidade e da direção espiritual nos permite perseguir o desenvolvimento das ideias e a forma como elas podem ser traduzidas, em cada época, a fim de servir a sede e a busca do ser humano.

Durante toda a década de 50, esse santo incansável, organizou e incentivouo início de vários projetos sociais: escolas de formação profissional, centros de capacitação para camponeses, universidades, colégios, hospitais e ambulatórios médicos, etc. Estas atividades eram frutos da iniciativa de fiéis cristãos comuns que desejavam atender - com mentalidade laical e com sentido profissional - as necessidades concretas de um determinado lugar. Essas atividades continuam funcionando, abertas às pessoas de todas as raças, religiões e condições sociais. E a Obra, que teve início na Espanha, hoje se encontra espalhada por todos os cinco continentes.

\subsubsection{Chiara Lubich e a perspectiva feminina moderna}

Assim como São Josemaría Escrivá, a italiana Chiara Lubich (1920-2008), a partir da sua concepção feminina, desempenhou um papel importante como mestre e guia espiritual, com uma consciência indelével da sua missão pessoal.

A caminhada de Chiara começou no início da década de 40, com pouco mais de vinte anos de idade, ela começa o seu trabalho lecionando como professora em escolas primárias de sua cidade natal, Trento. Enquanto trabalhava, ingressou na Universidade de Veneza onde dá início aos seus estudos em filosofia. Procurando a verdade profunda das coisas, no clima inóspito da II Guerra Mundial, descobre que Deus era para ela o único, eterno e absoluto ideal. Divide então esta descobertacom outras companheiras e juntas formam um pequeno grupo, constituindo assim o primeiro núcleo do futuro movimento dos Focolares ${ }^{27}$. Em 7 de Dezembro de 1943, sozinha na capela, faz uma promessa a Deus de doar somente a Ele, e para sempre, toda a sua vida. Esta data é considerada o marco inicial desse 
Movimento. Em 13 de Maio de 1944, a casa onde morava foi totalmente destruída por um violento bombardeio que atingiu Trento. Todos seus familiares foram refugiar-se nasmontanhas. Foi quando Chiara decidiu permanecer sozinha na cidade, com o firme propósito de sustentar seus ideais e a sua vocação.

Alguns anos depois, no parlamento italiano, Chiara conheceu o político Igino Giordani, que foi co-fundador do Movimento. Igino era deputado, escritor, jornalistae pai de quatro filhos. Em 1949, Chiara encontrou Pasquale Foresi, um jovem seminarista que sentia a forte exigência de conjugar o Evangelho e a vida na Igreja. Ordenado sacerdote em 1954, Dom Foresi foi o primeiro focolarino Sacerdote. Em 1956 reúne o grupo denominado Os Voluntários de Deus, com pessoas de diversas áreas, empenhadas e comprometidas em levar Deus à sociedade. Em 1964, Chiara fundou a "cidadezinha" de Loppiano nas colinas de Valdarno, próximo a Florença. A primeira de uma série de outras cidades em vários países do mundo que trabalham em prol de um Mundo Unido, onde procuram viver a espiritualidade da unidade, 24 horas por dia em, absolutamente, todos os aspectos da vida. Em 1966, propôs aos jovens a radicalidade do Evangelho dando vida ao Movimento Gen (Geração Nova). Em 1977, recebe em Londres o prêmio Templeton para o desenvolvimento das religiões. De 1997 a 1998 se dedicou intensamente a abrir novas perspectivas de diálogo inter-religioso: foi convidada a falar da experiência interior na Tailândia a 800 monges budistas; em Nova York a 3.000 muçulmanos negros na mesquita de Harlem, e na Argentina à comunidade Hebraica de Buenos Aires. Em setembro de 1998, em Estrasburgo, recebe do Conselho Europeu, o Prêmio Direitos Humanos. Recebeu também outros diversos prêmios e laures Honoris Causa, cidadanias honorárias, na Itália e em todo o mundo.

Em uma atmosfera serena, de oração e de profunda comoção, Chiara Lubich falece na noite de 14 março de 2008, aos 88 anos.

Chiara, de acordo com Franca Zambonini (2010, p. 79), era uma pessoa muito carismática e estimada por todos que a conheciam. Depois de sua morte, foram muitos os depoimentos de carinho e admiração dirigidos a ela: "Mulher de fé intrépida, mansa mensageira de esperança e de paz”, escreveu Bento XVI numa carta enviada através do cardeal Bertone e lida durante a celebração fúnebre no dia seguinte à sua morte. Salvatori Martinez, coordenador italiano da Renovação Carismática se dirigiu a ela, prestando sua homenagem, afirmando que "A herança de Chiara é uma herança de amor marcada por uma maternidade espiritual pelaqual todos nós, leigos, lhe somos extremamente gratos". Também, o presidente da República Italiana, Giorgio Napoletano, na época, definiu Chiara Lubich como "uma das personalidades mais representativas do diálogo inter-religioso e intercultural, uma voz rigorosa e límpida no debate contemporâneo. Mulher forte que soube fundar um dos Movimentos mais difundidos do mundo, capaz de deparar-se, com espírito aberto, com o mundo leigo, tendo por base a supremacia dos ideais humanos da solidariedade, da justiça, da paz entre povos e nações". 


\section{PSICOLOGIA E VIDA ESPIRITUAL}

Em seguida à explanação sobre o perfil histórico do acompanhamento espiritual ao longo dos séculos, prosseguimos focalizando alguns aspectos da psicologia com relação à direção espiritual. Destacando a sua natureza e a sua diferenciação do atendimento em psicoterapia clinica.

\subsection{A INTERAÇÃO ENTRE RAZÃO, EMOÇÃO E A VONTADE}

A interação entre razão e emoção é atualmente um dos campos mais fascinantes no estudo sobre o comportamento humano. Segundo o psicólogo norte americano Paul Ekman, os sentimentos não são mais inatingíveis nem ilusórios, como se pensava no passado (EKMAN, 2006).

Em 1872, Charles Darwin, demonstrava como as emoções estão ligadas a mecanismos evolutivos essenciais à preservação da espécie. As reações fisiológicas desencadeadas pela raiva, alegria, tristeza, sentimento de culpa, vingança, etc., teriam, segundo ele, um valor adaptativo relevante.

Durante a década de 60, ao se aprofundar nos estudos de Darwin sobre as emoções, Ekman (2006) comparou em duas dezenas de países, a expressão facial das pessoas durante a manifestação dos diversos sentimentos, dedicando-se sobretudo a seis em especial, considerados básicos. O medo, a surpresa, a raiva, a alegria, a tristeza e o nojo são, de acordo com esse pesquisador, manifestações inatas, ou seja, determinados biologicamente - e comuns, também, entrevertebrados mais simples. Nos peixes, anfíbios e répteis, as emoções se manifestam de forma involuntária, ativando as áreas mais primitivas do cérebro, como o tronco vertebral e o sistema límbico. Conforme aumenta o grau de evolução da espécie, as emoções tornam-se mais refinadas e complexas - o que exige a ativação de porções cerebrais maiores e mais desenvolvidas.

No ser humano, as percepções e manifestações emocionais atingem o auge da complexidade e são processadas em todo o cérebro, inclusive no córtex primitivoe no neocórtex, responsáveis por funções como a linguagem e a tomada de decisões. O ser humano é o único animal capaz de experimentar as chamadas emoções secundárias. Dezenas de substâncias químicas interagem entre si de modo que sintamos medo, compaixão, culpa, ciúme, vergonha, desconfiança, insegurança, amor, ódio, etc.

Além de mais complexas fisiologicamente, as emoções humanas, são também, diretamente influenciadas por estímulos sociais, culturais e, especialmente,morais. E se retroalimentam. Como explica, poeticamente, o escritor inglês Edward Morgan Forster: As emoções são intermináveis: quanto mais as exprimimos, mais maneiras temos de exprimi-las (FORSTER, 2009).

Na figura ilustrativa abaixo, percebemos a evolução das emoções desde as mais simples até as mais complexas - específicas dos seres humanos. 
Figura 1 - A evolução das emoções

A EVOLUÇÃO DAS EMOÇÕES $\begin{aligned} & \text { Dos animais vertebrados mais simples ao homem, como } \\ & \text { as emoçōes se tornaram mais complexas* }\end{aligned}$

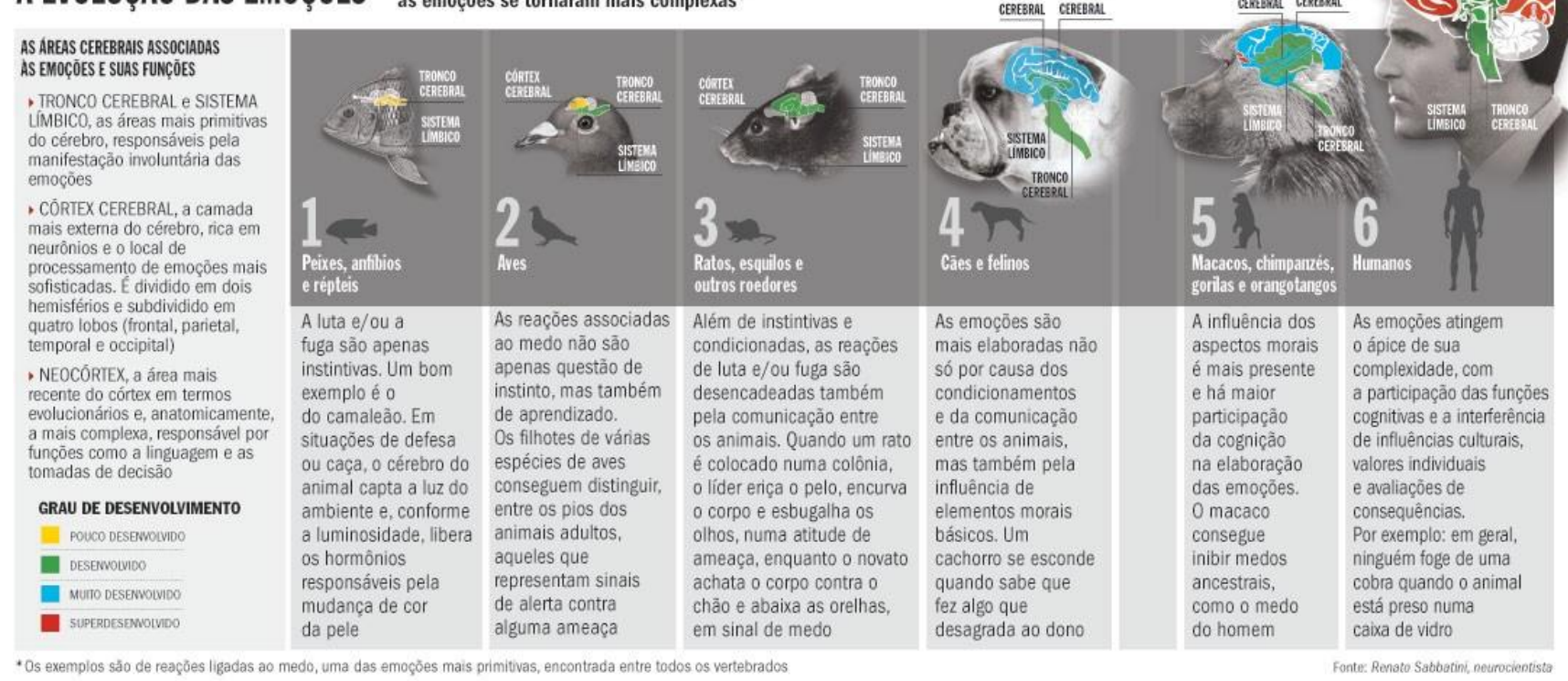

Fonte: Sabbatini (2001)

A Psicologia enquanto saber que se ocupa da exploração do ser humano em toda sua integridade ${ }^{28}$, estabelece as suas raízes nos terrenos da Filosofia e da Religião. Até o final do século XIX, eram os filósofos e os teólogos, quase que exclusivamente, os que se encarregavam de estudar a alma ou psique humana.

A reviravolta cultural que, desde do Renascimento, deu início às denominadas Ciências separadas - separadas da Teologia e da Metafísica -, desencadeou no final do século XIX - em pleno positivismo -, o propósito de se construir uma psicologia que fosse científica.

Essa nova ciência nasceu no ano de 1879, por obra de um médico alemão: Wilhelm Wundt (1832-1920), o qual era professor justamente de Filosofia, na Universidade em Leipzig.

O tentador intento de transformar a Psicologia em uma ciência natural, que medisse e calculasse os fenômenos psíquicos mediante instrumentos e aparatos mecânicos, se expandiu rapidamente graças a Stumpf e Külpe, discípulos de Wundt, que abrem novos laboratórios em Munich, Berlim e Würzburg. Criam-se as primeiras cátedras de Psicologia, sempre dentro das faculdades de Filosofia.

Pouco a pouco a Psicologia se torna prática. São desenvolvidos os testes psicotécnicos, aplicados nas mais diversas áreas, auxiliando na seleção de pessoal profissional, na estruturação empresarial, nos centros educativos, políticos, etc.Inclusive foram usados em situações trágicas como no caso do racismo nos camposde concentração nazistas, onde médicos e psicólogos trabalhavam fazendo a seleção para decidir quais as pessoas que valiam a pena ou não, se conservar a vida.

O prestigio da Psicologia empírica e da psicotécnica - com notável potencial manipulativo -, vai crescendo de maneira acentuada no século XX, especialmente nos Estados Unidos e na Europa, 
onde esse boom científico tem uma grande repercussão, sobretudo a partir do ano de 1900, com as teorias psicanalíticas de Freud e, mais tarde, as de Adler.

Com a Psicologia moderna, nascida no âmbito das ciências naturais, surge a tendência, como nas outras ciências, de dividir seu objeto, com a finalidade de conhecê-lo com maior exatidão. Aparece então na Psicologia, de modo inconsequente, a especialização. A psique (alma), passa a ser considerada isoladamente e estudada como objeto separado. O grande problema dessa perspectiva é perder-se de vista o homem integral, a pessoa real, única, indivisível eirrepetível. Para Viktor Frankl (1988), o mal não é que os especialistas se especializem, e sim, que os especialistas generalizem. Da Biologia se passa ao biologismo, da Sociologia ao sociologismo e da Psicologia ao psicologismo. Essa extralimitação das ciências empíricas, de acordo com Torelló (1987), passou a estar na ordem do dia, se tratando de um autêntico escândalo cultural deconsequências nefastas.

É preciso reconhecer que nunca o homem soube tanto de si mesmo como na atualidade e que, no fundo, nunca soube menos em tudo o que se refere à sua definição e ao sentido último de sua existência (GEBSATTEL,1966, p. 80).

Segundo Torelló (1987, p. 21), as ciências humanas são úteis, e mesmo necessárias, para se chegar a um maior conhecimento desse "ser fronteiriço" (ou limítrofe) que é o homem: "Sempre único, e constantemente movendo-se por entre as frestas que separam dois abismos: o tempo e a eternidade, o corpo e o espírito". Torelló continua, explicando que essa unidade reside no homem vivo: "vivus quia unus, unus quia vivus - vivo por ser único, único por ser vivo” (TORELLÓ, 1987, p. 22). Entretanto, tanto as ciências biológicas quanto as psicológicas não se mostramcapazes de alcançar essa dimensão transcendente do ser humano.

Não resta dúvida que a Filosofia marcou definitivamente todo processo de desenvolvimento da Psicologia ao longo da sua história. E da mesma forma aconteceu com a Medicina. Tanto a Filosofia como a Psicologia e a Medicina, como não poderia ser diferente, devem se ocupar em estudar o homem integralmente, com toda sua profundidade e em todas as suas dimensões.

O homem é um ser único, composto de um corpo e uma alma - indivisíveis, inseparáveis -, intrinsecamente unidos. De acordo com Yepes; Aranguren (1999), apessoa é um in-dividuum. E o conceito de indivíduo reclama a unidade. Portanto, à pessoa não se admite separação, subdivisão ou excisão. Segundo Gómez-Peréz (1980, p. 134), “O ser humano não é só corpo nem só alma, mas a unidade decorpo e alma. Tudo o que o homem é e faz é imputável ao homem inteiro, corpo e alma numa unidade substancial". Assim, também para Ayllón (2001), o ponto de partida e o marco de referência para a compreensão teórica e a dinâmica das teses antropológicas da existência humana, corresponde ao estudo da noção de pessoa enquanto unifica e totaliza o homem em toda sua integridade. Portanto, a Psicologiavista desse prisma, é aquela que abarca - assim como deve ser nas outras ciências 
humanas -, o estudo do homem considerado em todas as suas dimensões - biológica, psíquica e noológica.

A dinâmica vital do homem, seu desenvolvimento, plenitude e autorealização,dependem da harmonia $^{29}$ e da integridade existentes entre todos os âmbitos da natureza humana (Quadro 1 Dinâmica do desenvolvimento humano).

Quadro 1 - Dinâmica do desenvovimento humanoElaboração da autora (sem publicação prévia)

\begin{tabular}{|c|c|c|c|c|}
\hline \multicolumn{5}{|c|}{ Dinâmica do Desenvolvimento Humano } \\
\hline $\begin{array}{c}\text { DIMENSÕES } \\
\text { Humanas }\end{array}$ & $\begin{array}{c}5 \text { ÂMBITOS de } \\
\text { Desenvolvimento }\end{array}$ & $\begin{array}{c}\text { NECESSIDADES } \\
\text { Naturais }\end{array}$ & $\begin{array}{c}\text { ESTRATÉGIAS } \\
\text { paraSATISFAÇÃO } \\
\text { das } \\
\text { Necessidades }\end{array}$ & $\begin{array}{c}\text { RESULTADO } \\
\text { natural }\end{array}$ \\
\hline $\begin{array}{c}\text { BIOLÓGICA } \\
\text { (Matéria) } \\
\square\end{array}$ & $\begin{array}{l}\text { FÍSICO } \\
\text { Corpo }\end{array}$ & $\begin{array}{c}\text { SUSTENTAÇÃO } \\
\text { CORPORAL } \\
\text { Necessidade de Subsistência } \\
\text { alimentação, medicação, } \\
\text { confortofísico; procriação, etc. }\end{array}$ & $\begin{array}{l}\text { HÁBITOS de } \\
\text { HIGIENE e SAÚDE }\end{array}$ & $\begin{array}{l}\text { CRESCIMENTO } \\
\text { CORPORAL } \\
\text { (saúde física) }\end{array}$ \\
\hline \multirow{3}{*}{$\begin{array}{c}\square \\
\text { PSÍQUICA } \\
\text { (Mente racional) } \\
\square\end{array}$} & $\begin{array}{l}\text { INTELECTUAL } \\
\text { Inteligência }\end{array}$ & $\begin{array}{c}\text { SUSTENTAÇÃO } \\
\text { COGNITIVA } \\
\text { Necessidade de Saber } \\
\text { informações e conhecimento }\end{array}$ & $\begin{array}{c}\text { HÁBITOS } \\
\text { INTELECTUAIS } \\
\text { RACIONAIS }\end{array}$ & $\begin{array}{l}\text { CAPACIDADE DE } \\
\text { DISCERNIMENTO } \\
\text { (entre o bem e o mal) }\end{array}$ \\
\hline & $\begin{array}{l}\text { AFETIVO } \\
\text { Emoções, } \\
\text { Sentimentose } \\
\text { Paixões }\end{array}$ & $\begin{array}{c}\text { SUSTENTAÇÃO AFETIVA } \\
\text { (Estrutura emocional) } \\
\text { Necessidade de Sentir } \\
\text { segurança, tranquilidade, } \\
\text { autovalorização, autoconfiança, } \\
\text { realização, conforto emocional; } \\
\text { etc. } \\
\end{array}$ & $\begin{array}{l}\text { TITUDES Pessoais } \\
\text { FUNDAMENTAIS } \\
\text { (Virtudes pessoais) }\end{array}$ & $\begin{array}{l}\text { MATURIDADE } \\
\text { PSICOLÓGICA } \\
\text { (estabilidade } \\
\text { emocional) }\end{array}$ \\
\hline & $\begin{array}{c}\text { SOCIAL } \\
\text { Relacionamento } \\
\text { humano }\end{array}$ & $\begin{array}{c}\text { SUSTENTAÇÃO } \\
\text { RELACIONAL } \\
\text { Necessidade de Interagir } \\
\text { sentindo-se amado, protegido, } \\
\text { consolado, amparado; } \\
\text { compartilhando, etc. }\end{array}$ & $\begin{array}{l}\text { TITUDES Sociais } \\
\text { FUNDAMENTAIS } \\
\text { (Virtudes morais) }\end{array}$ & $\begin{array}{l}\text { INTER- } \\
\text { DEPENDÊNCIA } \\
\text { (independência } \\
\text { compartida) }\end{array}$ \\
\hline $\begin{array}{l}\text { NOOLÓGICA } \\
\text { (Alma) }\end{array}$ & $\begin{array}{c}\text { ESPIRITUAL } \\
\text { Vontade }\end{array}$ & $\begin{array}{c}\text { SUSTENTAÇÃO } \\
\text { VOLITIVA } \\
\text { Necessidade de Entender } \\
\text { (Razão) } \\
\text { Vontade de Sentido: } \\
\text { "realizar-se livremente } \\
\text { enquanto homem" } 30 \text { (SER } \\
\text { humano) }\end{array}$ & \begin{tabular}{|c} 
ATITUDES \\
Espirituais \\
FUNDAMENTAIS \\
(Virtudes teologais)
\end{tabular} & \begin{tabular}{|c} 
FELICIDADE \\
Plenitude (Condição \\
plenade satisfação) \\
Autêntica \\
manifestaçãodo \\
essencial humano 31
\end{tabular} \\
\hline
\end{tabular}


De acordo com Benigno Freire (2002a), o desenvolvimento humano está sujeito ao que ele chama de harmonia da alma. Se trata de um equilíbrio dinâmico que potencia cada faculdade, enquanto as cadencia e as une, constituindo um todo.

E a melhor maneira de se conseguir essa harmonia é, segundo o mesmo Freire, colocar a razão no comando sobre as outras dimensões humanas.

Platão (2000), alude sobre isso no Livro IX da República $\left(582^{\mathrm{a}}\right)$ : “Dissemosem qualquer altura que é com o raciocínio que se deve julgar". Os gregos antigos concebiam a "harmonia como beleza" (JAEGER, 1971, p. 163). E este conceito é também válido para se compreender o dinamismo humano no que diz respeito á suaunidade funcional e à sua coordenação. A antropologia de Karol Wojtyla, por exemplo, utiliza para esse entendimento, o "conceito de integração 32" (WOJTYLA, 1982, p. 334-346). Essa é a ideia central da visão clássica do homem, e, portanto,de sua ética:

Quando a alma inteira aceita a orientação da parte que ama a sabedoria (razão) e não está cheia de discórdia interior, é-lhe possível cumprir em tudo as suas funções e ser justa, e colher cada uma os prazeres que lhe são próprios, os de melhor qualidade e o mais verdadeiro possível [...] Mas quando é uma das outras partes (impulsos instintivo ou afetivo) que manda, não lhe é dado encontrar o prazer que lhe é próprio, e de mais a mais, força as outras partes air em busca de um prazer que lhe é alheio e que não é verdadeiro (PLATÃO, República, 586a-587ª 2000).

Segundo Freire (2002a), existem duas maneiras de se considerar a harmonia da alma: desde fora e desde dentro. A consideração externa indica que o único modo de se conseguir essa harmonia ou equilíbrio, acontece quando há um objetivo(skopós), que unifica as tendências; quando existe um fim ou objetivos predominantes que dão sentido a todas as ações. Alcançá-los significa atingir a autorealização, a plenitude e a felicidade.

A consideração da harmonia psíquica desde dentro precisa, em primeiro lugar, de acordo com Freire (2002a), que a pessoa esteja reconciliada com seu próprio inconsciente. Existe um certo preconceito - talvez devido em parte aos ensinamentos de Freud -, que esboça uma imagem equivocada do inconsciente como uma instância oculta, anárquica, que determina a conduta do indivíduo à sua revelia. Certamente, o inconsciente é importante, entretanto, não é o todo-poderosodo homem. É apenas um conjunto de elementos biológicos, genético, psicológicos, culturais, etc. que o homem carrega, quando pratica as suas ações conscientes. Freire chama esse conjunto de síntese passiva. E essa harmonia entre o

inconsciente e a vida consciente, é o que as pessoas emocionalmente saudáveis, normalmente, conseguem através de um processo educativo adequado.

O humanismo clássico e o Cristianismo, há séculos, determinam que é através da educação da vontade que o ser humano alcança a harmonia, o equilíbrio, a autorealização e, consequentemente, o 
amadurecimento pessoal. E que essa educação está baseada, fundamentalmente, no estímulo para a aquisição de hábitos bons - as virtudes, e ao mesmo tempo, no apoio no sentido de se resistir à tendência ${ }^{33}$ natural de se adquirir hábitos maus - os vícios e pecados.

Quadro 2 - As virtudes e os 7 pecados capitais

\begin{tabular}{|c|c|c|}
\hline Pecado & Virtude oposta & Descrição \\
\hline Soberba & $\begin{array}{l}\text { Humildade (em } \\
\text { latim, humilitas) }\end{array}$ & $\begin{array}{l}\text { Hábito característico da pessoa modesta. Opõe-se à vaidade. } \\
\text { Refere-se à qualidade daqueles que não se consideram } \\
\text { melhores do que ninguém. Respeito e consideração pelos } \\
\text { outros. }\end{array}$ \\
\hline Avareza & $\begin{array}{l}\text { Generosidade (em } \\
\text { latim, liberalis) }\end{array}$ & $\begin{array}{l}\text { Desprendimento e liberalidade. Hábito de dar sem esperar } \\
\text { receber em troca. Não se limita apenas aos bens materiais }\end{array}$ \\
\hline Gula & $\begin{array}{l}\text { Temperança }(\mathrm{em} \\
\text { latim, temperantia })\end{array}$ & $\begin{array}{l}\text { Autocontrole e moderação dos prazeres. Proporciona } \\
\text { equilíbrio eassegura o domínio da vontade sobre os } \\
\text { impulsos instintivos }\end{array}$ \\
\hline Inveja & $\begin{array}{l}\text { Caridade }(\mathrm{em} \\
\text { latim, caritas) }\end{array}$ & $\begin{array}{l}\text { Amor e compaixão. Atitude altruísta de ajudar o próximo } \\
\text { sembuscar qualquer tipo de recompensa }\end{array}$ \\
\hline Luxúria & $\begin{array}{l}\text { Castidad } e(e m \\
\text { latim, castitate) }\end{array}$ & $\begin{array}{l}\text { Comportamento voluntário de abstinência dos prazeres e da } \\
\text { prática de atos sexuais. Diz respeito aos prazeres sensuais. } \\
\text { E sensual não é necessariamente o mesmo que sexual. } \\
\text { Sensual é tudo aquilo que diz respeito aos cinco sentidos. } \\
\text { Sendo assim, } \\
\text { castidade é abstinência dos prazeres sensuais }\end{array}$ \\
\hline Ira & $\begin{array}{l}\text { Paciência (em } \\
\text { latim, patientia) }\end{array}$ & $\begin{array}{l}\text { Serenidade, calma e tranquilidade. Resistência às } \\
\text { influências externas e moderação da própria vontade. É a } \\
\text { capacidade de suportar os incômodos e as dificuldades, e } \\
\text { persistir em uma } \\
\text { atividade difícil, se libertando da tendência natural à } \\
\text { impaciência }\end{array}$ \\
\hline Preguiça & $\begin{array}{l}\text { Diligência (em } \\
\text { latín, diligentia) }\end{array}$ & $\begin{array}{l}\text { Presteza, decisão e empenho. Determinação e } \\
\text { perseverança emseguir um objetivo ou propósito de vida }\end{array}$ \\
\hline
\end{tabular}

Fonte: Orações do cristão (2001). Adaptação e organização da autora

Sendo assim, o caminho para alcançar-se essa harmonia, segundo Yepes; Aranguren (1999, p. 76), é através da ética; o que consiste em alcançar um ponto intermediário de equilíbrio entre os sentimentos e os impulsos biológicos, através dadeterminação da razão (vontade). "Para alcançar-se a harmonia, há de dirigir-se as diversas faculdades a um objetivo comum, do qual a razão é a encarregada de indicar".

Sávio Souza, citando Benigno Freire, esclarece que os "afetos ${ }^{34}$ são componentes necessários e substantivos da estrutura ontológica do ser humano. Não sendo bons ou maus em si mesmos, mas dependentes da orientação com que se empregue a racionalidade em seu controle" (SOUZA, 2010, p.89). 
A antiga tradição da filosofia clássica (grega), já entendia que o homem não só se diferencia do animal porque teria uma maior organização, ou especialização, ou sublimidade de vida, mas fundamentalmente, por estar dotado de razão ou logos. Este é, segundo Max Scheler (1964), o agente específico que diferencia o homem dos restantes dos animais. E é através da razão que os seres humanos são capazes de conhecer todas as coisas que o rodeiam no mundo, e também a si próprios. O homem pode agir livremente e escolher. E pode também, atuando na natureza, transformá-la e manipulá-la como quiser.

Torelló (1987) explica a diferença entre razão e inteligência, aproveitando a observação de uma situação extrema: o caso de uma pessoa paranóica. Essa toma,por exemplo, como premissa maior, como ponto de partida de vida, a ideia de que está sendo perseguida e de que todos estão conspirando contra ela. Essa ideia é radicalmente falsa, irracional, mas a partir dali o doente pode atuar de forma extremamente sagaz. Na tentativa de demonstrar a verdade de sua tese paranóica,é capaz de desenvolver às vezes construções mentais e concatenações lógicas tão convincentes que se torna difícil provar a irracionalidade de sua obsessão persecutória. Essa pessoa está louca, desprovida de razão - de fundamento - , maspode revelar uma grande inteligência.

Não é difícil encontrarmos nos dias atuais, homens e mulheres que, sem serem clinicamente diagnosticados como paranóicos, mantêm continuamente uma situação de ruptura entre a razão e a inteligência. Sua existência parece ajuizada mas carece de fundamento. É coerente, talvez, dentro de determinada esfera, mas não tem razão de ser, nem um sentido definitivo. É uma existência perifericamente inteligente mas profundamente irracional, como acontece na paranóia.

Nesse sentido, o professor Benigno Freire (2002b) esclarece que, desde o ponto de vista psicológico, a pessoa alcança a plenitude e a sua identidade, fundamentalmente, mediante a superação do próprio egocentrismo - fase natural na infância -, ultrapassando o estágio do ser servido para $o$ servir; do egoísmo à generosidade; da voracidade à entrega; ou seja, evoluindo-se da imaturidade ao amadurecimento interpessoal.

Eugene Minkowski, certo momento em uma de suas famosas meditações fenomenológicas, se dá conta de que "a vida foi feita para a entrega" 35 . Entretanto, esse dom de si, segundo Benigno Freire (2002b), que constitui-se em um encontrar-se ao invés de perder-se, costuma assustar as pessoas. Todavia, é preciso assumir os riscos, o risco que implica cada crescimento, cada progresso científico, cada criação artística, cada ato de amor, cada vida de fé. E, de fato, a mania ou necessidade exagerada de segurança, de bem-estar e de controle desmedido na vida, tende a paralisar o ímpeto vital e a realização do indivíduo: uma existência em conserva e covarde, segundo Torelló (1987), se torna inútil e pesada para a própria pessoa e para os demais; é como uma couraça ou armadura que sufoca. 
Viktor Frankl (1964) também neste sentido, explica que a neurose semprepõe em manifesto um modo equivocado de estar-en-el-mundo (estar no mundo), emcuja base existe uma pulsão egocêntrica, uma fixação do eu, que impede o seu progresso em direção à maturidade. Em contrapartida - completa Freire (2002b) -, a plena realização do indivíduo e o amadurecimento pessoal está intimamente ligadoà entrega e ao dom de $\mathrm{si}^{36}$.

Conclui-se portanto, que o sentido da vida está ligado ao serviço, e vai invariavelmente ao encontro do outro. O non serviam (não servir), por outro lado, subjuga e afasta as pessoas. O egocentrismo, segundo Torelló (1987), constitui-se como uma rebelião contra o fato de ser pessoa; como uma opressão, violação ou abuso contra à natureza humana.

Torelló continua, explicando que o homem, como toda criatura, é um ens ab alio: um ser por outro, para o outro, no outro. E seu pecado original consiste em querer ser ens a se: por si mesmo, ser Deus ("sereis como deuses" [Gn 3, 5], prometeu a serpente no Paraíso). O egoísmo está, fatalmente, na origem de qualquer pecado. "O amor desordenado a si mesmo é causa de todo pecado", assegura São Tomás de Aquino (ST I q.84, a.2).

O egocêntrico sofre com a falta de liberdade interior. Ele é escravo de seu impulso desmedido e insano de salvaguardar o próprio eu, fugindo de qualquer coisa, pessoa ou situação que o ameace. Sozinho e isolado, ele vai em busca apenas daquilo que o tranquiliza. Torelló (1987), diz que a atitude primordial do egocêntrico é fugir de qualquer tipo de sacrifício ou sofrimento. Entretanto, C.S. Lewis (2001), adverte que uma pessoa nunca será feliz, fugindo do sofrimento: uma coisa está atrelada a outra. Quem não está disposto a sofrer dificilmente alcançará afelicidade. E Torelló completa, alertando que o verdadeiro caminho para a felicidadeé em direção ao outro, ao serviço e ao amor.

O homem individualista vive numa atmosfera angustiante, se equilibrando na corda bamba, preocupado consigo mesmo, permanece afastado da realidade. Por outro lado, a pessoa realista, objetiva e madura, é fundamentalmente elástica e adaptável às contingências da vida, mantendo sempre em mente os fins essenciais da existência e o sentido da sua vida.

Devemos estar sempre atentos que a atitude egocêntrica escraviza, vicia as nossa percepções e ofusca a nossa visão da realidade, e consequentemente, dificulta as nossas ações. Adler (1956) fala de percepção tendenciosa e Künkel (1984), de óculos egocêntricos, que não só ajudam ao egocêntrico a fugir da realidade, como corroboram para atitudes e concepções de vida artificiais.

A origem do egocentrismo está, muitas vezes, no erro educativo. Uma criança pequena, explica Künkel (1984), sentada no chão, constrói uma torre com cubos de madeira. Vem a mãe e se alegra ao ver a construção. Entretanto, ela não enaltece a beleza da torre, mas sim a habilidade do filho. Esse desvio (egótico) materno estimula a criança, porém muda a polaridade de seus esforços: ele já 
não tenderá a trabalhar objetivamente, por amor à criatividade, pela satisfação de realizar um trabalho bem feito mas, simplesmente, para receber um elogio e se tornar o centro das atenções.

Imaginemos que essa torre desabe, se a criança for objetiva e realista, insistirá no trabalho, tratará de melhorá-lo, pensaria em uma maneira mais eficaz para sua construção, até descobrir o segredo da estabilidade. Assim, de uma experiência negativa surgiria outra positiva e a criança teria dado um passo adiante em direção ao seu amadurecimento. Mas, se a criança tiver tendência ao egocentrismo, ela irá chorar e se aborrecer, esperando que a mãe venha em seu socorro. E essa pode ser uma intromissão muito perigosa: a mãe sentada no chão, fazendo o que o filho teria condição de fazer por conta própria. Com isso o filho vai aprendendo que as crianças, como ele, são incapazes (assim começa o complexo de inferioridade); que não são capazes realizar - tornar real - seus desejos e sonhos; e que é mais fácil deixar que os outros se esforcem por conseguir um bom resultado. Pensando assim, essa criança tornar-se-á um adulto insatisfeito, provavelmente, com dificuldade de se sentir realizado, bem-sucedido e feliz.

Da mesma forma, o egoísmo também pode ser estimulado pela falta de tato ou erro educativo. Quando a criança se habitual a ser servida, quando as suas necessidades são prontamente atendidas, mesmo antes delas existirem, essapessoa crescerá permanecendo iludida de que os outros existem para servi-la,viverá com a ilusão de que ela é o centro do universo e que tudo gira em torno do seu horizonte e da sua perspectiva egocêntrica e infantil.

Torreló (1987) explica que para que a relação educativa seja conveniente e proveitosa - assim como em todo tipo de relação humana saudável -, ela deve estarbaseada no que ele chama de intercâmbio relacional, onde uma pessoa ajuda a outra como uma manifestação de amor mútuo. E, para que essa relação seja harmônica, deve haver uma sincronia adequada entre ambas as partes envolvidas no relacionamento.

Assim, por exemplo, como acontece na performance de dois patinadores se apresentando em um espetáculo de balé no gelo: os movimentos devem ser absolutamente sincronizados, tornando a apresentação correta, harmoniosa e bela. Cada um desempenhando o seu papel, interagindo um com o outro, conseguem realizar manobras que o patinador sozinho, nunca conseguiria. Nesse caso são necessárias duas pessoas atuando, com um objetivo comum: executar uma coreografia em conjunto. Algumas vezes será preciso muito tempo de treino e dedicação antes de se consegui a performance que satisfaça a todos.

Por outro lado, aproveitando o mesmo exemplo, podemos imaginar umaapresentação onde os dois patinadores não conseguem essa sincronia. Onde cada um está preocupado com a sua própria atuação, apresentando manobras individuais, não consegue interagir com o outro. Dessa forma - cada 
um empenhado na sua performance pessoal -, acabam, os dois, apresentando um espetáculo sem sincronia onde a harmonia se perde, tornando a exibição grotesca esem encanto.

Muitas vezes essa falta de sincronia pode acontecer na nossa vida. Quando nos deixamos levar pela vaidade e o sentimento de autosuficiência, com a ilusão de que não precisamos de ninguém que nos apóie, acabamos nos desequilibrando e não conseguindo executar aquele movimento desejado.

Esta é a ocasião onde a direção espiritual pode ser muito conveniente, nos ajudando a enxergar o que não está bem ou o que estamos fazendo errado, nos apontando o caminho quando nos sentimos perdidos.

Assim, nesses momentos de desorientação e aflição, as pessoas encontram na direção espiritual aquela palavra animadora, inspirada pelo Espírito Santo, comouma lâmpada que ilumina os caminhos na vida das pessoas.

A palavra, segundo São Josemaría Escrivá (1977, n. 298), “é um dos dons mais preciosos que o homem recebeu de Deus, dádiva belíssima para manifestar altos pensamentos de amor e de amizade ao Senhor e às suas criaturas". E é valendo-se dessa palavra que o diretor/a espiritual aconselha, anima e orienta o caminho em direção á felicidade e à paz.

Concluímos, lembrando as palavras do Papa João Paulo I, enquanto eraainda o Cardeal Luciani: "Descubro que a minha pessoa se enriquece através da conversação. Porque possuir sólidas convicções é belo; mas, mais belo ainda, é poder comunica-las e vê-las compartilhadas, apreciadas e vividas pelos outros" ${ }^{\prime 37}$.

\subsection{A NATUREZA DO ACOMPANHAMENTO ESPIRITUAL}

Na Revelação Bíblica encontramos a promessa de Deus feita aos homens e às mulheres de que não ficariam órfãos e seriam guiados pelo Espírito Santo. Na história da Igreja, verificamos como homens e mulheres tornam-se instrumentos, mediadores no discernimento da vontade de Deus. Portanto, a direção espiritual parte da intuição fundamental de que Cristo age invisivelmente por meio do Espírito na Igreja, e de que, em cada cristão realiza-se a obra do Espírito de Deus. Desse modo, a mediação eclesial revela-se com uma aspecto sobrenatural e, ao mesmo tempo, reveste-se de um profundo sentido humano. "Pede sempre conselho ao homem sábio" (Tob 4, 19), conforme diz a Sagrada Escritura.

Para pedir conselho sobre uma matéria ou uma preocupação de natureza meramente humana, talvez bastasse escolher quem fosse capaz de compreender melhor o problema ou a situação difícil enfrentada e que fosse uma pessoa com mais experiência, compreensiva e discreta.

Mas, para tudo o que se refere de algum modo à alma e a uma ordem superior, requer-se especial finura de espírito para saber com quem Deus quer que nos abramos. Porque, se tomarmos em 
consideração apenas fatores humanos, corremos o risco de que não nos entendam nem compreendam; e então a alegria de termos aberto a alma torna-se amargura; e a amargura desemboca emincompreensão que não alivia; e em qualquer caso experimenta-se o desassossego, o íntimo mal-estar de quem falou demasiado, com quem não devia, daquilo que não devia (SUÁREZ, 1983, p.89-90).

Para o desenvolvimento e o progresso na vida espiritual é necessário, segundo Torelló (1987), ter-se em mente o objetivo claro - seguir Cristo e o Evangelho -, com algumas metas concretas a serem alcançadas. E, principalmente, conhecer-se nitidamente os meios mais adequados e seguros para colocar-se no caminho, enfrentando todas as dificuldades e obstáculos que encontrar pela frente.

No entanto, como já foi lembrado anteriormente, é muito difícil guiar-se por conta própria com relação ao progresso na vida interior. Quantas vezes a falta de objetividade com que a pessoa se percebe, o amor próprio, a tendência por deixar- se levar pelo mais fácil ou o mais prazeroso, vão dificultando o desenvolvimento pessoal.

O ser humano tem uma necessidade natural de proteção, de amparo e de consolo. E não apenas as crianças pequenas, que buscam amparo no colo da mãe, mas também o adulto e os mais idosos têm necessidade de se sentirem seguros e protegidos. No trabalho, nos relacionamentos, na família, etc., o ser humano vai precisar de apoio e acolhimento durante toda a sua existência. E a privação dessa necessidade, principalmente nos cinco primeiros anos de vida, pode causar muitos danos e gerar consequências desastrosas para o desenvolvimento da personalidade do indivíduo.

Diferente de alguns outros animais, o homem nasce numa situação de total dependência ${ }^{38}$, tanto física como emocional. Por um longo período de tempo ele irá pessoais; Interdependência: Relação com depender de uma outra pessoa, até ser capaz de satisfazer as suas necessidades por conta própria e poder sobreviver com uma certa independência.

Entretanto, existem algumas necessidades que não podem ser satisfeitas sea pessoa estiver só. As pessoas têm necessidade de sentirem-se amadas, protegidas e consoladas. É latente a necessidade de doar ${ }^{39}$. Consciente ou inconscientemente, as pessoas se sentem satisfeitas ajudando o outro, compartilhando. Lembrando uma entrevista do magnata grego Aristotle Socrates Onassis ${ }^{40}$, concedida pouco antes de sua morte em 1975, a um jovem repórter inglês, ele dizia:

O que me adianta ter tantas coisas?[...] tantos bens materiais, tanto dinheiro, tanto luxo? [...] o quê me adianta tudo isso, se não tenho com quem compartilhar. Eu demorei para entender que é muitomelhor, trás muito mais satisfação, dividir um só prato de lentilhas com uma pessoa que se ama, do que desfrutar de um laudo banquete sozinho (PETER, 1986, p. 113).

Esta é uma observação frequentemente lembrada na direção espiritual: Se uma pessoa não tem com quem compartilhar a vida - seus bens materiais, suas alegrias, suas tristezas -, e não se sentir útil, 
de alguma maneira, na vida de um outro, facilmente se sentirá insatisfeita, abatida e provavelmente infeliz.

O que muitas vezes acontece, é que algumas pessoas confundem a origem da sua insatisfação. Essas pessoas não conseguem entender porquê se sentem tãoangustiadas e vazias. Muitas vezes vão procurar ajuda na psicoterapia, queixando- se não conseguir compreender de onde vem tanto descontentamento, sequestionando como é possível para uma pessoa que tem “tudo" - saúde, um bom emprego, bastante dinheiro, etc., se sentir tão angustiada e infeliz. Sem ajuda, provavelmente, essa pessoa não terá condição de perceber que a sua insatisfação está na alma. E o que ela mais precisa é se sentir amparada, segura e protegida.

Torelló, em um de seus artigos intitulado La espiritualidad de los laicos, se refere à Igreja Católica como "o regaço materno que protege e nutre" 41 , um lugar onde as pessoas se sentem acolhidas e seguras. Nesse mesmo artigo, Torelló continua, explicando que a angústia humana nasce, exatamente, da falta dessa sensação de resguardo, conforto e segurança.

João Paulo II, em uma carta aos seminaristas da Espanha, falando sobre as dificuldades e percalços que encontramos na vida, alertava: "Este é o momento da direção espiritual pessoal. Falandose com confiança, expondo-se com naturalidade as próprias lutas interiores, salta-se sempre adiante, e não existirão obstáculos nemtentações que consiga afastá-los de Cristo” (Valência 8-XI-1982).

Bento XVI, em 2007, explicando sobre a importância da direção espiritual, também alertava:

A vida é como uma viagem pelo mar da história, com frequência, sombrio e tempestuoso. Uma viagem na qual consultamos os astros que nos indicam o caminho. As verdadeiras estrelas da nossa vida são as pessoas que tem sabido viver retamente. Elas são luzes de esperança. Jesus Cristo é, certamente, a luz por excelência, o sol que brilha sobre todas obscuridades da história. Mas para chegar à Ele, necessitamos de luzes que estejam próximas, pessoas queirradiam luz, refletindo a luz de Cristo, oferecendo assim, orientação para a nossa travessia (Bento XVI, Spe salvi, 30-XI-2007, n. 49).

Portanto, a direção espiritual não deve ser confundida com psicoterapia $^{42}$, consultoria ou com uma simples conversa fraterna. O diretor/diretora espiritual é aquele guia cauteloso que mostra com alguns conselhos práticos e, principalmente, com o seu exemplo de vida, o caminho que Deus espera que cada um percorra, a vocação pessoal de cada indivíduo em particular, com suas habilidades e suas limitações, nas condições reais e o ambiente concreto em que se encontra.

Recentemente o Papa Bento XVI, no discurso comemorativo aos 75 anos da Faculdade Pontifícia Teresianum de Roma, destacou a importância do acompanhamento espiritual para todo cristão que quer viver com responsabilidade oseu próprio Batismo: 
Como sempre tem feito, inclusive nos dias de hoje, a Igreja vem recomendando a prática da direção espiritual, não só aos que desejem seguir Cristo de perto, mas a todo cristão que quer viver com responsabilidade o próprio Batismo [...] Todos, de fato, e de modo particular os que acolheram o chamado divino para segui-Lo mais de perto, precisam estar acompanhados de um guia seguro na doutrina e um especialista nas coisas de Deus, que pode ajudar a defender-se de subjetivismos fáceis, colocando à disposição seus conhecimentos e experiências no seguimento de Jesus [...] Trata-se de instaurar a mesma relação pessoal que o Senhor tinha com seus

discípulos, o laço especial com que Ele os conduziu, no seu seguimento, para abraçar a vontade do Pai [...] Também vós, queridos amigos, na medida em que sejais chamados a este dever insubstituível, fazei um tesouro de tudo o que aprendestes durante estes anos de estudo, para acompanhar todos os que a Providência vos confiar, ajudando-os no discernimento dos espíritos e na capacidade de seguir os impulsos do Espírito Santo, com o objetivo de conduzi-los à plenitude da graça até alcançar a medida da plenitude de Cristo (http:;;www.zenit.org;).

A Tradição da Igreja parte do pressuposto básico de que Deus, de alguma maneira, dirige-se aos homens para ajudá-los, agindo algumas vezes diretamente na alma e outras, por meio de outra pessoa que será como que um canal ou instrumento da sua graça.

Alegre-se o coração dos que buscam o Senhor! (S1 105,3). Se o homem pode esquecer ou rejeitar a Deus, este, de sua parte, não cessa de chamar todo homem a procurá-lo, para que viva e encontre a felicidade. Mas essa busca exige do homem todo o esforço da sua inteligência, a retidão da sua vontade, “um coração reto", e também o testemunho dos outros, que o ensinam a procurar a Deus. (Catecismo da Igreja Católica I, 30).

De acordo com Fernández-Carvajal (2011, p. 6): “O Espírito Santo dá a certos fiéis o dom da sabedoria, da fé e do discernimento dirigidos a esse bem comum que é a direção espiritual. Aqueles e aquelas que foram dotados de tais dons são verdadeiros servidores da tradição viva da oração".

São Gregório Magno chama essa missão de guiar os outros, “El arte de las artes”, e São Francisco de Sales, "El consejo de los consejos" 43 . Se trata de "um meio clássico que não perde o seu valor" (Pastores dado vobis, 40). João Paulo II reiterando a sua observação, nessa mesma Exortação Apostólica, lembra que:

É preciso redescobrir a grande tradição do acompanhamento espiritual pessoal, que sempre deu tantos e tão preciosos frutos na vida da Igreja: esse acompanhamento pode, em determinados casose em condições bem precisas, ser ajudado, mas não substituído, por formas de análise ou de ajuda psicológica. As crianças, os adolescentes e os jovens sejam convidados a descobrir e a apreciar o dom da direção espiritual, e a solicitá-lo com confiante insistência aos seus educadores na fé. Os sacerdotes, pela sua parte, sejam os primeiros a dedicar tempo e energias a esta obra de educação e de ajuda espiritual pessoal: jamais se arrependerão de ter transcurado ourelegado para segundo plano muitas outras 
coisas, mesmo boas e úteis, se for necessário para o seu ministério de colaboradores do Espírito na iluminação e guia dos chamados (Pastores dado vobis, 40).

E em seguida, no mesmo documento, citando o Cardeal Montini, futuro PauloVI, o João Paulo II continua, explicando sobre a importância e a necessidade do acompanhamento espiritual para todas as pessoas:

\begin{abstract}
Também a prática da direção espiritual contribui muito para favorecer a formação permanente dos sacerdotes. É um meio clássico, que nada perdeu do seu precioso valor, não só para assegurar a formação espiritual mas ainda para promover e sustentar uma contínua fidelidade e generosidade no exercício do ministério sacerdotal. Como então escrevia o futuro Papa Paulo VI, "a direção espiritual tem uma função belíssima e pode dizer-se indispensável para a educação moral e espiritual da juventude que queira interpretar e seguir com absoluta lealdade a vocação da própria vida,seja ela qual for, e conserva sempre uma importância benéfica para todas as idades da vida, quando à luz e à caridade de um conselho piedoso e prudente se pede a comprovação da própria retidão e o conforto para o cumprimento generoso dos próprios deveres. É meio pedagógico muito delicado, mas de grandíssimo valor; é arte pedagógica e psicológica de grande responsabilidade para quem a exercita; é exercício espiritual de humildade e de confiança para quem a recebe (Pastores dado vobis, 81).
\end{abstract}

Assim, a direção espiritual tem sido sempre um meio seguro para os que verdadeiramente almejam alcançar a santidade. Francisco Fernandéz-Carvajal, sacerdote contemporâneo espanhol e autor de diversos livros de espiritualidade, afirma que a direção espiritual torna-se necessária por muitos motivos:

Primeiro, para que não tenhamos que dizer no final da nossa vida -e até antes - o que disseram os judeus depois de vagarem pelo deserto sem rumo nem sentido: 'Durante quarenta anos demos volta nas montanhas' (Dt 2,1). Fomos vivendo sem saber para onde íamos, sem que o estudo ou o trabalho nos aproximassem de Deus, sem que as amizades, o lazer, a família nos ajudassem a dar um passo adiante no que verdadeiramente importa: a felicidade que não passa, a salvação. E também para que não tenhamos que reconhecer que vivemos entretidos com bugigangas. E tudo por nos ter faltado uma meta clara que unificasse e desse continuidade aos nossos esforços e sacrifícios, um norte claro e apaixonante para o qual nos dirigirmos (FERNANDÉZ-CARVAJAL, 2003, p. 19).

Quem realmente deseja encontrar o seu caminho, aproximando-se e fazendo a vontade de Deus, sabe da necessidade de amparar-se na experiência de outra pessoa que estimule, incentive e mostre com objetividade e imparcialidade, desde fora, orientando e esclarecendo, como um autêntico colaborador do Espírito Santo.O verdadeiro diretor espiritual deve estar ciente de que a sua missão é, como a de João Batista, encaminhar os seus discípulos ao Senhor (Jo 1, 29-37).

Tanquerey (1961, p. 263), citando Libermann, explica que o diretor espiritual não é mais do que um instrumento a serviço de Espírito Santo: "Este deve pois, aplicar-se antes de mais nada a 
conhecer, por meio de perguntas discretas, a ação deste divino Espírito na alma”. E continua, explicado sobre a função do diretor espiritual:

Discernir em cada alma as disposições que nela há... o que pode suportar o estado interior desta alma; deixar operar a graça com grande liberdade, distinguir as falsas inspirações das verdadeiras, e impedir que as almas se extraviem ou excedam nessas aspirações. O diretor, uma vez que tenha visto e discernido a operação de Deus numa alma, não tem outra função mais que guiar essa alma, para que ela vá seguindo a graça e lhe seja fiel... Jamais deve querer inspirar a uma alma os seus próprios gostos e atrativos, nem guia-la segundo a sua maneira de proceder ou de ver as coisas. Um diretor, que assim procedesse, afastaria muitas vezes as almas da direção de Deus e contrariaria muitas vezes nelas a graça divina (TANQUEREY, 1961, p. 263).

Entre os meios externos de santificação, de acordo com o dicionário de espiritualidade de Ermanno Ancilli, o acompanhamento espiritual ocupa um lugar fundamental. Encontramos aqui a definição de direção espiritual como "a ciência e aarte de conduzir as almas à perfeição cristã”. Quanto ao objetivo e finalidade da direção espiritual, este autor se refere ao progresso da vida interior e a santidade. E continua, discorrendo acerca dos princípios que regulam esta prática: os teológicose os psicológicos (ANCILLI, 1987, p. 618).

Royo-Marín (1994, p. 808), no mesmo sentido, define direção espiritual como "a arte de conduzir as almas progressivamente desde o começo da vida espiritualaté o ápice da perfeição cristã". Explicando cuidadosamente essa definição, o autor esclarece cada uma de suas afirmações. Inicialmente ele explica porque consideraa direção espiritual uma arte:

“A arte..." - Empregamos essa expressão em um sentido puramente metafórico. Na realidade, a técnica da direção espiritual se constitui em uma verdadeira ciência prática. Entretanto, a consideramos como arte, toda vez que tendo como finalidade elevar-se ao céu uma espécie de edifício sobrenatural, que é o objeto próprio da arte (ROYO-MARÍN, 1994, p. 808).

Em seguida, o mesmo autor, continua esclarecendo a sua definição:

“... de conduzir as almas...” - A direção espiritual é eminentemente dinâmica e orientadora.
Tem como objeto mostrar as almas o verdadeiro caminho para chegar-se a união com Deus
[...] incumbe ao diretor traçar-lhe a rota que deverá seguir em cada momento da sua vida
espiritual. Não se trata de empurrar, mas de conduzir suavemente, respeitando a liberdade
das almas.
“... progressivamente...” - O caminhar deve ser firme e sem rodeios nem desvios. Mas
também sem saltos nem precipitações imprudentes. O diretor deve conduzir a alma
gradual e progressivamente, não exigindo-lhe mais do que a alma pode dar, deacordo com
as graças que Deus vai derramando sobre ela.

“... desde do começo da vida espiritual...” A direção deve começarimediatamente quando a alma, com o impulso da graça, se decide aempreender o caminho da perfeição cristã. Em todas 
as etapas desse caminho há uma infinidade de obstáculos e dificuldades, que, segundo a providencia ordinária de Deus, não se poderão superarsem a vigilância e uma adequada ajuda de um diretor espiritual. “...até o ápice da perfeição cristã...” - É o objetivo ou finalidade última da direção espiritual. O diretor deve orientar todas as energiasda alma até a sua plena e íntima união com Deus, ou seja, até oauge da santidade. Um diretor pouco consciente e medroso - comodiria Santa Tereza -, que se contente em manter as almas em umavulgar mediocridade e não a estimule, sem descanso, à perfeiçãocada vez maior, causará grande dano e encorreará em uma graveresponsabilidade perante Deus (ROYO-MARÍN, 1994, p. 808-809).

De acordo com Tanquerey, São Francisco de Sales ensinava que:

O diretor espiritual deve possuir três qualidades fundamentais: é preciso que ele seja cheio de caridade, ciência e prudência: A caridade como uma afeição sobrenatural e paterna, que lhe faz ver nos seus dirigidos, filhos espirituais, que lhe são confiados pelo próprio Deus, para que ele faça crescer neles Jesus Cristo e as suas virtudes; A ciência como o conhecimento da teologia ascética, da leitura dos Autores espirituais e dos Santos; E sobretudo, a prudência e sagacidade, para dirigir as almas, não segundo suas próprias ideias, mas segundo os movimentos da graça, o temperamento e o caráter do orientado, e as suas inclinações sobrenaturais (TANQUEREY, 1961, p. 261-263).

Continuando, sobre a necessidade da direção espiritual no encaminhamento das almas, Tanquerey cita Godinez com as seguintes palavras:

\begin{abstract}
Sobre mil pessoas que Deus chama à perfeição, dez apenas correspondem, e sobre cem que Deus chama à contemplação, noventa e nove faltam ao chamamento [...] devemos reconhecer que uma das principais causas é a falta de mestres espirituais [...]. Eles são, depois da graça de Deus, os pilotos que guiam as almas por este mar desconhecido da vida espiritual. E se é certo que não há ciência ou arte, por simples que seja, que se possa aprender bem sem um mestre que o ensine, muito menos se poderá aprender esta alta sabedoria da perfeição evangélica, em que se encontram mistérios tão profundos [...]. É este o motivo por que eu tenho por coisa moralmente impossível que, sem milagre ou sem mestre, uma alma possa durante longos anos atravessar o que há de mais elevado e árduo na vida espiritual sem correr perigo de se perder (TANQUEREY, 1961, p. 258-259).
\end{abstract}

Alguns Papas, também, desde os antigos até os atuais, costumavam recomendar fortemente o acompanhamento de um bom diretor espiritual para todos, tanto para as pessoas leigas como para os religiosos e religiosas consagrados.

No Séc. XIX, Leão XIII, já advertia com bastante veemência:

Convence-te de que não és um bom conselheiro de ti mesmo e, por isso, tema e desconfie das tuas opiniões, que tem uma raiz má e corrompida. Com essa persuasão, busca o conselho, dentro do possível, de homens sábios e de boa consciência, e prefira ser governado por alguém que seja melhor que tu a seguir teu próprio parecer (LEÓN XII, 2006, n. 28). 
O mesmo Leão XIII continua, ressaltando a necessidade da direção espiritual na carta Testem benevolentiae ao Cardeal Gibbons em 22 de janeiro de 1899:

Ninguém pode duvidar de que o Espírito Santo trabalha secretamente nas almas justas e as incita com exortações e impulsos; se não fosse assim, toda ajuda, todo adestramento externoseria inútil [...] Entretanto - e sabemos por experiência própria -, essas exortações, esses impulsos do Espírito Santo, quase nunca sepercebem sem a ajuda e a orientação do magistério externo [...] Deus providentíssimo, como quis que os homens em geral fossem salvos por meio de outros homens, também estabeleceu que todosos que aspiram aos mais altos graus da santidade, os alcancem por meio, também, de outros homens. Esta tem sido sempre, a norma daIgreja (ANCILLI, 1987, Tomo I, p. 621).

Cinquenta anos mais tarde, também sobre a importância do acompanhamento espiritual, o Papa Pio XII ressaltava:

No caminho da vida espiritual não confie em vos mesmos, mas com simplicidade e docilidade, peça conselho, e aceite ajuda de quem possa guiar vossa alma com esclarecida direção, indicar-vos os perigos, sugerir-vos os remédios oportunos e em todas as dificuldades, internas e externas, vos possa dirigir a uma perfeição cada vez maior, segundo o exemplo dos santos e os ensinamentos da ascética cristã. Sem esse prudente guia da consciência, é assaz difícil, pelas vias ordinárias, secundar convenientemente os impulsos do Espírito Santo e da graça divina (Pio XII, 1950, Menti nostrae).

Sem dúvida, a graça divina potencializa os talentos humanos da pessoa que exerce a função de diretor espiritual e, ao mesmo tempo, prepara o coração de quem recebe o conselho (FERNANDEZCARVAJAL, 2011). E, essa ajuda sobrenatural, é a primeira coisa que se deve conseguir do Senhor que, de sua parte,nunca quis prescindir do humano, como o fez, aproveitando os poucos pães e os peixinhos disponíveis quando alimentou mais de cinco mil homens no milagre da multiplicação (Mt $15,32)$.

As obras realizadas através da direção espiritual, devem ser atribuídas não à pessoa do diretor ou diretora, mas ao verdadeiro Artista; a gloria e a beleza do quadro pertencem ao pintor, não ao pincel. "Nós somos, verdadeiramente, o que é opincel nas mãos do grande Artista" (ESCRIVÁ, 1999, n. 612). Essa humildade, de sentir-se apenas instrumento, é manifestada pelo empenho em conduzir os outros exclusivamente pelos caminhos que o Espírito Santo indica, pois é Ele o verdadeiro guia das consciências. E para que o pincel seja realmente útil nas mãos do pintor, ele deve ter uma boa empunhadura e estar bem unido às mãos do mestre. Se não houver essa união, se o pincel não contribui firmemente aos impulsos que recebe doartista, não existirá arte.

Ser instrumento, portanto, no acompanhamento espiritual, é transmitir fielmente as inspirações e o espírito de Deus e não se deixar levar pelas fraquezas pessoais e as limitações próprias dos defeitos humanos. Assim, a sublime missãodo diretor espiritual, de acordo com a definição de Fiores (1989, p. 872), é: 
Aconselhar com base na realidade; orientando às pessoas que a ele se confiam, com a sua ciência e a sua experiência pelos autênticos caminhos que levam a Deus; promovendo o amadurecimento na fé, uma fé segura, explicita e atuante; favorecendo esse desenvolvimento com os meios humanos naturais, e também os sobrenaturais. $\mathrm{O}$ importante é utilizá-los para os dinamismos próprios da pessoa e das situações particulares em que ela se encontra. E, já que cada idade, cada geração e cada sociedade têm suas próprias exigências, o diretor espiritual terá que sentir-se obrigado a aplicar de formas sempre novas e adequadas os meiosde sempre e a conceber e experimentar incessantemente novos meios.

\subsection{PSICOTERAPIA E DIREÇÃO ESPIRITUAL}

Tão estreitas quanto sutis são as relações entre a psicoterapia e a direção espiritual. Daí a importância da necessidade de uma ponderada diferenciação euma correta caracterização dessas duas práticas, ambas a serviço da pessoa que está em busca de ajuda.

De uma forma esquemática podemos apresentar as seguintes considerações:

1. O psicoterapeuta é um médico, preferivelmente, ou um psicólogo especializado, cujo trabalho consiste em colocar em ordem uma existência pessoal deteriorada, esclarecendo e ampliando as relações do paciente consigo mesmo, com os outros e com o mundo.

O diretor espiritual tem uma missão distinta: é um médico ou psicólogoapenas em sentido análogo, não unívoco. A ele compete abrir, estreitar e aprofundar as relações com Deus, com Cristo e com seu Corpo, que é a Igreja, independentemente da pessoa ser saudável ou doente.

2. O psicoterapeuta, enquanto tal, trabalha no âmbito natural. Tendo como finalidade básica a saúde psíquica - o alivio das angústias, o controle e o equilíbrio emocional e o ajuste do comportamento, visando a integração adequada na comunidade familiar, profissional e social do paciente.

O diretor espiritual deve prestar a atenção, sobretudo, ao sobrenatural: à vontade de Deus a respeito do indivíduo. E à ação da graça, que pode manifestar- se diferentemente em cada um, tanto através da alegria como do sofrimento.

O diretor espiritual orienta e conduz no sentido da santidade, ou seja, se encarrega de promover o desenvolvimento espiritual da pessoa, incitando-a a alcançar a plenitude e perfeição na caridade.

3. A respeito da culpa moral, o psicoterapeuta tentará diferenciá-la dos sentimentos doentios de culpabilidade e dos complexos que devem ser eliminados.

Por sua parte, o diretor espiritual não só retificará o peso real das faltas morais cometidas, como também, estimulará a luta por superá-las e, sobretudo, animará à união e confiança em Deus, com a necessária docilidade e acolhida ás inspirações do Espírito Santo, que é o elemento decisivo no caminho em direção à santidade pessoal. Dessa maneira, o diretor espiritual não só ajudará no sentido de melhora do comportamento e no cumprimento dos deveres individuais, como facilitará o impulso em direção ao desenvolvimento da espiritualidade e da plenitudena vida cristã. 
4. Finalmente, o psicoterapeuta cuida dos que crêem e também dos que não crêem. Ao diretor espiritual, na maioria das vezes, se encaminham os fiéis que desejam ser apoiados e orientados com a finalidade de poder viver a sua crença da melhor maneira possível. Sendo assim, o psicoterapeuta não deve substituir odiretor espiritual; e vice-versa. Apesar do fato de que muitos neuróticos encontram na direção espiritual uma grande ajuda - sobretudo se o diretor espiritual é um sacerdote e tem alguma formação psicológica; e de que uma boa confissão, algumas vezes, leva à metanóia ${ }^{44}$ ou conversão, que indiretamente ataca o núcleo central de muitas neuroses. Deve-se entender que normalmente a direção spiritual não alcança o recurso para se tratar um distúrbio neurótico. Além disso, se o diretor espiritual não está, pelo menos, familiarizado com algum procedimento ou técnica psicoterapêutica, pode inclusive piorar e realimentar em um paciente neurótico, a sua patológica atitude vital (FRANKL, 1964).

\section{PESQUISA QUALITATIVA EM PROFUNDIDADE}

Com a intenção de atingir o objetivo proposto - investigar a influência da direção espiritual no processo de desenvolvimento da espiritualidade feminina -, optamospor desenvolver esse trabalho utilizando a metodologia de pesquisa qualitativa do tipo exploratória analítica ${ }^{45}$, por se tratar de um fenômeno concentrado na experiência humana dentro de um cenário natural (diferente de um laboratório).

Desenvolvemos o método de pesquisa de acordo com Parse, Coyne e Smith (1985), envolvendo cinco procedimentos básicos: identificação do fenômeno; estruturação do estudo; organização dos dados; análise dos dados e apresentação dos resultados.

As atividades de pesquisa dessa abordagem refletem as crenças apresentadas previamente a respeito da importância do contexto, explorando todas as dimensões da singularidade humana e ajudando a entender o sentido da experiência vivida por cada um dos sujeitos investigados, à medida que essas pessoas interagem no cenário social em resposta às circunstâncias da vida.

O trabalho teve início com a coleta de dados - por meio de observações e entrevistas -, que posteriormente foram reunidos, construindo-se uma espécie de mosaico ${ }^{46}$, ou quadro da experiência humana estudada. Assim, a síntese final que veio à tona a partir dos depoimentos dos participantes, surgiu dos indícios oriundos dos discursos dos sujeitos, passando pelas observações e interpretações da pesquisadora até a composição final apresentada em sete grandes temas. Pretendeu-se assim, transmitir de um modo coerente, o sentido complexo daspercepções subjetivas que permeiam a experiência vivida por cada um dos sujeitos envolvidos na investigação e oferecer uma visão geral como em um mosaico -, dasconsequências e dos benefícios práticos da direção espiritual na vida dessas pessoas. 


\section{SUJEITOS E INSTRUMENTOS DE PESQUISA}

Para levar a cabo as entrevistas, selecionamos um grupo de nove mulheres católicas com idade entre 35 e 62 anos, que estão recebendo ou já receberam, acompanhamento regular de um diretor espiritual. Todas são mulheres casadas quevivem em casa própria na cidade de Curitiba-PR/BR.

A seguir, apresenta-se um quadro explicativo com as características mais marcantes das pessoas investigadas, observadas pela pesquisadora no decorrerdas entrevistas. Os sujeitos são identificados por codinomes que tem relação com a personalidade de cada participante.

Quadro 3 - Características dos sujeitos investigados

\begin{tabular}{|c|c|c|c|c|c|}
\hline Suj. & Codinome & Idade & Filhos & Características pessoais & $\begin{array}{l}\text { Anos de } \\
\text { D.E }\end{array}$ \\
\hline 1 & TÍMIDA & 45 & 8 & $\begin{array}{l}\text { Mãe jovem de família numerosa. Muito } \\
\text { religiosa, sensível e recatada. É membro do Opus } \\
\text { Dei }\end{array}$ & 28 \\
\hline 2 & GUERREIRA & 43 & 4 & $\begin{array}{l}\text { Sofreu muito com doença da filha. Hoje mais } \\
\text { forte e otimista, se sente mais confiante e } \\
\text { próxima de Deus }\end{array}$ & \\
\hline 3 & DELICADA & 35 & 3 & $\begin{array}{l}\text { Profissional atuante. Dedicada à família e a } \\
\text { trabalhos sociais }\end{array}$ & 6 \\
\hline 4 & SERENA & 62 & 9 & $\begin{array}{l}\text { Dona de casa com família numerosa. Se dedica } \\
\text { a trabalhos voluntários. É membro do Opus } \\
\text { Dei. }\end{array}$ & 27 \\
\hline 5 & SINGELA & 45 & 6 & $\begin{array}{l}\text { Dona de casa, dedica exclusivamente à família. } \\
\text { É membro do Opus Dei }\end{array}$ & 13 \\
\hline 6 & ESFORÇADA & 58 & 2 & $\begin{array}{l}\text { Dona de casa, dedicada à família e a trabalhos } \\
\text { voluntários. É membro do Opus Dei. }\end{array}$ & 32 \\
\hline 7 & SENSIVEL & 40 & 3 & $\begin{array}{l}\text { Dona de casa em tempo integral. Se dedica a } \\
\text { trabalhos de catequese }\end{array}$ & 20 \\
\hline 8 & DEDICADA & 50 & 2 & $\begin{array}{l}\text { Trabalhou muitos anos em hospitais com } \\
\text { doentes terminais e suas famílias. Agora, } \\
\text { próxima da aposentadoria, começou a se dedicar } \\
\text { à atividades menos desgastantes }\end{array}$ & \\
\hline 9 & LÚCIDA & 48 & 0 & $\begin{array}{l}\text { Profissional atuante sem filhos. Hoje, se dedica } \\
\text { integralmente a dirigir uma escola. É membro } \\
\text { do Opus Dei }\end{array}$ & \\
\hline
\end{tabular}

Para a coleta de dados, optamos por utilizar a técnica da entrevista narrativa individual, semiestruturada, intercalando-se perguntas abertas e fechadas, conforme a necessidade da investigação. Organizadas a partir de um roteiro pré- estabelecido (Apêndice - Roteiro para as entrevistas), as perguntas foram respondidas oralmente e gravadas na íntegra, com o prévio consentimento do sujeito entrevistado (TCLE: Termo de Consentimento Livre e Esclarecido) ${ }^{47}$. Os dados foram colhidos individualmente em local e horário agendado por cada uma das entrevistadas, no período entre os meses de setembro/2010 e janeiro/2011.

Selecionamos esse tipo de entrevista por ser considerada uma técnica de pesquisa das mais ricas e flexíveis. E também, de acordo com Minayo (1994), por tratar-se de uma ferramenta importante - 
junto com a observação -, para a coleta de dados nas pesquisas de tipo qualitativa. Richardson (2010, p. 218), afirma que“cada entrevista em profundidade proporciona um riquíssimo material de análise". Composta a partir de duas palavras, entre e vista, que denotam uma situação relacional direta entre pessoas, o termo entrevista refere-se à percepção mútua, efetivada entre dois indivíduos. Ou, mais especificamente, diz respeito à percepção gerada de um foco entre dois pontos de vista diferentes.

As perguntas utilizadas nas entrevistas foram elaboradas a partir dos objetivos específicos da pesquisa:

- Verificar a frequência e a regularidade com que os sujeitos procuram esse tipo de orientação, a fim de determinar o seu nível de comprometimento no processo.

- Examinar como a D.E é percebida pela mulher atendida.

- $\quad$ Analisar como a D.E afeta (emoções, sentimentos e paixões) as mulheresque recebem essa orientação.

- Definir os principais fatores - motivação ${ }^{48}-$, que levam essas mulheres abuscarem a

D.E.

- Averiguar a influência efetiva da direção espiritual na estabilidadeemocionaldessas mulheres.

- Investigar como os sujeitos vivem as relações humanas - os relacionamentos familiar, social, profissional, etc.

- E sobretudo, como essa mulheres se relacionam com Deus.

Cada entrevista individual foi iniciada com a explanação do teor da pesquisa, procurando-se estimular uma conversa informal e descontraída. Posteriormente, foram esclarecidas as dúvidas específicas da entrevistada e alertando-se sobre a confidencialidade e total liberdade durante o processo. E, finalmente, foi solicitada a autorização para gravação em audio, juntamente com o consentimento por escrito (TCLE) acordado e assinado por todos os envolvidos, antes do início de cada

entrevista, seguindo-se rigorosamente as especificações do Comitê de Ética em Pesquisa - CEP/PUCPR.

\subsection{TÉCNICA DE ANÁLISE DO DISCURSO}

Em alguns trabalhos sobre a elaboração e a análise nos processos de pesquisa, o relatório tem merecido pouca atenção, ou é considerado uma atividade independente da análise dos dados. Hammersley; Atkinson (1983), insistem que o relatório faz parte inseparável do processo analítico, e que a sua estrutura pode influenciar o tipo de análise, ou, pelo menos, a compreensão do leitor. No 
mesmo sentido, de acordo com Richardson (2010), “a ausência de elementos importantes em um relatório, ou a sua má disposição, contrariando o bom-senso, a estética e as normas preestabelecidas, não raro comprometem, em sua extensão e qualidade, aquilo que se quer comunicar". Schrader, em seu livro Introdução á pesquisa social empírica, resume de maneira abrangente, o conteúdo do relatório de pesquisa da seguinte maneira:

O relatório começa com a formulação do problema; expõe dados da literatura existente sobre o tema e explicita a posição teórico- científica. Em seguida, apresenta uma lista completa das hipóteses; descreve os problemas da técnica de mensuração; fundamenta a escolha de um dos vários métodos; explica o procedimentomensurativo - a amostra e as técnicas de análise -; compara os dados com as hipóteses e formula - a partir das hipóteses explicativas confirmadas, refutadas ou reformuladas -, um ou mais enunciados teóricos com o quais se responde à pergunta inicial de investigação (SCHRADER, 1974, p.257).

Para o tratamento dos dados colhidos com as entrevistas, optamos pela análise do discurso, por tratar-se de uma técnica, de acordo com Minayo (1994, p. 71), "que tem a finalidade de apreender os significados dos textos, articulando-os àscondições remotas de sua produção". Assim, para essa mesma autora, é fundamental a identificação do contexto onde ele é produzido nos seus diferentes campos. É importante também, conferir se o discurso efetivamente se dá através da linguagem. Esta, segundo Marx e Engels (1984), expressa a consciência e a palavra é o símbolo da comunicação por excelência, uma vez que representa o pensamento. Assim, Bakhtin (1995) explica que a palavra é um fenômeno ideológico, é o modo mais puro e sensível da relação social. Deste modo, a fala revela condições estruturais, sistemas de valores, normas e símbolos, e tem a capacidade de transmitir as representações das pessoas, em condições históricas, sócio-econômicas e culturais específicas.

O processo da análise discursiva, de acordo com Caregnato (2006, p. 680), “tem a pretensão de interrogar os sentidos estabelecidos em diversas formas de produção, que podem ser verbais e não verbais, bastando que a sua materialidade produza sentido para interpretação; podem ser entrecruzadas com séries textuais (orais ou escritas) ou imagens (fotografias) ou linguagem corporal".

Lane (1985, p. 32), explica que "a linguagem é o ponto de partida para se compreender as representações dos sujeitos, uma vez que é através dela que as representações são construídas e comunicadas [...]. A linguagem oferece os signos e os símbolos que constroem as representações sobre a realidade, as quais permeiam todas as ações do sujeito, desde o pensar até o fazer”.

De acordo com Fiorin (1988), o discurso pressupõe dois campos, o da manipulação consciente, ou seja, a sintaxe discursiva, e o da determinação inconsciente, que se refere à semântica discursiva e que depende mais diretamente das formações sociais. 
Caregnato (2006, p. 680) lembra que "a análise de discurso trabalha com o sentido e não com o conteúdo do texto, um sentido que não é traduzido, mas produzido. Esta autora esclarece que o corpus da análise de discurso é constituída pela seguinte formulação: ideologia + história + linguagem. A ideologia é entendida como o posicionamento do sujeito quando se filia a um discurso, sendo o processo de constituição do imaginário que está no inconsciente, ou seja, os sistemas de ideias que constitui a representação; a história representa o contexto sócio histórico e a linguagem é a materialidade do texto gerando pistas do sentido que o sujeito pretende dar". Portanto, o discurso produzido pela fala sempre terá relação com o contexto sócio histórico de quem o produz.

Entendemos uma formação ideológica como a visão do mundo de uma dada classe social, e esta não existe desvinculada da linguagem. Assim, a cada formação ideológica corresponde uma formação discursiva, que é um conjunto de temas e figuras que materializa uma dada visão do mundo.

Fiorin (1988) lembra que se do ponto de vista genérico as formações ideológicas materializadas nas formações discursivas, é que determinam o discurso,do ponto de vista da análise, é o discurso que vai revelar quem é o sujeito inscritono discurso e qual é a sua visão de mundo.

O discurso então, segundo Fiorin $(1998$, p. 97) "é uma rede de combinações, o conjunto de frases que exprime o pensamento do sujeito, seu entendimento do mundo exterior, do mundo interior ou do agir sobre a realidade". Assim, a análise dediscurso não tem a intenção de verificar qual é a verdadeira posição ideológica do enunciador real mas, sim, as visões de mundo dos enunciadores inscritos no discurso. Portanto, a análise feita sob essa inspiração não pretende colocar em cheque a posição ideológica do enunciador real, mas sim, entender como o enunciador vê o mundo e, portanto, reconhecer, interpretar e reinterpretar as concepções sobre o determinado objeto.

É importante também ressaltar, conforme destaca Fiorin (1998, p. 99), o fato de que muitas são as possibilidades de interpretação dos depoimentos, mas estas devem estar sempre circunscritas no espaço do que foi dito e que "várias leiturasnão se fazem a partir do árbitro do leitor, mas de virtualidades presentes no texto".

É na estrutura do discurso que se revelam os temas subjacentes, ou seja, as concepções dos sujeitos. A estrutura narrativa comporta elementos concretos e elementos abstratos e o texto concretiza estes últimos através de temas. Já os elementos concretos são obtidos por meio de figuras.

De acordo com a explicação de Fiorin e Savioli:

Figuras são palavras ou expressões que correspondem a algo existente no mundo natural: substantivos concretos, verbos que indicam atividades físicas, adjetivos que expressão qualidades físicas; por sua vez, temas são palavras ou expressões que não correspondem a algo existente no mundo natural, mas a elementos que organizam, categorizam e ordenam a realidade percebida pelos sentidos (FIORIN; SAVIOLI, 1991, p. 137). 
Segundo esses autores, o nível temático e o figurativo são níveis sucessivos de concretização, deste modo, podemos ter textos temáticos, isto é, sem a cobertura figurativa, mas todo texto figurativo pressupõe, sob as figuras, um tema. Assim, para entender um texto figurativo é preciso alcançar seu nível temático.

\begin{abstract}
Para compreender o tema de um texto figurativo é preciso perceber primeiro as redes coerentes formadas pelas figuras. Num texto, o significado de uma figura está no seu encadeamento com outras figuras. É preciso ter bem presente que uma figura não tem significado em si mesma. Isoladamente, ela pode sugerir ideias muito variadas e noções muito imprecisas. Seu sentido nasce do encadeamento com outras figuras. Como se sabe, num texto, tudo é relação. O que dá sentido às figuras é um tema. Por isso, encontraro sentido de um conjunto de figuras encadeadas é achar o tema que está subjacente a elas (FIORIN; SAVIOLI, 1991, p. 139).
\end{abstract}

Os temas evidenciam os sentidos e os significados de cada ação contida no discurso. $\mathrm{Na}$ definição dos conteúdos dos discursos há um constante transitar entre a realidade e a teoria, num processo contínuo de interpretação sobre o que os dados significam, o que implicam e para onde levam.

A decomposição dos discursos dos sujeitos apresentada a seguir é resultado da técnica proposta por Fiorin (1989), que está fundamentada na teoria de Greimás ${ }^{49}$ ou teoria da Geração de Sentido do Texto, que permite a depreensão de frases temáticas.

É importante lembrar que a profundidade e a literalidade dos depoimentos dos sujeitos requer que várias leituras sejam feitas, buscando-se a apreensão dos temas subjacentes aos discursos.

Assim, após a transcrição literal das entrevistas, continuamos o processo de análise dos discursos, seguindo as recomendações sugeridas por Fiorin (1989), com atualização e adaptação de Car; Bertolozzi (1999):

A primeira etapa consiste na leitura repetida do texto, identificando os temas e as figuras (grifados no próprio texto - no nosso caso, em amarelo).

- $\quad$ Na segunda etapa, busca-se o encadeamento / articulação entre os temas e as figuras, identificando congruências e/ou ambiguidades na fala dos enunciadores.

- $\quad$ E finalmente, faz-se uma recomposição através de frases temáticas que sintetizam os temas e sub-temas do discurso em sua totalidade.

A decodificação dos discursos, segundo Fiorin (1989), sintetizada em frases temáticas, contém qualificativos que permitem o agrupamento dessas frases facilitando a classificação e categorização do material empírico. 
A seguir apresenta-se, passo a passo, as etapas dos procedimentos utilizados na análise dos discursos das mulheres entrevistadas, de acordo com as diretrizes de Car; Bertolozzi (1999, p. 348$355)$.

\subsubsection{Análise do discurso - Suj. TÍMIDA}

Identificação dos Temas e Figuras no discurso (ANEXO - Transcrição dasentrevistas gravadas):

Quadro 4-Temas e figuras - Suj. TÍMIDA

\begin{tabular}{|c|c|}
\hline TÍMIDA: Temas e Figuras com a D.E & Temas e Figuras antes da D.E \\
\hline Via o progresso do meu irmão & Via o mundo muito confuso e complexo \\
\hline Recebo uma boa formação espiritual & Me sentia sem direcionamento, sem rumo \\
\hline Ajuda dando maior segurança & Sem sentido pra vida, sem força \\
\hline Reafirma valores, acrescenta outros & Do meu interior me puxava - inquietação \\
\hline Ajuda a ver melhor a minha personalidade & Sem força - balançada \\
\hline Bate com minha forma de pensar & $\begin{array}{l}\text { Eu usava o que todo mundo usava - moda, } \\
\text { mas não me sentia bem }\end{array}$ \\
\hline Ajuda a aceitar as minhas limitações & Sempre fui tímida e reservada \\
\hline Ajuda a lutar contra timidez & Estava muito em “choque” \\
\hline Dá força. Ajuda com dificuldade e obstáculos & Me sentia tolhida, sem forças pra falar \\
\hline Desenvolvimento personalidade & Tendência natural: "reservadinha" \\
\hline $\begin{array}{l}\text { Ajuda nas decisões; no casamento, com os } \\
\text { filhos, nas dúvidas; a ver o caminho certo }\end{array}$ & Não tinha me lançado para agradar a Deus \\
\hline $\begin{array}{l}\text { Ajuda na paciência, na prudência, no saber o } \\
\text { momento certo }\end{array}$ & Psicólogo não "atinge" como diretor espiritual \\
\hline Ajuda a me lançar contra limitação: timidez & Pessoa inquieta, sem direcionamento \\
\hline $\begin{array}{ll}\text { Melhorou bastante relacionamento com } \\
\text { marido, Irmãos,amizades }\end{array}$ & Tinha problemas de relacionamento \\
\hline $\begin{array}{l}\text { Desenvolvimento como pessoa humana. Me } \\
\text { ajudou a fazer a vontade de Deus }\end{array}$ & Estava acomodada \\
\hline $\begin{array}{l}\text { Ajudou muito com os filhos, certeza do que } \\
\text { estava fazendo, exigindo }\end{array}$ & Estava desorientada \\
\hline Dá confiança na formação moral e espiritual & \\
\hline $\begin{array}{l}\text { Bate com convicções pessoais, tua vocação, } \\
\text { teu espírito, você inteira }\end{array}$ & \\
\hline Tenho fé; acredito no representante de Deus & \\
\hline $\begin{array}{|lccc|}\text { Dá segurança pela formação } & \text { moral } \\
\text { Formação humana, amor a Deus } & \\
\end{array}$ & \\
\hline $\begin{array}{l}\text { Direciona minhas energias pra saber o que } \\
\text { Deus quer de mim }\end{array}$ & \\
\hline $\begin{array}{l}\text { Esclarece as minhas dúvidas; me dá } \\
\text { fortaleza, paz, certeza e segurança de estarno } \\
\text { caminho certo }\end{array}$ & \\
\hline Faz falta, sinto falta. É como um alimento & Quando não consigo fazer, me sinto fraca \\
\hline
\end{tabular}




\subsubsection{Etapas da análise do discurso - Suj. Tímida:}

A primeira fase da análise do discurso foi feita com a recomposição atravésde frases temáticas $^{50}$, sintetizando os temas e sub-temas do discurso na sua totalidade. A segunda fase, com a reflexão, procedemos o encadeamento e articulação entre os temas e as figuras destacados (em amarelo no texto do anexo - TEGI), identificando congruências e/ou ambiguidades na fala dos enunciados.

Por fim, há uma leitura-síntese de cada depoimento feita a partir da abordagem fenomenológica “com o objetivo de alcançar o sentido da experiência, ou seja, o que a experiência significa para as pessoas que tiveram a experiência emquestão e que estão, portanto, aptas a dar uma descrição compreensiva desta" (HOLANDA, 2006, p. 371). Em cada depoimento, por conseguinte, concluise apartir da discussão de três pontos fundamentais: 1) sobre o significado da direção espiritual; 2) a imagem do diretor/a espiritual para o sujeito; 3) as vivências do nível ôntico e psicológico na sua relação.

As frases temáticas apuradas no discurso da Tímida, são as seguintes:

$1^{\text {a) }}$ Faço D.E há vinte e oito anos.2 $2^{\mathrm{a}}$ ) A D.E ajuda dando segurança. $3^{\mathrm{a}}$ ) Reafirmando valores.

$4^{\text {a }) ~ A c e i t a r ~ l i m i t a c ̧ o ̃ e s, ~ p r i n c i p a l m e n t e ~ a ~ t i m i d e z . ~}$

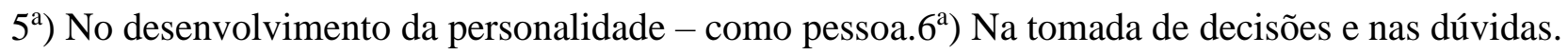

$7^{\mathrm{a})}$ Ver o caminho certo.

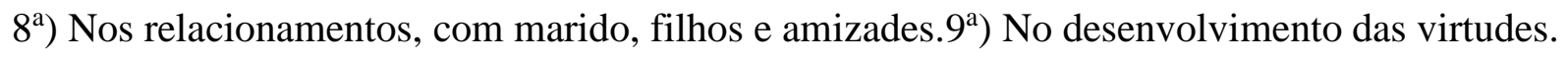

$10^{\mathrm{a}}$ ) Ajuda a conhecer e a fazer a vontade de Deus.

$11^{\mathrm{a}}$ ) É como um alimento espiritual. Dá segurança, confiança e paz.

A classificação / categorização das frases temáticas do discurso da Tímida, foi agrupada da seguinte maneira:

- As frases temáticas $2^{\mathrm{a}}, 3^{\mathrm{a}}, 10^{\mathrm{a}}$, referem-se à capacidade de ajuda efetiva da D.E,proporcionando confiança, segurança e paz ao Suj.

- As frases $7^{\mathrm{a}}, 10^{\mathrm{a}}$, referem-se à capacidade de ajuda da D.E, para aproximar a pessoa de Deus e a descobrir a sua vocação pessoal e o sentido da vida..

- As frases $2^{\mathrm{a}}, 3^{\mathrm{a}}, 10^{\mathrm{a}}$, referem-se à capacidade de ajuda da D.E no equilíbrio emocional do Suj.

- As frases $2^{\mathrm{a}}, 5^{\mathrm{a}}, 10^{\mathrm{a}}$, referem-se à habilidade da D.E, ajudando no discernimento, ponderação, maior facilidade e segurança com relação às tomadas de decisão.

- As frases $4^{\mathrm{a}}, 5^{\mathrm{a}}, 6^{\mathrm{a}}, 7^{\mathrm{a}} 8^{\mathrm{a}}$ e $9^{\mathrm{a}}$, referem-se à capacidade de ajuda da D.E, para o desenvolvimento das virtudes ${ }^{51}$, e ajudando a evitar os vícios, ou hábitos maus. 
- As frases $2^{\mathrm{a}}, 3^{\mathrm{a}}, 4^{\mathrm{a}}$, e $10^{\mathrm{a}}$, referem-se à capacidade de ajuda da D.E , no enfretamento das dificuldades e limitações pessoais.

- As frases $6^{\mathrm{a}}, 7^{\mathrm{a}}, 8^{\mathrm{a}}$ e $9^{\mathrm{a}}$, referem-se à capacidade de ajuda da D.E na administração de conflitos, especialmente nos relacionamentos conjugal e educação dos filhos, e nas relações sociais e profissionais.

- $\quad$ As frases $3^{\mathrm{a}}, 5^{\mathrm{a}}, 8^{\mathrm{a}}$ e $9^{\mathrm{a}}$ referem-se à capacidade de ajuda da D.E, fomentando o progresso e o amadurecimento interpessoal .

Com a conclusão da análise desse primeiro discurso, verificou-se que aTímida, a partir da D.E, passou a se sentir uma mulher mais madura. Para ela o acompanhamento espiritual é um fator chave para o desenvolvimento da própria personalidade. Segundo o seu depoimento, ela reconhece que a direção espiritual constitui uma "ajuda" na aceitação das próprias limitações, na superação da timidez, na administração dos conflitos no relacionamento familiar, na superação das dificuldades e obstáculos, e na realização da vontade de Deus. Deve-se notar que a Tímida definia a sua própria situação antes da D.E como: "sem direcionamento", "acomodada", "em choque", "reservada" e "sem forças para falar" e, ao mesmo tempo, indica ter buscado ajuda na psicoterapia, porém, salienta: "O psicólogo não atinge como o diretor espiritual", demarcando uma diferença.

A direção espiritual, psicologicamente falando, neste caso parece ser promotora do desenvolvimento humano, servindo inclusive à busca de autenticidadena vivência religiosa do sujeito. Pode-se, por outro lado, notar também os efeitos do trabalho da direção espiritual na vida da pessoa ao conferir-lhe maior confiança, força, capacidade de discernimento e favorecer maior segurança no caminho.

\subsubsection{Análise do discurso - Suj. GUERREIRA}

Identificação dos Temas e Figuras no discurso da Guerreira:

Quadro 5 - Temas e figuras - Suj. GUERREIRA

\begin{tabular}{|l|l|}
\hline GUERREIRA: Temas e Figuras com a D.E & Temas e Figuras antes da D.E \\
\hline Me faz falta quando não faço & Sem saber qual a necessidade da D.E \\
\hline $\begin{array}{l}\text { Comecei a enxergar a necessidade de um diretor } \\
\text { espiritual }\end{array}$ & \\
\hline É alguém que me leva, que me direciona & \\
\hline Na adolescência isso me ajudou muito & \\
\hline Que tipo de leitura, me aproxima de Deus & \\
\hline Conhecer sobre a Igreja Católica & \\
\hline $\begin{array}{l}\text { Ajuda a entender doença da filha; e ajudartambém a a } \\
\text { filha a entender o sentido da dor }\end{array}$ & Comeu a doença grave da filha aos 8anos \\
\hline $\begin{array}{l}\text { Esclarecer sobre filiação divina } \\
\text { Saber que Deus tinha um propósito para aquele } \\
\text { sofrimento }\end{array}$ & \\
\hline
\end{tabular}


Eu soube aproveitar o máximo! todo o sofrimento

Pessoas souberam aproveitar também aquele

sofrimento, pelas minhas atitudes; ninguém ficou

indiferente

Diretor espiritual foi muito importante pra mim, promeu

marido e filhos, e ajudou especialmente, a ela (filha) a

entender e aceitar a doença e todo o

sofrimento

Ajudou a entender como ela era forte, e importante pra Deus

Ela foi forte no sentido de ter confiança em Deus, então, ela não vacilava!

No início tinha o sentimento de revolta

Ela não tinha medo, ela não fraquejou.

Pensamos no amor de Deus, durante as grandes

dificuldades

Ajudou muito ao meu marido, dando fortaleza por

conta do relacionamento com Deus

Meu marido foi também o meu alicerce. Ajudou a

manter a paz e a superar barreiras

Hoje, minha filha é uma adolescente muito bem

resolvida, apesar das limitações

O Diretor (espiritual) é um especialista da alma, quando as coisas vão mal é que agente sabe com quem contar

O especialista diz a palavra certa, na hora certa .

E faz com que você vá pra frente

Sempre me ajudou mesmo, com as dúvidas, com os filhos

Mostrando o caminho que tínhamos que Estava desorientada

percorrer; sem isso eu não teria suportado!

$\mathrm{O}$ que ele me falou, me deu força pra suportar todo o resto.

Aceitação da vontade de Deus, não é fácil! Eu

aprendi a fazer. Considero um milagre

D.E me trouxe muito: consciência de que tudo é

para o meu bem: omnia in bonun!

Comove e influência as pessoas, que há anos

não iam à Missa e que passaram a ir por conta do

problema dela (minha filha)

Exemplo positivo de uma criança que apesar da

dor, estava sempre sorrindo. Porque ela aprendeu

a oferecer o sofrimento

Uniu muito mais a família; fortaleceu Muitos casais se separam por conta de

relacionamento marido e mulher (conjugal)

com a doença e com o sofrimento

O meu Diretor enxerga os meus problemas dum

foco especial. Ele é imparcial e tem experiência

espiritual

Ele me dizia mais o que eu não, devia fazer. Que

eu devia e podia, ser melhor

Faz com que eu procurasse alternativas

ajudava a fazer, ter paciência

Faz com que eu pense também o problema do

lado dos outro

A formação que o meu Diretor tem, me inspira

confiança

Confio que ele está procurando tirar o melhor de

mim. E que nunca é pro mal

filho doente

\begin{tabular}{|l|l|}
\hline e me & \\
\hline iae & $\begin{array}{l}\text { Muitas vezes eu tenho dúvidas em } \\
\text { relação ao que o Diretor me propõe }\end{array}$ \\
\hline de & \\
\hline
\end{tabular}


O bem que faz pra alma: o sentimento de

procurar ser melhor pra Deus e ter Deus comometa.

Vale a pena!

\subsubsection{Etapas da análise do discurso - Suj. Guerreira:}

A primeira fase da análise do discurso foi feita com a recomposição atravésde frases temáticas, sintetizando os temas e sub-temas do discurso na sua totalidade. A segunda fase, com a reflexão, procedemos o encadeamento e articulação entre os temas e as figuras grifados no texto, identificando congruências e/ou ambiguidades na fala dos enunciados.

As frases temáticas apuradas no discurso da Guerreira, são as seguintes: $1^{\text {a }}$ ) Faço D.E há vinte anos.

$\left.2^{a}\right)$ Me faz falta. É alguém que me leva, que me direciona.

$3^{\text {a) }}$ Me ajudou muito na adolescência (período de turbulência).

$4^{\mathrm{a}}$ ) A me aproximar de Deus, e a conhecer sobre a Igreja Católica. $5^{\mathrm{a}}$ ) Ajuda a entender doença da filha e entender o sentido da dor.

$6^{\mathrm{a}}$ ) Esclarecer sobre a filiação divina e a vontade de Deus. $7^{\mathrm{a}}$ ) Aproveitar ao maximo aquele sofrimento.

$8^{\text {a) }}$ Outras pessoas também souberam aproveitar aquele sofrimento.

9a) O diretor foi muito importante pra toda minha família, ajudando a entendere aceitar a doença e todo aquele sofrimento.

$10^{\mathrm{a}}$ ) Ajudou a entender como ela (doente) era forte e importante pra Deus .Hoje, é uma adolescente bem resolvida.

$11^{\mathrm{a})}$ Filha forte com a doença. não tinha medo. confiava em Deus.

$12^{\mathrm{a}}$ ) Ajudou muito o meu marido, dando fortaleza e confiança em Deus. 13 ${ }^{\mathrm{a}}$ ) Marido como alicerce, ajudando a manter a paz e superar as barreiras.

14 $4^{\mathrm{a}}$ O Diretor espiritual é um especialista da alma, com quem podemos contar, que fala palavra certa, na hora certa, que faz com que se vá pra frente, mostrando o caminho que devemos percorrer. Ele me ajuda a fazer o que tem que ser feito, a ter paciência. Faz com que eu pense também nos problemas dos outros. me inspira confiança e me dá segurança.

$15^{\text {a) }} \mathrm{O}$ que o Diretor falou me deu força para suportar tudo. Sem isso, eu não teria suportado. Eu considero um milagre.

$16^{\mathrm{a}}$ ) Aceitação da vontade de Deus, não é fácil! Eu aprendi a fazer. $17^{\mathrm{a}}$ ) Me trouxe a consciência de que tudo é para o bem.

$18^{a}$ ) Tenho minha filha como modelo positivo, que influência e comove as pessoas. Uma criança que, apesar da dor, estava sempre sorrindo (otimismo), porque aprendeu a oferecer o sofrimento. 
19ª) Uniu mais a nossa família e fortaleceu o meu relacionamento conjugal.20a ) Me ajudou a confiar e a ter Deus como meta.

A classificação / categorização das frases temáticas do discurso da Guerreira foi agrupada da seguinte maneira:

- $\quad$ As frases $4^{\mathrm{a}}, 5^{\mathrm{a}}, 6^{\mathrm{a}}, 10^{\mathrm{a}}, 11^{\mathrm{a}}, 12^{\mathrm{a}}, 15^{\mathrm{a}}, 16^{\mathrm{a}}, 17^{\mathrm{a}}$ e $20^{\mathrm{a}}$, referem-se à capacidade de ajuda da D.E, no sentido de aproximar a pessoa de Deus, a descobrir a suavocação pessoal e o sentido da vida.

- As frases $2^{\mathrm{a}}, 3^{\mathrm{a}}, 5^{\mathrm{a}}, 12^{\mathrm{a}}, 13^{\mathrm{a}}, 14^{\mathrm{a}}, 15^{\mathrm{a}}, 16^{\mathrm{a}}, 17^{\mathrm{a}}$ e $20^{\mathrm{a}}$, referem-se à capacidade de ajuda da D.E, proporcionando confiança, segurança e paz.

- As frases $5^{\mathrm{a}}, 9^{\mathrm{a}}, 11^{\mathrm{a}}, 13^{\mathrm{a}}, 15^{\mathrm{a}}, 17^{\mathrm{a}}$ e3 $19^{\mathrm{a}}$, referem-se à capacidade de ajuda da

D.E no equilíbrio emocional.

- As frases $11^{\mathrm{a}}$ e $14^{\mathrm{a}}$, referem-se à habilidade da D.E ajudando no discernimento,ponderação e maior segurança com relação às tomadas de decisão.

- $\quad$ As frases, $3^{\mathrm{a}}, 7^{\mathrm{a}}, 11^{\mathrm{a}}, 12^{\mathrm{a}}, 14^{\mathrm{a}}, 16^{\mathrm{a}}, 17^{\mathrm{a}}$ e $19^{\mathrm{a}}$, referem-se à capacidade de ajudada D.E para $\mathrm{o}$ desenvolvimento das virtudes e evitar os vícios.

- As frases $5^{\mathrm{a}}, 7^{\mathrm{a}}, 9^{\mathrm{a}}, 10^{\mathrm{a}}, 11^{\mathrm{a}}, 14^{\mathrm{a}}$ e $15^{\mathrm{a}}$, referem-se à capacidade de ajuda da D.Eno enfretamento das dificuldades e limitações pessoais.

- As frases $3^{\mathrm{a}}, 14^{\mathrm{a}}$ e $19^{\mathrm{a}}$, referem-se à capacidade de ajuda da D.E naadministração de conflitos, especialmente nos relacionamentos conjugal e educação dos filhos, e nas relações sociais e profissionais.

- As frases $5^{\mathrm{a}}, 10^{\mathrm{a}}, 11^{\mathrm{a}}, \quad$ e $18^{\mathrm{a}}$, referem-se à capacidade de ajuda da D.E no fortalecimento da auto-estima e auto-determinação do sujeito.

- As frases $5^{\mathrm{a}}, 6^{\mathrm{a}}, 9^{\mathrm{a}}, 11^{\mathrm{a}}, 14^{\mathrm{a}}, 16^{\mathrm{a}}, 17^{\mathrm{a}}, 18^{\mathrm{a}}, 19^{\mathrm{a}}$ e $20^{\mathrm{a}}$, referem-se à influênciapositiva da D.E, fomentando o amadurecimento interpessoal do sujeito.

Concluindo-se a análise desse discurso, verifica-se em primeiro lugar, que para a Guerreira, a direção espiritual tem um significado muito profundo porque tem marcado o desenvolvimento da sua personalidade em diferentes etapas: na adolescência - período denominado por ela como de 'turbulências' -; na juventude e idade adulta, principalmente, apoiando a vida conjugal e o enfrentamento da doençada filha. Já com relação à imagem do diretor espiritual - definida por ela como "umespecialista da alma", emerge dados significativos quanto aos requisitos necessários para exercer a direção espiritual com responsabilidade e competência. O primeiro deles, conforme o depoimento, é a "experiência espiritual", isto é, a qualidade religiosa do diretor sendo capaz de enxergar os problemas e apresentar um modo de enfrentá-los a partir da experiência de fé. O segundo requisito destacado pela Guerreira é quanto à preparação específica e adequada do diretor que inspira a atitude de confiança por parte do dirigido, ela diz: "a formação que o meu Diretor tem que me inspira 
confiança" e, além disso, continua: "o especialistadiz a palavra certa e na hora certa, faz com que você vá pra frente". Um terceiro requisito do diretor, sublinhado no depoimento, é a imparcialidade, ou seja, capacidade de propor alternativas aos problemas e levar a dirigida a enxergar os problemas não apenas na própria perspectiva mas na perspectiva do outro.

As orientações com o diretor espiritual ajudaram-na a encontrar equilíbrio emocional, a fortalecer o relacionamento familiar e, além disso, foi decisivo na formade conduzir e encaminhar a filha portadora de uma enfermidade crônica grave. Paraa Guerreira a prática da direção espiritual serviu para mostrar o caminho a ser percorrido quando se sofre e se tem de enfrentar a doença na família. Segundo seu depoimento, a direção espiritual fez compreender o sentido da dor e do sofrimento tanto para ela, como para o marido e a filha. Por isso, ela foi capaz de dizer que sem a direção espiritual , muito provavelmente, ela "não teria suportado!".

\subsubsection{Análise do discurso - Suj. DELICADA}

Identificação dos Temas e Figuras no discurso da Delicada:

Quadro 6-Temas e figuras - Suj. DELICADA

\begin{tabular}{|l|l|}
\hline DELICADA: Temas e Figuras com a D.E & Temas e Figuras antes da D.E \\
\hline $\begin{array}{l}\text { Ajuda a ver em que etapa estou na minha vida } \\
\text { espiritual, aonde quero ir, aonde Deus me chama ,me } \\
\text { conduzir na verdade }\end{array}$ & Estava desorientada \\
\hline Ajuda a manter o crescimento espiritual & \\
\hline Ajuda na caminhada mais concreta e efetiva & Estava “solta” \\
\hline Tenho um guia, alguém que me dá um norte & \\
\hline Vejo o caminho mais traçado e delimitado fazer \\
\hline Ajuda a confiar em Deus e te aproxima Dele & Estava desanimada \\
\hline Ter fé e não desanimar frente obstáculos & \\
\hline $\begin{array}{l}\text { Dá confiança, fortaleza, paciência com os outros } \\
\text { Pessoa mais madura, com os filhos, no trabalho, } \\
\text { relacionamento conjugal, aproveitando o tempo }\end{array}$ & \\
\hline $\begin{array}{l}\text { Ajuda com as dificuldades, traduz, dá dicas, } \\
\text { orientação, suporte, puxão de orelha }\end{array}$ & \\
\hline É como uma mão que estende e ajuda a caminhar & \\
\hline $\begin{array}{l}\text { Ajuda a entender o que Deus quer de mim } \\
\text { Fornece estratégias, recursos e dicas. É como quando se } \\
\text { está doente e você procura um médico. Para ajudar na } \\
\text { espiritualidade, tem-se que se } \\
\text { procurar um sacerdote }\end{array}$ & \\
\hline
\end{tabular}




\subsubsection{Etapas da análise do discurso - Suj. Delicada}

A primeira fase da análise do discurso foi feita com a recomposição atravésde frases temáticas, sintetizando os temas e sub-temas do discurso na sua totalidade. A segunda fase, com a reflexão, procedemos o encadeamento e articulação entre os temas e as figuras, identificando congruências e/ou ambiguidades na fala dos enunciados.

As frases temáticas apuradas no discurso da Delicada, são as seguintes: $1^{\text {a) }}$ Faço D.E há cinco, quase seis anos.

$2^{\text {a }) ~ A ~ D . E ~ a j u d a ~ n a ~ e s p i r i t u a l i d a d e, ~ c o m o ~ u m ~ m e d i c o ~ c o m ~ o ~ c o r p o . ~} 3^{\mathrm{a}}$ ) Mantendo o crescimento espiritual.

$4^{\text {a) }}$ Como guia que ajuda na caminhada mais efetiva e concreta.

$5^{\text {a) }}$ Como alguém que acompanha num caminho bem traçado e delimitado; $6^{\mathrm{a}}$ ) Ajuda a se aproximar e confiar em Deus.

$7^{\mathrm{a}}$ ) A não desanimar frente aos obstáculos. $8^{\mathrm{a}}$ ) Dá certeza da presença de Deus.

$\left.9^{a}\right)$ Dá confiança, fortaleza e paciência com os outros. $10^{a}$ ) Se torna mais acessível e mais atenciosa.

$\left.11^{\mathrm{a}}\right)$ Mais madura, com os filhos, no trabalho e no relacionamento conjugal;12a) Aproveitando bem o tempo.

13 $3^{a}$ Ajuda nas dificuldades - traduz, dá dicas, orientação, suporte e puxãode orelha quando necessário.

$14^{\mathrm{a}}$ ) Sendo caminho, mão que estende e ajuda a caminhar.15 ) O diretor é como um instrumento de Deus.

$16^{\mathrm{a}}$ ) Fornece estratégias, recursos e dicas para problemas espirituais.17 ${ }^{\mathrm{a}}$ ) Ajuda a entender o que Deus quer de mim.

$18^{\mathrm{a}}$ ) Recomenda com certeza, ajuda a melhorar como pessoa.

$19^{a}$ ) Ajuda no relacionamento com o esposo numa dimensão sobrenatural - ponho tudo nas mãos de Deus.

$20^{\mathrm{a}}$ ) Ajuda a conhecer o plano que Deus tem para mim.

Classificação ; categorização das frases temáticas do sujeito:

- As frases $2^{\mathrm{a}}, 3^{\mathrm{a}}, 4^{\mathrm{a}}, 5^{\mathrm{a}}, 6^{\mathrm{a}}, 8^{\mathrm{a}}, 14^{\mathrm{a}}, 17^{\mathrm{a}}$ e $20^{\mathrm{a}}$ referem-se à capacidade de ajuda da D.E, no sentido de aproximar a pessoa de Deus e a descobrir a sua vocação pessoal e o sentido da vida.

- As frases $4^{\mathrm{a}}, 8^{\mathrm{a}}$ e $15^{\mathrm{a}}$, referem-se à capacidade de ajuda da D.E, proporcionando confiança, segurança e paz.

- As frases $2^{\mathrm{a}}, 3^{\mathrm{a}}$ e $12^{\mathrm{a}}$, referem-se à capacidade de ajuda da D.E no equilíbrio emocional do Suj.

- As frases $4^{\mathrm{a}}, 11^{\mathrm{a}}, 12^{\mathrm{a}}, 13^{\mathrm{a}}, 16^{\mathrm{a}}, 18^{\mathrm{a}}$ e $19^{\mathrm{a}}$, referem-se à habilidade da D.E, ajudando no 
discernimento, ponderação, maior facilidade e segurança com relação às tomadas de decisão na vida do Suj.

- As frases $3^{\mathrm{a}}, 9^{\mathrm{a}}, 11^{\mathrm{a}}, 12^{\mathrm{a}}, 13^{\mathrm{a}}$ e $18^{\mathrm{a}}$, referem-se à capacidade de ajuda da D.E, para o desenvolvimento das virtudes.

- As frases $7^{\mathrm{a}}, 9^{\mathrm{a}}, 11^{\mathrm{a}}, 13^{\mathrm{a}}$ e $16^{\mathrm{a}}$, referem-se à capacidade de ajuda da D.E , no enfretamento das dificuldades e limitações pessoais.

- As frases $9^{\mathrm{a}}, 10^{\mathrm{a}}, 11^{\mathrm{a}}$ e $19^{\mathrm{a}}$, referem-se à capacidade de ajuda da D.E naadministração de conflitos, especialmente nos relacionamentos conjugal e educação dos filhos, e nas relações sociais e profissionais. Fomentando o progresso e o amadurecimento interpessoal.

A partir da análise desse discurso, verifica-se que a Delicada, desde começou a sua direção espiritual, declara ter encontrado uma ajuda decisiva que permite compreender o quanto esta experiência foi determinante para o seu crescimento pessoal. Para ela a direção espiritual representa uma "ajuda” em diversos níveis: “ajuda a ver a etapa em que está na vida espiritual [...] ajuda nas dificuldades [...] ajuda na confiança e abertura a Deus [...] ajuda na caminhada mais concreta e efetiva [...] ajuda a entender o que Deus quer de mim”. Porém, é preciso notar que antes da prática da direção espiritual ela sentia-se desorientada, "solta" e "desanimada". O que parece importante aqui é compreender como estes dois momentos do tempo, isto é, o antes e o depois da direção espiritual, são explicitados no depoimento da Delicada. Tal análise permite supor que essa experiência tenha uma importância ainda maior do que aquela considerada aqui e explicitada em seu depoimento.

O diretor espiritual vem definido pela Delicada como "instrumento de Deus", "uma mão estendida para ajudar no caminho" e, sobretudo, no discernimento da vontade de Deus no cotidiano; ele tem a tarefa de fortalecer a espiritualidade. Além disso, define-o como guia, alguém que propõe um norte para a vida com dicas, orientação, estratégias e suporte.

\subsubsection{Análise do discurso - Suj. SERENA}

Identificação dos Temas e Figuras no discurso do sujeito:

Quadro 7 - Temas e figuras - Suj. SERENA

\begin{tabular}{|l|l|}
\hline SERENA: Temas e Figuras com a D.E & Temas e Figuras, antes da D.E \\
\hline Percebi que isso era muito importante pra mim & \\
\hline $\begin{array}{l}\text { A D.E me dá tudo!: segurança, me sinto forte, } \\
\text { compreendida e amparada }\end{array}$ & \\
\hline $\begin{array}{l}\text { Sentia firmeza ; mais claro o que estava certo e o que não ; } \\
\text { tinha segurança e consolo ; Sabia que estava no caminhoci numa época de confusão, ficava } \\
\text { seguro pra ir pra Deus ; Vi muito } \\
\text { claro a minha vocação }\end{array}$ & $\begin{array}{l}\text { meio perdida ; Insegura ; sem uma direção } \\
\text { Ajuda a adquirir virtudes }\end{array}$ \\
\hline
\end{tabular}


Tenho a sorte de ter um bom pastor, uma pessoa devida|Estava desorientada

íntegra, que segue as diretrizes da Igreja; fala muito claro,

e seus conselhos vão me levando por

um caminho seguro

Ajuda no meu plano de vida, com os problemas de

relacionamento com o marido, com o

relacionamento familiar de um modo geral

\begin{tabular}{|l|l|}
\hline Aprendi a aceitar as pessoas como são, com amor, & Tinha dificuldade de relacionamento
\end{tabular}

paciência, humildade e as virtudes em geral

É uma luz, pra eu saber como devo agir

Hoje eu faço D.E com uma mulher, as vezes é mais

fácil pra conversar ; Não faz diferença, é como sefosse

Jesus ali falando

\begin{tabular}{|l|l}
\hline Ajuda a descobrir uma maneira material de tornar o & Dificuldades com o plano de vida
\end{tabular}

plano de vida possível

As vezes ela só me escuta, porque quando eu falo, já vem a luz

A minha diretora tem a Graça de Deus; ela espera

que eu cresça em virtudes e em amor a Deus; e queeu

alcance a santificação

Se lucra muito com a D.E; te aproxima de Deus.

Abre a cabeça e o coração pras coisas de Deus

Dá segurança de estar no caminho certo e de saber

que tudo contribui para o bem!

\subsubsection{Etapas da análise do discurso - Suj. Serena}

A primeira fase da análise do discurso foi feita com a recomposição atravésde frases temáticas, sintetizando os temas e sub-temas do discurso na sua totalidade. A segunda fase, com a reflexão, procedemos o encadeamento e articulação entre os temas e as figuras, identificando congruências e/ou ambiguidades na fala dos enunciados.

As frases temáticas apuradas no discurso da Serena, são as seguintes: $1^{\text {a }}$ ) É muito importante pra mim. Me dá tudo;

$\left.2^{a}\right)$ Dá segurança, me sinto compreendida, amparada, escutada e ajudadacom os conflitos. Sentia firmeza e consolo. Mais claro o certo e o errado;

$3^{\text {a) }}$ Sabia que estava no caminho seguro. Vi clara a minha vocação. $4^{\mathrm{a}}$ ) Ajuda a adquirir virtudes amor, paciência e humildade;

$5^{a}$ ) Tenho sorte de ter um pastor confiável - uma pessoa íntegra que fala claro e me encaminha pro caminho seguro e saber como agir. É como se fosse Jesus falando pra mim. Tem uma graça especial para orientar;

$6^{\text {a) }}$ Me dá luz. Me ajuda no plano de vida. Mostra como tornar meu objetivo possível, como realizar (tornar real);

$7^{\mathrm{a}}$ ) Ajuda a melhorar os relacionamentos, e a aceitar as pessoas como são. 
$8^{\text {a }) ~ H o j e, ~ e u ~ a c r e d i t o ~ e ~ c o n f i o ~ q u e ~ t u d o ~ n a ~ v i d a ~ c o n v e r g e ~ p a r a ~ o ~ b e m . ~}$

Classificação ; categorização das Frases Temáticas do sujeito:

- As frases $1^{\mathrm{a}}, 2^{\mathrm{a}}, 3^{\mathrm{a}}, 5^{\mathrm{a}}, 6^{\mathrm{a}}$ e $8^{\mathrm{a}}$ referem-se à capacidade de ajuda da D.E, no sentido de aproximar a pessoa de Deus e a descobrir a sua vocação pessoal e o sentido da vida.

- As frases $1^{\mathrm{a}}, 2^{\mathrm{a}}, 3^{\mathrm{a}}, 5^{\mathrm{a}}$ e $8^{\mathrm{a}}$ referem-se à capacidade de ajuda da D.E, proporcionando confiança, segurança e paz.

- As frases $1^{\mathrm{a}}, 2^{\mathrm{a}}, 4^{\mathrm{a}}$ e $6^{\mathrm{a}}$ referem-se à capacidade de ajuda da D.E para o equilíbrio emocional do Suj.

- $\quad$ As frases $2^{\mathrm{a}}, 4^{\mathrm{a}}, 6^{\mathrm{a}}$ e $7^{\mathrm{a}}$ referem-se à habilidade da D.E, ajudando no discernimento, ponderação, maior facilidade com relação às tomadas de decisão.

- $\quad$ As frases $2^{\mathrm{a}}, 3^{\mathrm{a}}$ e $4^{\mathrm{a}}$ referem-se à capacidade de ajuda da D.E, para o desenvolvimento das virtudes.

- As frases $4^{\mathrm{a}}, 6^{\mathrm{a}}$ e $7^{\mathrm{a}}$ referem-se à capacidade de ajuda da D.E, na administração de conflitos, nos relacionamentos, principalmente, conjugal e educação dos filhos. Fomentando o progresso e o amadurecimento interpessoal.

É fundamental considerar em primeiro lugar, o significado da direção espiritual no depoimento. A definição dada é de que a direção espiritual é uma luz. Curioso notar, por outro lado, que este significado da direção está ligado a uma concepção relacional do acompanhamento realizado quando afirma, por exemplo, que a diretora "às vezes só escuta, porque quando eu falo, já vem a luz". Ela mostra, desse modo, que a direção espiritual - tal como está sendo realizada - não acentua simplesmente o aspecto diretivo e de conteúdos, mas a interação. Pode-se dizer que fica sugerida a relação entre o nível espiritual e psicológico do ser humanoe a necessidade de compartilhar com outro as experiências e vivências destes níveis. O contato aqui é com uma diretora espiritual, diferente dos outros relatos nosquais aparece a figura de um diretor que, na maior parte das vezes, é um sacerdote. No depoimento aparece o significado da direção como algo "muito importante" a nível pessoal a fim de ajudar no "plano da vida", por conseguinte, no relacionamentointerpessoal.

\subsubsection{Análise do discurso - Suj. SINGELA}

Identificação dos Temas e Figuras no discurso do sujeito: 
Quadro 8-Temas e figuras - Suj. SINGELA

\begin{tabular}{|l|l|}
\hline SINGELA: Temas e Figuras com a D.E & Temas e Figuras antes da D.E \\
\hline $\begin{array}{l}\text { Me aproxima mais da Igreja. Me ajuda bastante. É } \\
\text { uma rotina boa na minha vida }\end{array}$ & Estava sem um direcionamento \\
\hline $\begin{array}{l}\text { Ajuda a compreender melhor o trabalho, a família } \\
\text { e na convivência em geral }\end{array}$ & Vontade de conversar com o padre \\
\hline $\begin{array}{l}\text { Pensar mais profundamente, de uma maneira } \\
\text { mais cristã e transcendente }\end{array}$ & \\
\hline $\begin{array}{l}\text { Me acalma e tranquiliza. Me aconselha, nasdúvidas } \\
\text { de fé, Mandamentos, Doutrina e coisas } \\
\text { sobrenaturais }\end{array}$ & Me sentia desorientada e insegura \\
\hline $\begin{array}{l}\text { Ajuda na paciência, a doar-se, na fortaleza, naordem, } \\
\text { saber calar. Nos relacionamentos e } \\
\text { convivência em geral }\end{array}$ & Tinha dificuldade de relacionamento \\
\hline $\begin{array}{l}\text { Dá equilíbrio e me aproxima mais de Deus } \\
\text { Como uma faxina, uma higienização. Me faz bem,me } \\
\text { deixa mais leve, mais limpa, como depois do } \\
\text { banho }\end{array}$ & \\
\hline $\begin{array}{l}\text { Sempre procurando melhorar, nós vamos } \\
\text { resolvendo os pequenos problemas sem deixar } \\
\text { que fiquem grandes }\end{array}$ & Estava acomodada \\
\hline $\begin{array}{l}\text { Vale a pena! pra acalmar e, principalmente, } \\
\text { aproximar mais de Deus }\end{array}$ & \\
\hline
\end{tabular}

\subsubsection{Etapas da análise do discurso - Suj. Singela}

A primeira fase da análise do discurso foi feita com a recomposição através de frases temáticas, sintetizando os temas e sub-temas do discurso na sua totalidade. A segunda fase, com a reflexão, procedemos o encadeamento e articulação entre os temas e as figuras, identificando congruências e/ou ambiguidades na fala dos enunciados.

As frases temáticas apuradas no discurso da Singela, são as seguintes: $1^{\text {a }}$ ) Faço D.E há treze anos.

$\left.2^{\mathrm{a}}\right)$ Me ajuda bastante. É uma rotina boa na minha vida.

$3^{\mathrm{a}}$ ) Ajuda compreender melhor o trabalho, família e na convivência em geral. $4^{\mathrm{a}}$ ) Pensar mais profundamente, de uma maneira mais transcendente.

$5^{\text {a) }}$ Me acalma e tranquiliza. Me aconselha da maneira correta. Vai direto aoponto. Nas dúvidas de fé, Mandamentos, Doutrina e coisas sobrenaturais.

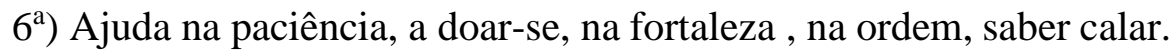

$7^{\mathrm{a})}$ Dá equilíbrio e me aproxima mais de Deus.

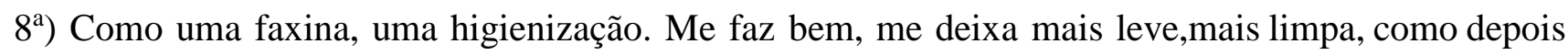
do banho.

$9^{\text {a }) ~ A j u d a ~ a ~ m e l h o r a r: ~ a ~ r e s o l v e r ~ o s ~ p e q u e n o s ~ p r o b l e m a s ~ s e m ~ d e i x a r ~ q u e ~ s e t o r n e m ~ g r a n d e s . ~}$

Classificação ; categorização das Frases Temáticas do sujeito:

- As frases $4^{\mathrm{a}}, 5^{\mathrm{a}}$ e $7^{\mathrm{a}}$ referem-se à capacidade de ajuda da D.E, para aproximar a pessoa de Deus e a descobrir a sua vocação pessoal e o sentido da vida. 
- As frases $2^{\mathrm{a}}, 3^{\mathrm{a}}, 4^{\mathrm{a}}, 5^{\mathrm{a}}, 7^{\mathrm{a}}, 8^{\mathrm{a}}$ e $9^{\mathrm{a}}$ referem-se à capacidade de ajuda da D.E, proporcionando confiança, segurança e paz.

- As frases $2^{\mathrm{a}}, 4^{\mathrm{a}}, 5^{\mathrm{a}}$ e $7^{\mathrm{a}}$ referem-se à capacidade de ajuda da D.E no equilíbrio emocional do Suj.

- As frases $3^{\mathrm{a}}, 4^{\mathrm{a}}, 5^{\mathrm{a}}, 6^{\mathrm{a}}$ e $9^{\mathrm{a}}$ referem-se à habilidade da D.E, ajudando no discernimento, ponderação, maior facilidade e segurança com relação às tomadas de decisão na vida do Suj.

- As frases $2^{\mathrm{a}}, 6^{\mathrm{a}}, 8^{\mathrm{a}}$ e $9^{\mathrm{a}}$ referem-se à capacidade de ajuda da D.E, para o desenvolvimento das virtudes.

- As frases $3^{\mathrm{a}}, 6^{\mathrm{a}}$ e $9^{\mathrm{a}}$ referem-se à capacidade de ajuda da D.E, na administração de conflitos, nos relacionamentos, principalmente conjugal e educação dos filhos. Fomentando o progresso e o amadurecimento interpessoal do sujeito.

Com a conclusão da análise do discurso da Singela, verifica-se que, hoje, essa mulher se considera, de uma maneira geral, uma pessoa com maior segurança no processo de tomada de decisão, mais calma, serena e próxima de Deus. Utiliza imagens para falar da direção espiritual e declara: "é como uma faxina", "uma higienização", "um banho", comparações que mostram a sinceridade por parte de quem está sendo dirigida de reconhecer a própria pobreza, de descobrir os pecados e sentir a necessidade da conversão como estímulo para progredir nos caminhos do Espírito. Pode-se discriminar que ela com a D.E faz experiência tanto no nível psicológico, pois se sente "calma", "tranquila", "leve"; bem como apresenta experiências ônticas referentes a sua vivência espiritual e religiosa quando diz, por exemplo, que a direção espiritual he faz "pensar mais profundamente, de maneira mais cristã e transcendente", aproximando-a de Deus.

\subsubsection{Análise do discurso - Suj. ESFORÇADA}

Identificação dos Temas e Figuras no discurso do sujeito:

Quadro 9- Temas e figuras - Suj. ESFORÇADA

\begin{tabular}{|l|lc|}
\hline ESFORÇADA: Temas e Figuras com a D.E & Temas e Figuras antes da D.E \\
\hline $\begin{array}{l}\text { A direção, começou a preencher o vazio. Me ajudou } \\
\text { muito. Vou continuar pra sempre }\end{array}$ & $\begin{array}{l}\text { Sentia uma necessidade interior que } \\
\text { não sabia o que era... parecia vazia }\end{array}$ \\
\hline As dificuldades passaram a ter um sentido diferente & $\begin{array}{l}\text { Dificuldades eram pesadas, } \\
\text { carregava de arrasto, tudo era difícil }\end{array}$ \\
\hline Melhor pra todo mundo. Significa uma ajuda & Foi difícil o acidente com meu pai \\
\hline $\begin{array}{l}\text { Eu tendo a direção, passei a ajudar minha família a } \\
\text { entender melhor o problema dele }\end{array}$ & $\begin{array}{l}\text { Pai nervoso, dificuldade no } \\
\text { relacionamento com ele }\end{array}$ \\
\hline $\begin{array}{l}\text { O diretor me dá o conselho. Ele orienta e eu faço ou } \\
\text { não faço }\end{array}$ & $\begin{array}{l}\text { As coisas do mundo não me } \\
\text { satisfaziam }\end{array}$ \\
\hline O diretor espiritual vê as coisas de fora & Me sentia desorientada e perdida \\
\hline O diretor tem uma maior presença de Deus & \\
\hline Eu me identifiquei com a D.E & \\
\hline
\end{tabular}


A orientação que vai esclarecer, dar umas dicas. Eu

faço ou não

Ajuda nos problemas com filhos adolescentes

Eu passei a ter uma serie de virtudes que antes eu não tinha:Mãe de idade, que mora comigo, eu

mais fortaleza, mais paciência com as pessoas. Aacabava perdendo a paciência

sinceridade, a humildade, e uma serie

de virtudes que fui adquirindo em função da direção

É uma forma de melhorar em todos os sentidos.

Sendo uma pessoa melhor

Sabendo ajudar mais os outros

Talvez, um bom diretor espiritual, ajudasse muito

mais do que um psicólogo

Acho que isso é que esta faltando hoje

O Diretor pode ser um sacerdote ou uma pessoa leiga desdeEu não queria sair me abrindo pra

que tenha formação pra isso. Viver as virtudes e ter atitudesqualquer pessoa

corretas.

Especialmente, ter a graça de Deus

\subsubsection{Etapas da análise do discurso - Suj. Esforçada}

A primeira fase da análise do discurso foi feita com a recomposição através de frases temáticas, sintetizando os temas e sub-temas do discurso na sua totalidade. A segunda fase, com a reflexão, procedemos o encadeamento e articulação entre os temas e as figuras, identificando congruências e/ou ambiguidades na fala dos enunciados.

As frases temáticas apuradas no discurso da Esforçada, são as seguintes: $1^{\text {a }}$ ) Faço D.E à trinta e dois anos.

$\left.2^{\mathrm{a}}\right)$ Me ajudou muito. Começou a preencher um vazio.

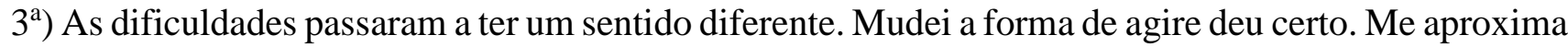
de Deus.

$4^{\text {a }) ~ P a s s e i ~ a ~ a j u d a r ~ a ~ m i n h a ~ f a m i ́ l i a ~ a ~ e n t e n d e r ~ m e l h o r ~ o ~ s o f r i m e n t o . ~}$

$\left.5^{\mathrm{a}}\right) \mathrm{O}$ diretor espiritual vê as coisas de fora: ele dá dicas, eu faço ou não. $6^{\mathrm{a}}$ ) Ajuda nos problemas com os filhos. Sabendo ajudar mais os outros.

$7^{\mathrm{a}}$ ) Adquiri uma serie de virtudes. Exemplo: a fortaleza, paciência com aspessoas, a sinceridade, a humildade.

Classificação ; categorização das Frases Temáticas do sujeito:

- As frases $2^{\mathrm{a}}$ e $3^{\mathrm{a}} \quad$ referem-se à capacidade de ajuda da D.E, no sentido deaproximar a pessoa de Deus e a descobrir o sentido da vida.

- As frases $2^{\mathrm{a}}, 3^{\mathrm{a}}, 4^{\mathrm{a}}, 5^{\mathrm{a}}$ e $6^{\mathrm{a}}$ referem-se à capacidade de ajuda da D.E,proporcionando confiança, segurança e paz.

- As frases $2^{\mathrm{a}}, 3^{\mathrm{a}}$ e $7^{\mathrm{a}}$ referem-se à capacidade de ajuda da D.E no equilíbrioemocional do Suj.

- As frases $3^{\mathrm{a}}, 4^{\mathrm{a}}, 5^{\mathrm{a}}, 6^{\mathrm{a}}$ e $7^{\mathrm{a}}$ referem-se à habilidade da D.E, ajudando no discernimento, ponderação, 
maior facilidade e segurança com relação às tomadas de decisão na vida do Suj.

- As frases $6^{\mathrm{a}}$ e $7^{\mathrm{a}}$ referem-se à capacidade de ajuda da D.E, no o desenvolvimento das virtudes.

- As frases $4^{\mathrm{a}}, 5^{\mathrm{a}}, 6^{\mathrm{a}}$ e $7^{\mathrm{a}}$ referem-se à capacidade de ajuda da D.E, na administração de conflitos, nos relacionamentos, principalmente o conjugal e educação dos filhos. Fomentando o amadurecimento interpessoal do sujeito.

Pode-se dizer que a Esforçada reconhece na direção espiritual uma relação nascida a partir de um pedido de ajuda: pois esta relação começou a preencher o vazio e fazer com que todas as coisas pudessem ter um sentido. A forma de considerar o diretor espiritual vem caracterizada como "alguém que vê as coisas de fora”; “orienta e dá conselhos”, isto é, ela aponta para uma das funções clássicas dodiretor/a que é a de iluminar e discernir tendo em conta tanto os fatores externosque exercem influência sobre o indivíduo como também os condicionamentos internos. Nesse depoimento pode-se identificar também - dada a liberdade em procurar esta ajuda de forma permanente por parte do sujeito -, a aquisição de atitudes (virtudes) consideradas fundamentais para os que desejam progredir no caminho do Senhor e que são classificadas como as atitudes do próprio dirigido. A Esforçada diz que a direção espiritual lhe trouxe maior: "fortaleza, paciência com as pessoas, a sinceridade, a humildade, e uma série de virtudes que a gente vai adquirindo em função da direção". Além disso, ela compreende que a direção tem o significado de ajuda e não está determinada a anular a própria liberdade.

\subsubsection{Análise do discurso - Suj. SENSÍVEL}

Identificação dos Temas e Figuras no discurso do sujeito:

Quadro 10 - Temas e figuras - Suj. SENSÍVEL

\begin{tabular}{|l|l|}
\hline SENSÍVEL: Temas e Figuras com a D.E & Temas e Figuras antes da D.E \\
\hline Aprendi o que é a D.E & Nem sabia o que era um Retiro \\
\hline $\begin{array}{l}\text { Diretor espiritual me orienta, dizendo o que é } \\
\text { correto, embasado na Doutrina Católica }\end{array}$ & Me chocava falar com o sacerdote \\
\hline $\begin{array}{l}\text { Visa além do nosso bem-estar também o bem- } \\
\text { estar do outro }\end{array}$ & \\
\hline $\begin{array}{l}\text { Orienta no que eu devo mudar. Ser mais positiva. } \\
\text { Olhar para frente }\end{array}$ & Sempre fui muito fatalista \\
\hline $\begin{array}{l}\text { Orientador coerente com a fé. Que não ponha } \\
\text { pano seco ou fique em cima do muro }\end{array}$ & Levava a vida no oba-oba. Faltava um \\
\hline $\begin{array}{l}\text { Aprendi amar a igreja, o Papa } \\
\text { Ver nas pessoas uma alma }\end{array}$ & Faltava um orientador espiritual \\
\hline $\begin{array}{l}\text { O espiritual é o sobrenatural. É um dom de Deus. } \\
\text { É conselho acertado... por experiência }\end{array}$ & \\
\hline $\begin{array}{l}\text { Na D.E é uma conversa entre eu e Deus , o } \\
\text { sacerdote é o intermediário }\end{array}$ & Me sentia desorientada \\
\hline $\begin{array}{l}\text { Ajuda a melhorar como pessoa. Crescer emvirtudes: } \\
\text { a ordem, paciência, a serenidade, a } \\
\text { caridade, falar mais baixo }\end{array}$ & Estava acomodada \\
\hline
\end{tabular}


Na D.E eu aprendi a ver além, ver a alma das

pessoas. No crescimento como pessoa

Não se consegue sozinho, mesmo os santos precisaramConheço pessoas que se afastaram da D.E, e

de diretores espirituais. É imprescindível. Você sabese afastaram de Deus. E quehoje são pessoas

que é um conselho

acertado

Você sai de lá aliviada depressivas

A D.E está ligada a Deus, à alma

Ajuda a crescer nas virtudes

Coloca o remédio certo na ferida. É médico de O psicólogo não está focado em Deus

almas. Tem o dom, uma vocação, para aproximarde

Deus

O próprio Cristo quando conversava com os

apóstolos, dava amor e direção espiritual

O adventista, luterano, eles não têm um

orientador espiritual, não têm um

embasamento

Orientação com visão sobrenatural. É diferente

Conheço pessoas que se afastaram, mas que

hoje são pessoas depressivas

Todos precisamos. Todos os santos tiveram

\subsubsection{Etapas da análise do discurso - Suj. Sensível}

A primeira fase da análise do discurso foi feita com a recomposição através de frases temáticas, sintetizando os temas e sub-temas do discurso na sua totalidade. A segunda fase, com a reflexão, procedemos o encadeamento e articulação entre os temas e as figuras, identificando congruências e/ou ambiguidades na fala dos enunciados.

As frases temáticas apuradas no discurso da Sensível são as seguintes: $1^{\mathrm{a}}$ ) Faço D.E há vinte anos.

$\left.2^{a}\right)$ Aprendi o que era a D.E.

$\left.3^{\mathrm{a}}\right)$ Me orienta, dizendo o que é correto, embasado na Doutrina Católica.4 ${ }^{\mathrm{a}}$ ) Visa além do meu bemestar também o bem-estar do outro.

$5^{\text {a) }}$ Orienta no que eu devo mudar. Ser mais positiva. Olhar para frente. $6^{\mathrm{a}}$ ) Aprendi amar a igreja e o Papa e foi me aproximando de Deus.

$\left.7^{\mathrm{a}}\right)$ Aprendi a ver a alma das pessoas.

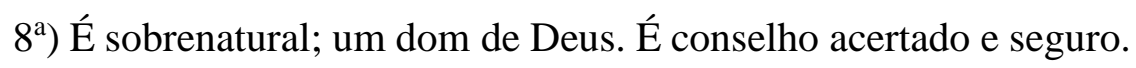

Classificação ; categorização das Frases Temáticas do sujeito:

- As frases $2^{\mathrm{a}}, 6^{\mathrm{a}}$ e $8^{\mathrm{a}}$ referem-se à capacidade de ajuda da D.E, no sentido de aproximar a pessoa de Deus.

- As frases $3^{\mathrm{a}}, 4^{\mathrm{a}}$ e $5^{\mathrm{a}}$ referem-se à habilidade da D.E, ajudando no discernimento, ponderação, maior facilidade e segurança com relação às tomadas de decisão.

- $\quad$ As frases $3^{\mathrm{a}}, 4^{\mathrm{a}}$ e $5^{\mathrm{a}}$ referem-se à capacidade de ajuda da D.E, para o desenvolvimento das virtudes. - As frases $3^{\mathrm{a}}, 4^{\mathrm{a}}, 5^{\mathrm{a}}$ e $7^{\mathrm{a}}$ referem-se à capacidade de ajuda da D.E, na administração de conflitos, nos relacionamentos, principalmente conjugal e educação dos filhos. Fomentando o progresso e o amadurecimento interpessoal. 
Concluindo-se a análise do discurso da Sensível, verifica-se que, com a ajudada D.E, hoje, ela se considera uma pessoa mais tranquila, segura e determinada. Afirma se sentir mais amadurecida e com a firme convicção de estar no caminho certo. Garante ter se tornado uma pessoa mais otimista e positiva, e que o diretor espiritual a ajudou muito no sentido de ser mais tolerante e paciente com as pessoas, o que contribuiu bastante no seu relacionamento conjugal e na educação dos filhos. Ela enfatiza que a direção espiritual a ajudou, principalmente, a aproximá-la da Igreja Católica, apesar de ter recebido uma educação Luterana.

\subsubsection{Análise do discurso - Suj. DEDICADA}

Identificação dos Temas e Figuras no discurso da Dedicada

Quadro 11 - Temas e figuras - Suj. DEDICADA

\begin{tabular}{|c|c|}
\hline DEDICADA: Temas e Figuras com a D.E & Temas e Figuras antes da D.E \\
\hline $\begin{array}{l}\text { Comecei por intermédio de uma amiga. Ela me } \\
\text { falava os benefícios da direção espiritual }\end{array}$ & $\begin{array}{l}\text { Eu achava que a vida das mulheres era } \\
\text { muito injusta, muito sofrida... }\end{array}$ \\
\hline $\begin{array}{l}\text { Chegando lá a irmã me recebeu e eu disse queera lá } \\
\text { que eu queria ficar }\end{array}$ & $\begin{array}{l}\text { Eu não entendia o que eu pensava.Naquele } \\
\text { momento eu não podia me } \\
\text { doar }\end{array}$ \\
\hline Eu perguntei para uma das irmãs o que era a D.E & $\begin{array}{l}\text { imaginava que deveria existir algo alémdo } \\
\text { confessionário }\end{array}$ \\
\hline $\begin{array}{l}\text { Depois eu entendi com mais profundidade. Aí } \\
\text { demorou muito para eu começar a fazer }\end{array}$ & $\begin{array}{l}\text { nunca ninguém me falou e eu não iria } \\
\text { perguntar }\end{array}$ \\
\hline $\begin{array}{l}\text { Tirei minhas dúvidas, dúvidas grandes que eu } \\
\text { tinha em relação ao perdão }\end{array}$ & $\begin{array}{l}\text { Faz uns oito anos que eu soube da } \\
\text { D.E no ambiente da PUC }\end{array}$ \\
\hline $\begin{array}{l}\text { Conversa, que durou } 40 \text { min., que não é osistema de } \\
\text { confissão, você vê tanto! }\end{array}$ & $\begin{array}{l}\text { Eu pensava como que eu vou lá falar } \\
\text { com o padre e não vou dar nada emtroca }\end{array}$ \\
\hline \multicolumn{2}{|l|}{ Fala tão completo, sobre a importância do perdão } \\
\hline $\begin{array}{l}\text { É uma pessoa que te explica, te tira dúvidas, } \\
\text { naquilo que você precisa corrigir }\end{array}$ & Me sentia desorientada \\
\hline \multicolumn{2}{|l|}{$\begin{array}{l}\text { Você sobe rapidamente vários degraus. Ele te } \\
\text { põe para pensar e te fala imediatamente }\end{array}$} \\
\hline \multicolumn{2}{|l|}{$\begin{array}{l}\text { Houve muitas mudanças. Hoje eu estou } \\
\text { enxergando o outro lado. Você começa enxergar } \\
\text { os teus próprios problemas }\end{array}$} \\
\hline $\begin{array}{l}\text { Me ajudou a ter mais tolerância e compreensão. } \\
\text { Eu sempre estou pronta para servir alguém }\end{array}$ & $\begin{array}{l}\text { Se você não reserva tempo para você, } \\
\text { você não se aprofunda e não cresce }\end{array}$ \\
\hline \multicolumn{2}{|l|}{$\begin{array}{l}\text { O diretor espiritual tem uma missão, não uma } \\
\text { profissão como o psicólogo. O único motivo paraele } \\
\text { não te atender é o tempo }\end{array}$} \\
\hline $\begin{array}{l}\text { Mais que fé, é certeza. Desde que tenham a } \\
\text { liberdade de querer }\end{array}$ & As vezes as pessoas não querem ajuda \\
\hline $\begin{array}{l}\text { Aprendi que eu não preciso responder pelos } \\
\text { problemas do mundo. E que as pessoas devem } \\
\text { se responsabilizar pela formação cristã }\end{array}$ & $\begin{array}{l}\text { Não conhecia a minha responsabilidadee o } \\
\text { alcance dos meus atos }\end{array}$ \\
\hline Eu demorei mas hoje eu encontrei meu caminho & $\begin{array}{l}\text { Existem muitos prejuízos numa D.E } \\
\text { inadequada }\end{array}$ \\
\hline
\end{tabular}




\subsubsection{Etapas da análise do discurso - Suj. Dedicada}

A primeira fase da análise do discurso foi feita com a recomposição através de frases temáticas, sintetizando os temas e sub-temas do discurso na sua totalidade. A segunda fase, com a reflexão, procedemos o encadeamento e articulação entre os temas e as figuras, identificando congruências e/ou ambiguidades na fala dos enunciados.

As frases temáticas apuradas no discurso da Dedicada, são as seguintes:

$1^{\text {a }) ~ F a c ̧ o ~ D . E ~ h a ́ ~ q u a s e ~ u m ~ a n o . ~ C o m e c e i ~ p o r ~ i n t e r m e ́ d i o ~ d e ~ u m a ~ a m i g a . ~ E l a ~ m e ~ f a l a v a ~ d o s ~ b e n e f i ́ c i o s ~}$ da D.E.

$\left.2^{\mathrm{a}}\right)$ Eu comecei a entender com mais profundidade e a sanar minhas dúvidas, principalmente em relação ao perdão.

$3^{\text {a }) ~ C o m e c e i ~ a ~ e n t e n d e r ~ p o r ~ o n d e ~ i r ~ e ~ a ~ a p r e n d e r ~ a ~ v e r ~ m a i s ~ l o n g e, ~ e n x e r g a n d o ~ u m ~ o u t r o ~ l a d o . ~}$

$4^{\mathrm{a}}$ ) O Diretor espiritual é uma pessoa que tira dúvidas, que explica, que te dirige onde você precisa se corrigir. Ele te põe para pensar. E você sobe rapidamente vários degraus.

$\left.5^{\mathrm{a}}\right) \mathrm{Me}$ ajudou a ter mais tolerância e compreensão. Eu sempre estou pronta para servir alguém.

$\left.6^{\mathrm{a}}\right)$ Ajuda a ter fé e certeza. Com liberdade. $7^{\mathrm{a}}$ ) Me ajudou com os problemas na família.

Classificação ; categorização das Frases Temáticas do sujeito:

- As frases $2^{\mathrm{a}}, 3^{\mathrm{a}}$ e $6^{\mathrm{a}}$ referem-se à capacidade de ajuda da D.E, no sentido de aproximar a pessoa de Deus.

- As frases $2^{\mathrm{a}}, 3^{\mathrm{a}}$ e $4^{\mathrm{a}}$ referem-se à capacidade de ajuda da D.E, proporcionando confiança e segurança.

- $\quad$ As frases $2^{\mathrm{a}}$, e $5^{\mathrm{a}}$ referem-se à capacidade de ajuda da D.E no equilíbrio emocional do sujeito.

- As frases $3^{\mathrm{a}}, 4^{\mathrm{a}}$ e $5^{\mathrm{a}}$ referem-se à influência positiva da D.E, ajudando nodiscernimento, ponderação e maior facilidade e segurança no processo de tomadas de decisão e administração dos conflitos.

- $\quad$ As frases $5^{\mathrm{a}}, 6^{\mathrm{a}} \mathrm{e} 7 \mathrm{a}$ referem-se à capacidade de ajuda da D.E, para o desenvolvimento das virtudes.

- As frases $4^{\mathrm{a}}, 5^{\mathrm{a}}$ e $7^{\mathrm{a}}$ referem-se à capacidade de ajuda nos relacionamentos (principalmente conjugal e educação dos filhos). Fomentando o progresso e o amadurecimento interpessoal do sujeito.

Concluindo-se a análise desse discurso, ficou evidenciado que a Dedicada, apesar de estar recebendo a sua direção espiritual por apenas um ano, considera esta prática fundamental para sanar suas dúvidas, para compreender o dinamismo do perdão e torna-se um instrumento para poder discernir e enxergar a realidade. Quanto ao diretor espiritual, a Dedicada, mostra no seu depoimento ter compreendido as principais funções do diretor como aquele que "ilumina" e ajuda a discernir. A relação aparece aqui mais equivalente aquele de um mestre com um discípulo no qual o importante é a transmissão de um aprendizado, ela diz: “o diretoré uma pessoa que tira dúvidas, explica, põe pra 
pensar, corrige". Ela sabe, porém, distinguir a direção espiritual tanto da consulta psicológica como da confissão. A vivência desta experiência para ela é relacional, dialógica, vem marcada pela funçãodo diretor de iluminar e fazer ver melhor o caminho de crescimento no Espírito, tal como afirma que foi “uma conversa que durou quarenta minutos, que não é o sistema de confissão, você vê tanto...". Além disso, apesar de pouco tempo de experiência na prática da direção espiritual, ela compreende a função do diretor/a desustentar e estimular o crescimento no espírito propondo ao dirigido o cultivo dos valores e virtudes, pois diz: "você sobe rapidamente vários degraus".

\subsubsection{Análise do discurso - Suj. LÚCIDA}

Identificação dos Temas e Figuras no discurso:

Quadro 12 - Temas e figuras - Suj. LÚCIDA

\begin{tabular}{|c|c|}
\hline LÚCIDA: Temas e Figuras com a D.E & Temas e Figuras antes da D.E \\
\hline $\begin{array}{l}\text { Comecei a conhecer a antropologia cristã, da alma } \\
\text { humana. Comecei a ter uma formação humana e } \\
\text { religiosa profunda e ampla }\end{array}$ & $\begin{array}{l}\text { Não somos bons conselheiros de nós } \\
\text { mesmos. Precisamos de uma visãoque } \\
\text { venha de fora }\end{array}$ \\
\hline \begin{tabular}{|lccccc} 
A D.E com o sacerdote tem um cunho \\
sobrenatural, transcendente. Há uma graça
\end{tabular} & Eu tinha muitas perguntas para fazer \\
\hline $\begin{array}{l}\text { A conversa é mais verdadeira, mais profunda, mais } \\
\text { realista e mais totalizadora }\end{array}$ & $\begin{array}{l}\text { Me sentia confusa. Não tinha certeza. } \\
\text { Não tinha o paradigmas }\end{array}$ \\
\hline $\begin{array}{l}\text { Tenho muita segurança ; Um sentido máximo na } \\
\text { minha vida ; Sensação de plenitude apesar dos } \\
\text { problemas }\end{array}$ & $\begin{array}{l}\text { Tinha medo do mundo. Não tinha } \\
\text { conceitos fortes; transcendentes }\end{array}$ \\
\hline Mais clareza e mais auto determinação & Ninguém me satisfazia \\
\hline $\begin{array}{l}\text { Hoje eu tenho condição de ter esses parâmetros } \\
\text { na minha vida. Me conheço mais }\end{array}$ & Não conhecia a D.E \\
\hline $\begin{array}{l}\text { Sei que eu sofro, eu sei meus pontos fortes e } \\
\text { minhas debilidades }\end{array}$ & Me interessava por verdades da fé \\
\hline $\begin{array}{l}\text { Com os conselhos, procuro viver ao máximo os } \\
\text { estudos humanos que percebo }\end{array}$ & $\begin{array}{l}\text { Meus comportamentos não eram } \\
\text { compatíveis com a minha idade }\end{array}$ \\
\hline \multicolumn{2}{|c|}{$\begin{array}{l}\text { Ajuda no plano de desenvolvimento espiritual para a|A necessidade da minha vocaçãopessoal } \\
\text { minha vida. Algo que acima do comer, dormir, trabalhar,latejava dentro de mim } \\
\text { filhos. Para desenvolver uma vocação. } \\
\text { Me encontrei ; adquiri mais plenitude }\end{array}$} \\
\hline $\begin{array}{l}\text { Mais feliz. Amadurecimento na vida transcendente } \\
\text { e na vida religiosa }\end{array}$ & Estava sem rumo \\
\hline \multicolumn{2}{|l|}{$\begin{array}{l}\text { Dá luz na saúde, profissão, casamento, ao meu } \\
\text { relacionamento social }\end{array}$} \\
\hline \multicolumn{2}{|l|}{$\begin{array}{l}\text { Hoje eu tenho mais segurança, domínio, autonomia } \\
\text { da própria vida, eu uso melhor a minha liberdade. } \\
\text { Pessoa adulta e responsável }\end{array}$} \\
\hline \multicolumn{2}{|l|}{ Sei para onde eu vou para atingir meu "gran finale" } \\
\hline Hoje me sinto satisfeita com a vida, mais forte & Eu estava muito frágil \\
\hline $\begin{array}{l}\text { O meu trabalho me satisfaz muito. Eu sei que } \\
\text { estou fazendo algo grande! }\end{array}$ & $\begin{array}{l}\text { Eu não estava com a minha identidade } \\
\text { formada apesar da minha idade }\end{array}$ \\
\hline $\begin{array}{l}\text { A D.E não trabalha apenas com o aspecto } \\
\text { espiritual, mas desenvolve as áreas humanas }\end{array}$ & \\
\hline
\end{tabular}




\subsubsection{Etapas da análise do discurso - Suj. Lúcida:}

A primeira fase da análise do discurso foi feita com a recomposição através de frases temáticas, sintetizando os temas e sub-temas do discurso na sua totalidade. A segunda fase, com a reflexão, procedemos o encadeamento e articulação entre os temas e as figuras, identificando congruências e/ou ambiguidades na fala dos enunciados.

As frases temáticas apuradas no discurso da Lúcida, são as seguintes:

$1^{\text {a }) ~ C o m e c e i ~ a ~ c o n h e c e r ~ a ~ a n t r o p o l o g i a ~ c r i s t a ̃, ~ d a ~ a l m a ~ h u m a n a . ~ C o m ~ u m a f o r m a c ̧ a ̃ o ~ h u m a n a ~ e ~}$ religiosa muito intensiva, profunda e ampla.

$\left.2^{\mathrm{a}}\right)$ A D.E tem um cunho sobrenatural, transcendente. Há uma graça.

$3^{\text {a) }}$ Tenho muita segurança. Um sentido máximo na minha vida. E umasensação de plenitude apesar dos problemas. Me sinto mais forte.

$4^{\mathrm{a}}$ ) Tenho mais clareza e mais auto-determinação. Me conheço mais.

$\left.5^{\mathrm{a}}\right) \quad$ Ajuda no plano de desenvolvimento espiritual, amadurecimento transcendente, desenvolvendo a minha vocação. Sou mais feliz.

$6^{\text {a) }}$ Dá luz, na saúde, na profissão, no casamento, no relacionamento social. $7^{\mathrm{a}}$ ) Hoje tenho mais segurança, domínio, autonomia da própria vida, usomelhor a liberdade. Sou uma pessoa adulta e responsável.

$8^{\mathrm{a}}$ ) Sei para onde vou, no "gran finale".

$\left.9^{a}\right)$ O meu trabalho me satisfaz muito. Sei que estou fazendo algo grande.

Classificação e categorização das Frases Temáticas da Lúcida:

- As frases $1^{\mathrm{a}}, 2^{\mathrm{a}}, 5^{\mathrm{a}}$ e $8^{\mathrm{a}}$ referem-se à capacidade de ajuda da D.E, no sentido de aproximar o sujeito de Deus, ajudando-a a descobrir a sua vocação pessoal e o sentido último da vida.

- As frases $3^{\mathrm{a}}, 5^{\mathrm{a}}, 6^{\mathrm{a}}, 7^{\mathrm{a}}$ e $8^{\mathrm{a}}$ referem-se à capacidade de ajuda da D.E, proporcionando confiança, segurança e paz ao sujeito.

- As frases $3^{\mathrm{a}}, 5^{\mathrm{a}}, 7^{\mathrm{a}}, 8^{\mathrm{a}}$ e $9^{\mathrm{a}}$ referem-se à influência positiva da D.E no equilíbrio emocional e na qualidade de vida do sujeito.

- As frases $1^{\mathrm{a}}, 3^{\mathrm{a}}, 4^{\mathrm{a}}, 6^{\mathrm{a}}$ e $7^{\mathrm{a}}$ referem-se à capacidade da D.E, ajudando nodiscernimento, ponderação, maior facilidade e segurança com relação às tomadas de decisão na vida do sujeito.

- As frases $1^{\mathrm{a}}, 3^{\mathrm{a}}, 4^{\mathrm{a}}, 5^{\mathrm{a}}, 6^{\mathrm{a}}, 7^{\mathrm{a}}$ e $9^{\mathrm{a}}$ referem-se à capacidade de ajuda da D.E, no desenvolvimento das virtudes; na realização pessoal e profissional; conduzindo no sentido do exercício da liberdade ${ }^{52}$ com diligencia e responsabilidade.

- As frases $1^{\mathrm{a}}, 3^{\mathrm{a}}, 4^{\mathrm{a}}$ e $6^{\mathrm{a}}$ referem-se à capacidade de ajuda da D.E, na administração de conflitos, nos relacionamentos, principalmente no conjugal e na educação dos filhos. Fomentando o progresso e 
o amadurecimento interpessoal.

Com a conclusão da análise desse último discurso, verifica-se que, com a ajuda da direção espiritual, a Lúcida se sente uma pessoa mais madura, segura e equilibrada emocionalmente. Apresentando-se de uma maneira geral mais tranquila,prudente e forte; mais justa, generosa, dócil e compreensiva no trato com os outros; mais habilidosa na administração de conflitos; com mais segurança no processo de tomada de decisão; mais ponderada e coerente com o seu plano de vida; e, principalmente, mais confiante e próxima de Deus. Afirmando ter se tornado com a ajuda da direção espiritual, uma pessoa com "autodomínio e autonomia da própria vida"; alegando se sentir "uma pessoa adulta e responsável", que "sabe usar melhor a sua liberdade", plenamente consciente do sentido da sua vida.

\section{REFLEXÃO E DISCUSSÃO DOS RESULTADOS}

O resultado geral da análise dos discursos das nove mulheres investigadas, demonstra que os sujeitos, a partir do momento que passaram a receber a orientação de um diretor/diretora espiritual, declaram terem se tornado pessoas, de uma maneira geral, mais maduras e emocionalmente mais equilibradas. Ficando evidenciado que a direção espiritual regular oferece alguns benefícios concretos que ajudam a incrementar a qualidade de vida das pessoas que recebem a orientação e, ao mesmo tempo, tem um reflexo positivo também na vida de outras pessoas, principalmente marido, filhos e os parentes mais próximos.

A partir da análise dos discursos de cada uma das entrevistadas, foram apurados sete temas gerais - interligados e coesos -, identificados em todos os depoimentos analisados. São temas-chave que sintetizam as perguntas das entrevistas e, ao mesmo tempo, permitem elucidar alguns objetivos da própriapesquisa. Por outro lado, fica evidente que a tarefa de compreender todas as questões referentes ao significado da direção espiritual e a sua relação com o desenvolvimento de uma personalidade mais integrada e madura, ainda não está terminada. Nos depoimentos dessas nove mulheres, por sua vez, encontra-se fragmentos de todos os elementos que são destacados pela tradição da Igreja - conforme assinalado no percurso histórico nesta pesquisa - como fundamentais tanto no exercício por parte do diretor/a nas funções de acolher/escutar,iluminar/discernir, sustentar e estimular o desenvolvimento pessoal e o crescimento na vida espiritual, quanto por parte do dirigido/a em assumir atitudes de confiança, abertura e sincera busca de um caminho espiritual.

A tentativa de discriminar dois níveis de experiências, a saber, a psicológica ea ôntica, seguiu as indicações de Safra (2001) e de Frankl (1982), para os quais a experiência psicológica se refere àquele fluxo dos desejos, das representações, dasfantasias e dos impulsos; enquanto o nível ôntico é o campo das vivências espirituais e das experiências místicas. Segundo Safra, estas últimas: 
São vivências que ocorrem sem o condicionamento ao processo de desenvolvimento do ser humano, aparecendo independentemente daidade daquele que as experimenta. Elas penetram na vida como horizonte de sentido, arrebatam e abrem o indivíduo à esperança e transcendência (SAFRA, 2001, p. 54).

As frases temáticas apuradas nos discursos de todos os sujeitos, com relação às suas experiências com a direção espiritual, foram as seguintes:

$1^{\text {a) }}$ Me faz bem.

$2^{\text {a) }}$ Me sinto mais forte e dá segurança.

$3^{\mathrm{a})}$ Me ajuda na aquisição de virtudes importantes.4 ${ }^{\mathrm{a}}$ ) Me conheço melhor.

$5^{\text {a) }}$ Me orienta e encaminha respeitando a minha liberdade.

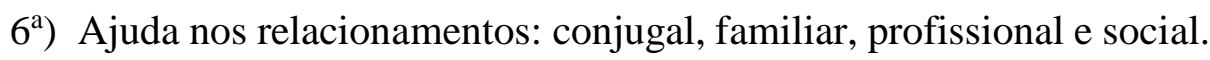

$7^{\text {a) }}$ Tem um cunho sobrenatural - contribui aprimorando o sentimento defiliação divina e a descoberta do sentido da vida.

Classificação / categorização das frases temáticas dos nove discursos analisados:

- As frases $1^{\mathrm{a}}, 2^{\mathrm{a}}, 3^{\mathrm{a}}, 4^{\mathrm{a}}$ e $5^{\mathrm{a}}$ referem-se à influência positiva da direção espiritual no equilíbrio emocional e na qualidade de vida dos sujeitos.

- As frases $2^{\mathrm{a}}, 3^{\mathrm{a}}, 4^{\mathrm{a}}, 5^{\mathrm{a}}$ e $6^{\mathrm{a}}$ referem-se a influência da direção espiritual, ajudando no discernimento, ponderação, maior facilidade e segurança com relação às tomadas de decisão e administração de $\operatorname{conflitos}^{53}$.

- As frases $2^{\mathrm{a}}, 3^{\mathrm{a}}, 4^{\mathrm{a}}, 5^{\mathrm{a}}$ e $6^{\mathrm{a}}$ referem-se à capacidade de ajuda da direção espiritual,como guia: na aquisição e desenvolvimento das virtudes; na realização pessoal e profissional; fomentando o exercício da liberdade com responsabilidade.

- A $7^{\text {a }}$ frase refere-se à capacidade de ajuda efetiva da direção espiritual, no sentido de aproximar a pessoa de Deus e, ao mesmo tempo, orientando na descoberta da vocação pessoal e o sentido da vida.

Contudo, o resultado final da análise dos nove discursos examinados evidencia que essas mulheres, acompanhadas regularmente por um diretor/a espiritual, se consideram, em todos os casos analisados, pessoas mais realizadase, de uma maneira geral, mais felizes. Na primeira parte da análise dos discursos - identificação de temas e figuras - pôde-se evidenciar a satisfação dos sujeitos com relação aos seus respectivos diretores/as espirituais. Algumas declararam sentir "segurança" na direção espiritual devido a formação e seriedade do seu diretor/a espiritual. Pode-se verificar isso, por exemplo, no modo como o sujeito Esforçada se refere ao diretor espiritual: "O Diretor pode ser um sacerdote ou uma pessoa leiga, desde que tenha formação pra isso, ou seja, viver as virtudes e ter atitudes corretas 
e, especialmente, ter a graça de Deus". No mesmo depoimento ela alega que se sentia perdida, mas não queria "abrir-se para qualquer pessoa".

O estudioso Mario Aletti, nesse sentido, sublinha a importância da formação dos diretores/as espirituais, estabelecendo um paralelo com os psicoterapeutas, os quais, ao longo de um largo período de formação, mediante acompanhamento e supervisão, são treinados nos minuciosos procedimentos de avaliação e diagnóstico e, ao mesmo tempo, conscientizados acerca das inúmeras técnicas e intervençõesterapêuticas em psicoterapia.

Estou convencido de que também as pessoas que oferecem acompanhamento espiritual deveriam ser preparadas com um bom conhecimento não só de si, mas também de si como sujeito de uma relação e, em geral, das próprias competências de comunicação. Daínasce uma questão, que abro com interrogações: quem forma os formadores religiosos? De onde surgem os diretores espirituais dos seminários? Por meio de quais experiências, percursos, verificações de requisitos ou designações? Como floresce e amadurece a capacidade de maternidade-paternidade de um abade, de uma madre abadessa?” (ALETTI, 2008, p. 123).

Aqui Aletti (2008), chama a atenção para algumas questões importantes que devem ser consideradas na formação dos diretores/as espirituais. Especialmente, quando se trata de direção espiritual para mulheres. Quem orienta, segundo ele, deve estar consciente das peculiaridades da espiritualidade feminina.

Diferente do homem, a mulher desenvolve-se espiritualmente quando sedeixa levar pela sua tendência natural para a maternidade, ou seja, atende o seu impulso instintivo feminino de servir como mãe. E essa inclinação maternal, inerenteà natureza feminina, vai muito além do fato de se gerar um filho. O verdadeiro sentido da maternidade está na responsabilidade de cuidar, sustentar, proteger e encaminhar amorosamente outro ser humano. E essa tarefa acontece também no aspecto espiritual. Quando uma mulher cuida de seus filhos (não necessariamente biológicos), os atendendo, orientando e encaminhando, também exerce a sua maternidade, mas em um sentido transcendente. E, de uma maneira ou de outra, é também disso que se trata a direção espiritual: cuidar e encaminhar o outro com a luz do Evangelho e as inspirações do Espírito Santo. Como uma criança pequena que ainda não sabe andar e sua mãe a ampara, orienta e protege, até que ela seja capaz de caminhar sozinha.

\section{CONCLUSÃO}

Um homem pode ser sagaz e mestre de muitos, mas para si próprio é inútil (Ecl 37, 19)

A Igreja Católica, por meio do magistério pastoral, ao recomendar a prática da direção espiritual aos seus fiéis entende oferecer um serviço para ajudar e iluminara pessoa no caminho humano do espírito e no progresso do seguimento de Jesus Cristo. Pode-se recordar, neste sentido, as palavras do 
Papa Bento XVI: "Como sempre tem feito, a Igreja continua recomendando a prática da direção espiritual não só aos que desejem seguir Cristo de perto, mas a todo cristão que quer viver com responsabilidade o próprio Batismo",54. Desse modo, a direção efetiva, supõe uma mediação, a ajuda de uma pessoa a outra na tentativa de discernir as principais moções do Espírito ao fiel que tem a missão de assumir o compromisso batismal.

$\mathrm{Na}$ verdade, vivemos hoje uma época conturbada e com muitas incertezas, onde uma grande parte das pessoas não se sente segura e não sabe onde se amparar, por isso, explicitar a forma como algumas mulheres consideraram a práticada direção espiritual como um bem para o progresso humano e espiritual, parece ser a principal contribuição do presente trabalho.

Os resultados desta pesquisa evidenciam que as pessoas - representadas pelos sujeitos investigados -, estão necessitadas de ajuda, de orientação e de amparo. E, o que parece mais preocupante, é que a privação dessas necessidades pode levar alguns indivíduos a se sentirem angustiados e abatidos, podendo inclusive, culminar em depressão. Esse sentimento, como todas as outras manifestações de insegurança, surge quando a pessoa não encontra os elementos necessários para defender a sua frágil vulnerabilidade.

Nesse sentido, a investigação fenomenológica atual vem, pouco a pouco, revelando que essa ansiedade e angústia aparecem onde falta o sentimento ou a experiência do que os alemães chamam Geborgenheit, e o que Torelló (1987) traduz como amparo afetivo - sentimento que experimentamos quando vivemos dentro de um ambiente familiar saudável.

No entanto, o pai e a mãe que nos dão a vida e nos resguardam no ambiente familiar, poucas vezes têm o poder de nos defender dos perigos que se encontram no universo hostil de alguns ambientes sociais. Para que esse amparo afetivo nos envolva, como uma grande cúpula protetora, ele tem que ser infinitamente amplo e abrangente. E o que o resultado desta pesquisa revela é que essa sensação de conforto e segurança é, justamente, o que a Igreja Católica vem oferecendo na direção espiritual.

Os depoimentos dos sujeitos investigados, de uma maneira geral, evidenciamque a direção espiritual presta esse tipo de orientação, proporcionando uma sensação de amparo e segurança a quem busca essa assistência. Constata-se, por exemplo, no discurso do sujeito Delicada (Anexo), que a direção espiritual representa uma ajuda efetiva, percebida em diversos âmbitos: “ajuda a ver a etapa em que se está na vida espiritual [...] ajuda nas dificuldades [...] ajuda na confiançae abertura a Deus [...] ajuda na caminhada mais concreta e efetiva [...] ajuda a entender o que Deus quer de mim". A mesma Delicada continua, declarando que, com a assistência do diretor espiritual, ela se sente "mais segura, mais confiante e mais tranquila". Bastante diferente de como ela se sentia antes de receber essa orientação. 
Verifica-se também, que direção espiritual tem sido importante na vida dessas mulheres no sentido de oferecer apoio e estabilidade emocional, ajudando a manter o equilíbrio e qualidade nos relacionamentos, tanto familiar como social e profissional. No seu discurso a Serena (Anexo) alega: "com a direção espiritual aprendi a aceitar as pessoas como elas são, com amor, paciência e humildade".

Segundo o depoimento da Tímida (Anexo): "a direção espiritual esclarece as minhas dúvidas; me dá fortaleza, paz, certeza e confiança de estar no caminho certo". Encontramos essa mesma sensação no discurso da Serena: "a direção espiritual me dá tudo!: segurança, me sinto forte, compreendida e amparada".

A Singela (Anexo), compara a direção espiritual a "uma faxina, uma higienização. Me faz bem, me deixa mais leve, mais limpa, como depois do banho". Já para a Tímida a direção espiritual "é como um alimento. Me faz falta [...] quando não consigo ir à direção, me sinto fraca".

Ficou claro também, que para todas essas mulheres, o diretor espiritual representa, um “instrumento de Deus", segundo as palavras da Singela (Anexo) "eleme acalma e tranquiliza [...], me dá equilíbrio". Dessa mesma forma, ao longo do depoimento da Lúcida (Anexo), ela declara: "Hoje me sinto satisfeita com a vida,uma pessoa mais forte [...] antes da direção espiritual, eu me sentia muito frágil,uma pessoa sem rumo [...] hoje eu me sinto amparada".

Essa sensação de segurança e conforto, esse amparo afetivo proporcionado com a prática da direção espiritual, foi efetivamente verificado em todos os nove depoimentos analisados durante a pesquisa.

Quando se acredita que Deus é Pai, um Pai amoroso e zeloso, que ama seusfilhos muito mais do que podem amar todos os pais e todas as mães do mundo juntos, experimenta-se realmente um sentimento íntimo de amparo e segurança de grandes dimensões. Quando a fé passa da cabeça para o coração, da psique para osoma, o corpo e a alma experimentam uma paz que ultrapassa todo o entendimentohumano.

Quando a palavra do Senhor que diz: "No mundo haveis de ter tribulações, mas tende coragem!" (Jo 16,33), penetra profundamente na nossa vida, invade-nos uma segurança inabalável, mudam todas as nossas perspectivas e podemos sentir uma paz e uma serenidade profunda, que não se consegue alcançar com nenhum artifício farmacológico de última geração.

Essa confiança, esse otimismo, esse equilíbrio e harmonia íntima, são as características que formam parte de uma personalidade cristã amadurecida e é, basicamente, o que se deseja alcançar com a ajuda da direção espiritual.

Finalmente, de tudo o que foi apresentado, ficou evidenciado portanto, que o caminho teóricometodológico percorrido na busca de respostas às perguntas de pesquisa, conduziu ao esperado encontro com a realidade e fez vislumbrar horizontes e possibilidades além das expectativas do início 
do trabalho. Tudo issofoi possibilitado pelo minucioso cuidado e o rigor empregado nos procedimentos e metodologia de pesquisa, ferramentas essenciais diante dos complexos temas envolvidos nessa investigação.

Pretendeu-se contudo, desde o início, apresentar-se os benefícios a longo ea curto prazo, concretos e práticos, que podem ser alcançados com a direção espiritual frequente. E, especialmente, oferecer parâmetros para se buscar um diretor espiritual autêntico, uma pessoa de confiança, bem formada e capacitada para orientar e guiar as pessoas nos verdadeiros caminhos que levam à Deus.

Este é o ponto em que está baseada a direção espiritual: através do diretor/a espiritual, somos lembrados de uma maneira simples, prática e definitiva, o que Deus espera de seus filhos: "Apenas que o temas e andes em seus caminhos; que ames e sirvas ao Senhor teu Deus com todo o teu coração e com toda a tua alma, eque observes os mandamentos ${ }^{55}$ do Senhor" (Dt 10, 12-13).

Assim, a nossa sensibilidade vai se aprimorando, o nosso conhecimento da realidade se aprofunda, os meios à nossa disposição se multiplicam, e a nossa confiança se fortalece. E, sobretudo, na direção espiritual, somos lembrados que podemos contar sempre com a graça e a misericórdia do Pai, confiantes no Omniain bonun, com a total segurança de "que tudo contribui para o bem daqueles que amam a Deus" (Rm 8, 28). 


\section{REFERÊNCIAS}

ADLER, A., The Individual Psychology of Alfred Adler. H. L. Ansbacher and R. R. Ansbacher (Eds.). New York: Harper Torchbooks, 1956.

AlVAREZ, T., OBRAS COMPLETAS de Teresa de Jesus, São Paulo: Loyola,1995.

AMATUZZI, M., Experiência Religiosa, Psicoterapia e Orientação Espiritual. In:SAVIO, A., et al., Religiosidade e Psicoterapia. São Paulo: ROCA, 2008.

AQUINO, São Tomás, SUMA TEOLÓGICA. Edição dirigida por los Regentes deEstudios de las Provincias Dominicanas en España, Madrid: B.A.C., 2001.

AYLLÓN, J., Luces en la caverna. Barcelona: M. Roca, 2001.

BAKHTIN, M., Marxismo e filosofia da linguagem. São Paulo: Hucitec, 1995. BENTO, São, A Regra. Trad. Dom Basílio Penido, OSB. Petrópolis: Vozes, 1992.

BERNAL, S., Mons. Josemaría Escrivá de Balaguer: apuntes sobre la vida delfundador del Opus Dei. Madrid: Rialp, 1980.

CABANELlAS, G., Diccionario Enciclopédico de Derecho Usual, Vol. V. BuenosAires: Editorial Heliasta, 1996.

CAR, M.R.; BERTOLOZZI, M.R ., O procedimento da análise de discurso. In: ABEN - Associação Brasileira de Enfermagem. Brasília: Aben, 1999.

CASSIANO, J., Conferências I-VII, Vol. 1. Trad.: Aída Batista do Val. Juiz de Fora:Mosteiro de Santa Cruz, 2003.

Santa Cruz, 2006.

Conferências VIII-XV, Vol. 2. Trad.: Aída Batista do Val. Juiz de Fora:Mosteiro de

DARWIN, C., A Expressão das emoções no homem e nos animais. São Paulo:Companhia das Letras, 2000.

DÍEZ-RAMOS, Pe., Obras completas de San Bernardo, Vol. I. Madrid: B.A.C,1953.

EKMAN, P., Darwin and Facial Expression: A Century of Research and Review.New York: Major Books, 2006.

ESCRIVÁ, J., É Cristo que Passa, 2a ed. São Paulo: Quadrante,Trad. coordenadae revista por Emérico da Gama, 1975.

, Amigos de Deus. São Paulo: Quadrante, 1977.

, Questões atuais do Cristianismo, 3ª ed. São Paulo: Quadrante,1986.

, Caminho, 9a ed. São Paulo: Quadrante, 1999.

FERNÁNDEZ-CARVAJAL, F., La dirección espiritual. Madrid: Palabra, 2003. 
Para llegar a puerto. El sentido de la ajuda espiritual. Madrid:Palabra,

2011.

FIORIN, J.L., Linguagem e ideologia. São Paulo: Ática, 1988.

, Elementos de análise do discurso. São Paulo: Edusp, 1989.

FIORIN J.L.; SAVIOLI F.P., Para entender o texto: leitura e redação. São Paulo:Ática, 1991.

FORSTER, E.M., The E.M. Forster Collection: 11 Novels and Short Stories(Halcyon Classics). New York: Kindle Edition, 2009.

FRANKL, V.E., Teoría y terapia de las neurosis. Madrid: Gredos, 1964.

, Psicoterapia y humanismo. México: F. C. E., 1982.

, La voluntad de sentido. Barcelona: Herder, 1988.

, Psicoterapia y Existencialismo, $3^{\text {a }}$ Ed., Barcelona: Herder, 2003.

, Man's Search for Meaning, 5ª Ed. Boston: Beacon Press, 2006. FREIRE, J.B., Acerca del hombre en Viktor Frankl. Barcelona: Herder, 2002a.

, El Humanismo de la Logoterapia de Viktor Frankl. Pamplona:Eunsa, 2002b.

FREUD, S., El porvenir de una ilusión. Barcelona: Orbis, 1983. GARRIDO, J., Releitura de São João da Cruz. São Paulo: Paulinas, 2010.

GARRIGOU-LAGRANGE, R., Las Tres Edades de la Vida Interior. Madrid:Palabra,1999.

GEBSATTEL, F.V, La compreensión del hombre desde una perspectivacristiana. Madrid: Rialp, 1966.

GOMÉZ-PERÉZ, R., Problemas morais da existência humana. Lisboa: CAS,1980.

HAMMERSLEY, M., ATKINSON, P., Ethnography: principles in practice.

Londres: Tavistock, 1983.

ISAACS, D., La educación de las virtudes humanas. Navarra: EUSA, 1996.JAEGER, W., Los ideales de la cultura griega. México: FCE, 1971.

JESUS, Santa Teresa do Menino, História de uma alma, 26 a ed. Trad.: Religiosa do Carmelo do Imaculado Coração de Maria e de Santa Terezinha. São Paulo: Paulus, 2008.

KÜNKEL, F., Fritz Kunkel: Selected Writings. John A. Sanford ed., intro., \& commentary. NJ: Paulist, 1984.

LANE, S.T.M., Linguagem, pensamento e representações sociais, In: LANE, S.T.M.; CODO, W., Psicologia social: homem em movimento, $2^{\mathrm{a}}$ ed. São Paulo: Brasiliense, 1985.

LEÓN XIII, La practica de la humildad. Trad.: Sanabria Martín. Madrid: Rialp,2007.

LEWIS, C.S., The Problem of Pain. New York: HarperCollins Publishers, 2001. 
LOYOLA, Santo Inácio, Exercícios Espirituais de Santo Inácio de Loyola. $7^{\mathrm{a}}$ ed.São Paulo: Loyola, 2004.

LUCIANI, A., Ilustríssimos Senhores. São Paulo: Loyola, 1979. MARX K.; ENGELS F., Ideologia Alemã. São Paulo: Hucitec, 1984.

MINAYO, M.C.S., Pesquisa social: teoria, método e criatividade. 14 ${ }^{\mathrm{a}}$ ed.Petrópolis: Vozes, 1992.

MÜLlER, B., Opus Dei, Suíça, 1954. Trad.: Guilherme Döring Cunha Pereira,Edição: Escritório de Informação da Prelazia do Opus Dei no Brasil, 2004.

PARSE, R. R., COYNE, A. B., \& SMITH, M. J., Nursing research: Qualitativemethods. Bowie, MD: Brady, 1985.

PETER, E., Ari: The Life and Times of Aristotle Onassis. New York: SummitBooks, 1986.

PlATÃO, A República, 2a ed., Trad.: Pietro Nassetti. São Paulo: Martin Claret,2000.

POLAINO-LORENTE, A., Madurez personal y Amor conyugal. Madrid: Rialp,1995.

PRADA, A. V., O fundador do Opus Dei. Vol. I. Trad.: Emérico da Gama. SãoPaulo: Quadrante, 2004.

RICHARDSON, R.J., Pesquisa Social, métodos e técnicas. São Paulo: Atlas,2010.

ROYO-MARÍN, A., Los grandes maestros de La vida espiritual, 2a ed. Madrid:B.A.C, 1990. , Teologia de la perfección Cristiana, 7ª ed. Madrid: B.A.C, 1994.

SAFRA, G. Reflexões a partir de Esboços de teoria do desenvolvimento religioso de Amatuzzi In: PAIVA, J.G. (org.), Entre necessidade e desejo: diálogos da psicologia com a religião. São Paulo: Loyola, 2001.

SALES, San Francisco, Introducción a la vida devota. Madrid: Palabra, 2006.

SCHELER, M., El puesto del hombre en el cosmos, $5^{\text {a }}$ ed. Buenos Aires: Losada, 1964.

SCHRADER, A., Introdução á pesquisa social empírica. Porto Alegre: Globo, 1974.

SENA, Santa Catarina, Cartas completas. Trad.: João Alves Basílio. São Paulo: Paulus, 2005.

SESÉ, J., Historia de la espiritualidad. Pamplona: Eunsa, 2005.

SOUZA, S.F., Em busca do amor que completa sem acabar. Curitiba: Ed. IEF,2010.

SPINELli, M., Helenização e Recriação de Sentidos. A Filosofia na época da expansão do Cristianismo - Séculos, II, III e IV. Porto Alegre: Edipucrs, 2002 
STINISSEN, W., Una noche clara como el día. Burgos: Ed. Monte Carmelo, 2010.SUÁREZ, F., A Virgem Nossa Senhora. Lisboa: Prumo-Rei dos Livros, 1983.

TANQUEREY, A., Compêndio de Teologia Ascética e Mística, Porto: Livraria Apostolado da Imprensa, 1961.

TORELLÓ, J.B., Psicologia aberta, São Paulo: Quadrante, 1987.

VÁZQUES DE PRADA, A., O fundador do Opus Dei, Vol. I. Trad.: Emérico daGama. São Paulo: Quadrante, 2004.

YEPES, R; ARANGUREN, J., Fundamentos de Antropologia. Pamplona: EUNSA,1999.

WOJTYLA, K., Persona y acción. Madrid: B.A.C, 1982.

ZAMBONINI, F. Chiara Lubich, a sua herança. São Paulo: Paulinas, 2010.

OUTRAS FONTES REFERENCIADAS:

BÍBLIA DE JERUSALÉM. São Paulo: Edições Paulinas, 1989.

CATECISMO DA IGREJA CATÓLICA. Edição Latina: Vozes, Paulinas, Loyola eAve-Maria, 1993.

DICIONÁRIO DE ESPIRITUALIDADE. Org.: FIORES, S.; GOFFI, T. São Paulo: Paulinas, 1989.

DICCIONARIO DE ESPIRITUALIDAD. Org.: ANCILLI, E. Barcelona: Herder, 1987.

DOCUMENTOS DO CONCÍLIO ECUMÊNICO VATICANO II - XXI Concílio Ecumênico da Igreja Católica. Documentos conciliares e pontifícios (1962-1965).São Paulo: Paulus, 1997.

ORAÇÕES DO CRISTÃO, Coletânea, 8ª ed. São Paulo: Quadrante, 2001.

Encíclicas e documentos papais impressos:

IGREJA CATÓLICA. Papa (1810-1903: Leão XIII ). Carta ao Cardeal JamesGibbons, Testem benevolentiae, 22-I-1899. Rio de Janeiro: Vozes, 1984.

IGREJA CATÓLICA. Papa (1876-1958: Pio XII). Exortação Apostólica Mentinostrae, 23-IX1950. Rio de Janeiro: Vozes, 1984.

IGREJA CATÓLICA. Papa (1978-2005: João Paulo II). Exortação Apostólica Pastores dado vobis, 25-III-1992. Rio de Janeiro: Vozes, 2010. 
IGREJA CATÓLICA. Papa (2005- : Bento XVI). Carta Encíclica Spe salvi, 30-XI-2007. Rio de Janeiro: Vozes, 2010.

Encíclicas e documentos papais disponíveis on-line:

IGREJA CATÓLICA. Papa (1897- 1978: Paulo VI). Homilia da Missa do Doutorado de Santa Teresa, em 27-IX-1970 (http://www.zenit.org/). Acessado em 02 de maio, 2011.

IGREJA CATÓLICA. Papa (2005- : Bento XVI). Homilia da Missa Inaugural do Pontificado do Papa Bento XVI, em 2004-04-17 (http://www.zenit.org/). Acessado em 13 de junho, 2011.

IGREJA CATÓLICA. Papa (2005- : Bento XVI).Discurso comemorativo aos 75 anos de fundação da Faculdade Pontifícia Teresianum de Roma, em 19 de maio de 2011 (http://www.zenit.org/). Acessado em 21 de junho, 2011.

IGREJA CATÓLICA: Documento Oficial: La preparazione al sacerdozio ministeriale(Preparação para as diretrizes do sacerdócio ministerial e normas). Disponível em: http://translate.googleusercontent.com/translate_c?client=tmpg\&hl=en\&langpair=it|pt\&rurl=tr anslate.google.com\&u=http://www.vocazioni.net/index.php\%3Foption\%3Dcom_content\%26 view\%3Darticle\%26id\%3D733:preparazione-al-sacerdozio\%26catid\%3D42:documenti-cei- sullevocazioni\%26Itemid\%3D286\&usg=ALkJrhgsa_SlzRoDDXt3wMhF7dytWNh80g. Acessado em 26 de julho, 2011.

\section{Artigos citados}

ALETTI, M. Atendimento psicológico e direção espiritual: semelhanças, diferenças, integrações e... confusões. Psicologia:Teoria e Pesquisa, v. 24, n. 1, pp. 117-126, 2008.

CAREGnATO, R.C.A., Pesquisa qualitativa: análise de discurso versus análise de conteúdo. Artigo produzido como trabalho de conclusão da disciplina ministrada pela Professora Regina Mutti, do Programa de Pós-Graduação em Educação (FACED) da Universidade Federal do Rio Grande do Sul (UFRGS). Publicação: Texto Contexto Enferm. Florianópolis, 2006 Out-Dez; 15(4): 679-84.

HOLANDA, A.F. Questões sobre Pesquisa Qualitativa e Pesquisa Fenomenológica. Análise Psicológica (Lisboa), v. 24, n. 3, p. 363-372, 2006. Disponível na World Wide Web em: http://www.scielo.oces.mctes.pt/pdf/aps/v24n3/v24n3a10.pdf

RUIZ, R., Hamlet: ação e decisão. Publicado no site da Editora Quadrante, em 13 de maio, 2006.

SABBATINI, R., The Evolution of Human Intelligence. Publicado Revista Brain \& Mind Magazine. Nova York, 12 February-May, p. 79, 2001.

SOUZA, R.M, A direção espiritual católica, seu poder subjetivante e influência no desenvolvimento da espiritualidade feminina. Publicado no III Congresso Nacional ANPTECRE. São Paulo, 2011. ISBN 9788561859985. 
TORELLÓ, J.B., La espiritualidad de los laicos. Publicado Revista Nuestro Tiempo. Pamplona, n. 127, p. 77, 1965.

URFER, A., Phenomenology and Psychopathology of Schizophrenia: The Views of Eugene Minkowski. Published: Philosophy, Psychiatry, \& Psychology, Vol. 8, n. 4, December 2001, DOI: 10.1353/ppp.2002.0029.

\section{Fontes complementares de referências on line}

http://www.grupopentecostes.com/?opcao=ver_formacao\&codigo=\%2012. Acessado em 05 Abril, 2011.

http://psicologiacademica.blogspot.com/2010/05/dicionario-de-psicologiad.html. Acessado em 10 Abril, 2011.

http://www.slideshare.net/jegonzal/siete-pecados-y-virtudes-capitales. Acessado em17 Abril, 2011.

http://www.youtube.com/watch?v=N7tGsbCu2II. Acessado em 21 de junho, 2011. http://pt.wikipedia.org/wiki/Movimento_dos_Focolares. Acesso em 20 Junho, 2011. http://www.zenit.org/article-17876?l=portuguese. Acessado em 20 Junho, 2011.

http://www.zenit.org/. Acessado em 25 Junho, 2011.

http://ec.aciprensa.com/wiki/Cura_de_almas. Enciclopédia Católica on line: Acessado em 18 Julho, 2011.

http://gloria.tv/?media=158654\&connection=dialup. Acessado em 02 Agosto, 2011. 


\section{APÊNDICE}

Roteiro para as entrevistas

\section{Roteiro para entrevista individual sobre a experiência na DIREÇÃO ESPIRITUAL}

PERGUNTAS semi-estruturadas (Intercalando-se abertas e fechadas):

1a) Há quanto tempo ve faz D.E?

(Pergunta fechada $\square$ Para verificar o nível de comprometimento do sujeito) 2a) Como vc começou a fazer D.E?

(Pergunta aberta $\square$ para verificar a motivação inicial do sujeito)

3) Como ve se sentia antes da D.E?

(Pergunta aberta $\square$ para verificar o progresso do sujeito com a D.E)

4) Como ve se sente hoje?

(Pergunta aberta $\square$ para verificar o progresso do sujeito com a D.E)

5) O que mudou na sua vida a partir desses atendimentos?

(Pergunta aberta $\square$ para verificar a influência da D.E na vida do sujeito)

6) Qual o significado da D.E. na sua vida hoje?

(Pergunta aberta $\square$ para verificar o que a D.E representa na vida do sujeito)

7) Vc recomendaria a D.E? Como?

(Pergunta dupla $\square$ para verificar como o sujeito considera a D.E, em geral) 
ANEXO

Entrevistas gravadas na íntegra(arquivo em audio amr.) 